Ingela Helmfrid

\title{
Exposure and body burden of environmental pollutants and risk of cancer in historically contaminated areas
}

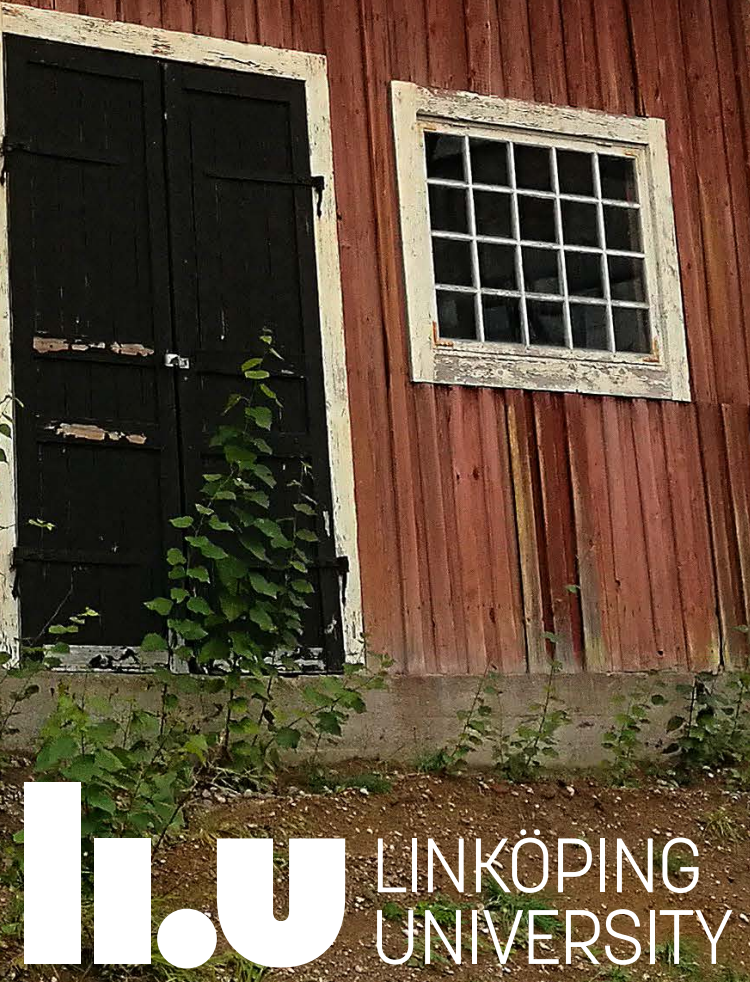




\section{Exposure and body burden of environmental pollutants and risk of cancer in historically contaminated areas}

Ingela Helmfrid

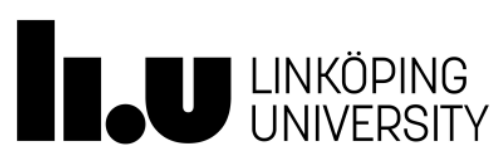

Occupational and Environmental Medicine Center, and Department of Clinical and Experimental Medicine Linköpings universitet, SE-581 83 Linköping, Sweden 
(C) Ingela Helmfrid, 2019

Printed in Sweden by LiU-Tryck, Linköping University, 2019

Linköping University medical dissertations, No. 1699

ISSN 0345-0082

ISBN 978-91-7685-006-0 
Exposure and body burden of environmental pollutants and risk of cancer in historically contaminated areas

\author{
By \\ Ingela Helmfrid \\ November 2019 \\ ISBN 978-91-7685-006-0 \\ Linköping University medical dissertations, No. 1699 \\ ISSN 0345-0082
}

Keywords: Contaminated area, cancer, exposure, metals, POPs, Consumption of local food

Occupational and Environmental Medicine Center, and

Department of Clinical and Experimental Medicine

Linköping University

SE-581 83 Linköping, Sweden 



\section{Preface}

This thesis is transdisciplinary, integrating toxicology, epidemiology and risk assessment, and involving academic institutions as well as national, regional and local authorities. Systematic and transparent methods for the characterization of human environmental exposure to site-specific pollutants in populations living in historically contaminated areas were used. Associations between environmental pollutant concentrations, exposure levels and observed or reported health effects were evaluated.

Due to the uncertainty regarding exposure and health risks in populations living in contaminated areas, the authorities and some of the people living in the contaminated areas in Gusum village and in the "Kingdom of Crystal" in Nybro and Emmaboda, in the county of Kalmar, contacted the Department of Occupational and Environmental Medicine at Linkoping University Hospital, Sweden. They wondered whether it is dangerous to live in these contaminated areas and whether they can consume home-grown vegetables, berries and fruit without health risks. Some of the residents in these contaminated areas regularly consume locally produced food, especially in the summer. Some of them were worried about cancer risks or their children's and grandchildren's health.

At the beginning, it was difficult to answer these questions and the attempt to do so initiated several discussions with experts at the Swedish Environmental Protection Agency, the Public Health Agency of Sweden, the Institute of Environmental Medicine at the Karolinska Institute, Stockholm, and with colleagues at Occupational and Environmental Medicine, Region Östergötland and at Linköping University. Additional uncertainties were identified, due to the many gaps in knowledge in this research area. In cooperation with local 
authorities and consultants, several exhaustive studies were performed, including environmental medicine assessments and research. Three of these studies are included in this thesis.

Hopefully, this thesis will increase our knowledge regarding the risks to human health posed by living in a contaminated area for shorter or longer periods of time, will be helpful in prioritizing substances/pollutants of high concern in contaminated sites and will support decision-making for remediation in historically contaminated areas. Hopefully, the results of this thesis will feed into the Swedish Environmental Protection Agency's (SEPA's) model for health-based generic guideline values (GVs) for contaminated soil. Finally, we hope that the results of the study will improve the residents' situation and reduce their anxiety, and ultimately improve public health.

\section{Ingela Helmfrid}




\section{List of scientific publications}

This thesis is based on the following papers, which are referred to in the text by their Roman numerals:

I Helmfrid I, Berglund M, Löfman O, Wingren G. Health effects and exposure to polychlorinated biphenyls (PCBs) and metals in a contaminated community. Environment International. 2012 Sep;44:538. Doi: 10.1016/j.envint.2012.01.009. Epub 2012 Feb 13.

II Helmfrid I, Salihovic S, van Bavel B, Wingren G., Berglund M. Exposure and body burden of polychlorinated biphenyls (PCB) and metals in a historically contaminated community. Environment International. 2015 Mar;76:41-8., Doi: 10.1016/j.envint 2014.12.004. Epub 2014 Dec 16.

III Helmfrid I, Ljunggren S, Nosratabadi R, Augustsson A, Filipsson M, Fredrikson M, Karlsson H, Berglund M. Exposure of metals and PAH through local foods and risk of cancer in a historically contaminated glassworks area. Environment International 131. Epub 2019, Juli 9. 



\section{Abstract}

There are many villages where environmental contamination is substantial due to historical industrial activities. According to the European Environment Agency, there are about 2.5 million potentially contaminated sites in the European member states. In Sweden, there are about 80000 more or less contaminated areas. About 1000 of them are classified into the highest risk category, Hazard Class 1, and should be remediated. Population exposure due to these industrially contaminated sites may contribute to adverse health effects and is a global environmental problem.

The general aim of this thesis was to evaluate the occurrence of cancer in populations residing in contaminated areas in relation to indirect exposure via the long-term consumption of locally produced food, taking into account residential, occupational and lifestyle factors. Associations between reported local food consumption frequencies, biomarker concentrations and environmental and lifestyle factors were explored. The Swedish national cancer registers and questionnaire information was used to identify cancer risk groups in the study population. The questionnaire was evaluated regarding how well it reflected measured levels of biomarkers in human biological samples, and how the consumption of local food from contaminated areas contributed to the total body burden of contaminants.

Despite historically high environmental levels of contaminants in the soil and sediments, current contaminant exposure in the studied population living in the contaminated areas was similar to or only moderately higher than that of the general population.

No significant associations with increased cancer risk were detected in the highest tertile of metals concentrations in blood or PAH in urine. 
Reported long-term high consumption of certain local foods was associated with higher cadmium (vegetarian food) and lead (fish, meat) concentrations in blood and urine. Long-term high consumption of nonlocal food from places outside the study areas was not associated with increased concentrations of metals compared with consumers of local food. It was concluded that the questionnaire information on consumption of locally produced food describes differences in food consumption in the study population reasonably well.

An increased risk of cancer was associated with smoking, family history of cancer and obesity. Residing in a contaminated area during the first five years of life was associated with an increased risk of cancer, which may indicate exposure to contaminants in early life. Also, long-term high consumption of particular local foods (fish, chicken, lamb, game meat) was associated with an increased risk of various forms of cancer, while reported high consumption of these foods from non-local sources was not associated with increased risk of cancer. The associations between habitual consumption of local food and different types of cancer may reflect a higher exposure in the past, and thus, if consumption of local food contributes to the risk of acquiring cancer, that contribution is probably lower today than previously. Furthermore, it cannot be ruled out that other contaminants in the food contribute to the increased cancer risks observed.

In conclusion, the questionnaire that was developed for the present thesis can identify risk groups within populations and can be used as a tool in a health-risk assessment. 


\section{Sammanfattning}

\section{Är det farligt att bo i förorenade områden?}

Industrialismen har inte bara medfört positiv utveckling, utan också bidragit till utsläpp av föroreningar till luft, mark och vatten på många platser i världen. Idag är utsläppen från industrin betydligt mindre på grund av miljökrav från myndigheter, vilka inte fanns tidigare. I Europa finns det omkring 2,5 miljoner områden som har förorenats av historiska utsläpp. I Sverige finns cirka 80000 förorenade områden, varav 1000 områden är allvarligt förorenade och behöver genomgå sanering. I närheten av dessa områden bor många människor som riskerar att utsättas för höga halter av föroreningar, som eventuellt kan bidra till allvarliga hälsoeffekter. Fisk, grönsaker, svamp, bär etc. kan innehålla förhöjda halter av skadliga ämnen, som kan leda till ökad kroppsbelastning av föroreningar.

Syftet med avhandlingen var att studera om boende i förorenade områden har varit mer utsatta för skadliga ämnen, och om de i så fall har en högre kroppsbelastning av dessa ämnen och även utvecklat cancer. Samband mellan långvarig konsumtion av lokalt producerad mat och halter av föroreningar i blod/urin, och cancerrisk har studerats. Även andra riskfaktorer (t.ex. rökning, ärftlighet, ålder) för cancerutveckling har identifierats. Ett annat syfte var att ta fram ett verktyg i form av en enkät som kan användas för riskbedömning av befolkningar i förorenade områden.

Två områden, Gusum i Östergötland och Glasriket i Småland har studerats. Boende har identifierats med hjälp av geografiskt informationssystem (GIS) och befolkningsregister. Information om cancer har hämtats från Cancerregistret. Enkät med frågor om boendeort, livsstil, rökvanor, matvanor, yrke, sjukdom, medicinering har skickats till slumpvis utvalda personer i dessa studieområden. Ett urval av de som svarat på enkäten fick också lämna blod och urinprov. 
Trots att höga nivåer av metaller uppmätts i marken (Gusum, Glasriket) tidigare och långlivade organiska miljögifter i fisk (Gusum), uppvisar inte befolkningen högre exponering för föroreningarna idag. Nivåerna av dessa ämnen i blod och urin hos studiedeltagarna som grupp var i samma nivå, eller bara något högre, jämfört med andra befolkningsgrupper i Sverige.

Vid närmare kontroll av studiedeltagarnas kost, upptäcktes ett samband mellan hög konsumtion av lokalt odlade rotfrukter och grönsaker och högre nivåer av kadmium i kroppen i båda studiepopulationerna. Det fanns också ett samband mellan hög konsumtion av lokal fisk, lamm, kyckling samt viltkött och högre halt av bly i blodet hos befolkningen i Glasriket. Enkäten fångar delvis exponeringen för metaller via livsmedel, dvs. att de högsta exponeringarna återfinns i högkonsumentgrupperna. Det visar att enkäten kan användas för riskbedömning av befolkningar i förorenade områden.

I båda studierna fanns ett samband mellan konsumtion av lokalt fångad fisk och förhöjd cancerrisk. I glasrikestudien fanns också ett samband mellan förhöjd risk för vissa typer av cancer och långvarig hög konsumtion av lokalproducerat kött och lokalfångad fisk. Att ha bott i glasriket under sina fem första levnadsår var också kopplat till högre cancerrisk. Men att det finns ett statistiskt samband, måste inte innebära att konsumtionen av dessa livsmedel bidragit till en förhöjd risk att utveckla cancer.

De identifierade cancerriskerna som visar samband med hög konsumtion av lokal föda, speglar sannolikt en historiskt högre exponering för metaller och andra föroreningar. Om konsumtion av lokala livsmedel har bidragit till utveckling av vissa cancerformer, så är risken för att utveckla cancer med dagens exponering sannolikt mycket lägre. 


\section{Table of contents}

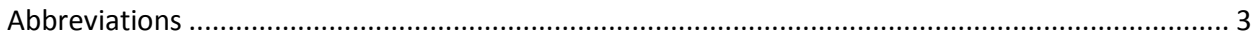

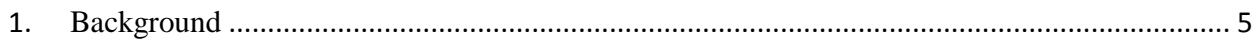

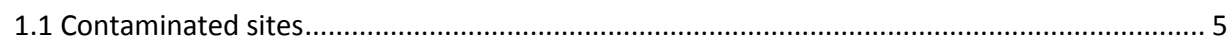

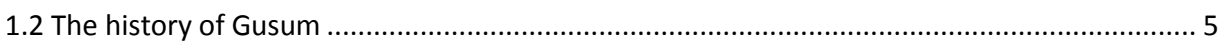

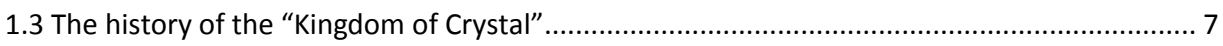

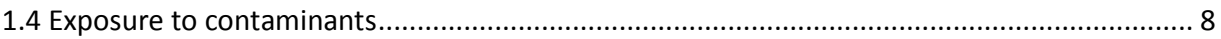

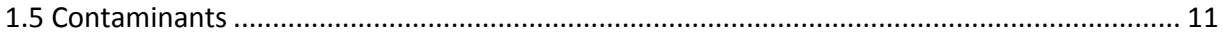

1.6 Health-risk assessments at contaminated sites ................................................................... 17

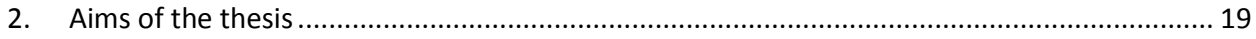

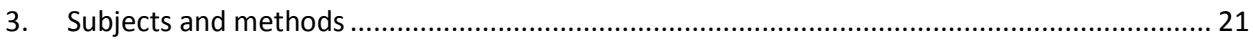

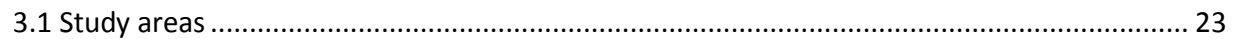

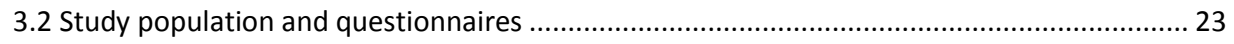

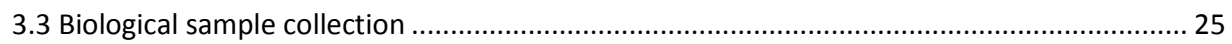

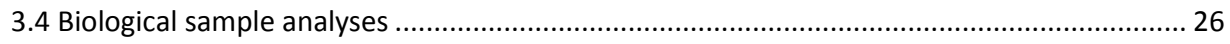

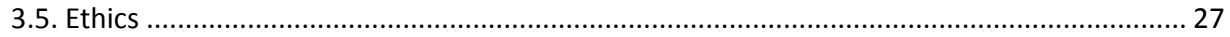

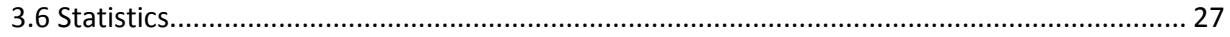

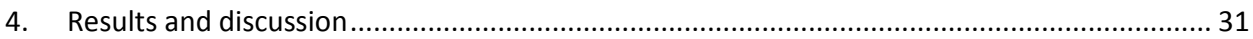

4.1 Health risks associated with living in a contaminated area (Papers I and III) .......................... 31

4.2 Association between consumption of local food and risk of cancer (Papers I and III) ............ 32

4.3 Identified factors of relevance to exposure and dose interpretations (Papers I-III) ............... 34

4.4 Association between measured levels of toxic substances in blood/urine and consumption of

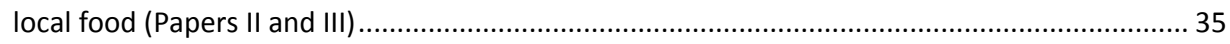

4.5 How well does the questionnaire data reflect measured levels in human biological samples?

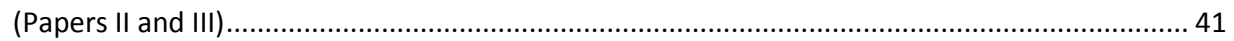

4.6 Identified health effects in populations living in contaminated areas (Papers I-III) ............... 41

4.7 Are populations residing in contaminated areas more exposed than others? (Papers II and III)

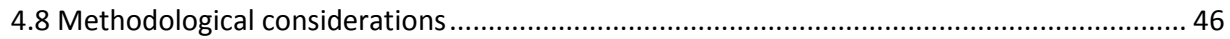

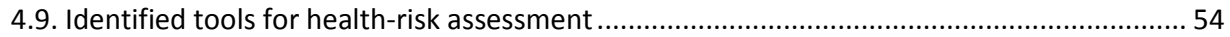

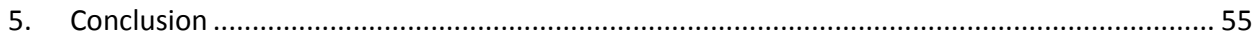

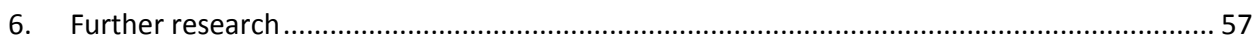

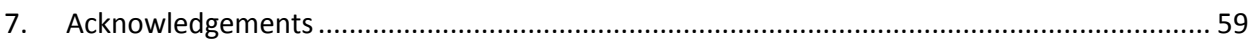

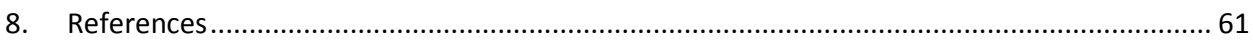




\section{Abbreviations}

Ag

ANOVA

As

ATSDR

$\mathrm{Ba}$

B

B-As

B-Cd

$\mathrm{B}-\mathrm{Pb}$

BMDL

BMI

$\mathrm{Cd}$

CI

Co

$\mathrm{Cu}$

$\mathrm{Cr}$

DDE

DMA

DL-PCB

EC

$\mathrm{Fe}$

FFQ

EFSA

GV

$\mathrm{Hg}$

IARC

IQ
Silver

Analysis of variance

Arsenic

Agency for Toxic Substances and Disease Register

Barium

Boron

Arsenic in blood

Cadmium in blood

Lead in blood

Limit of the Benchmark Dose

Body Mass Index

Cadmium

Confidence intervals

Cobalt

Copper

Chromium

Dichlorodiphenyldichlorethylene

Dimethylarsenic

Dioxin-like Polychlorinated biphenyls

European Commission

Iron

Food frequency questionnaire

European Food Safety Authority

Guideline values

Mercury

International Agency for Research on Cancer

Intelligence Quotient 


\begin{tabular}{|c|c|}
\hline M-H OR & Mantel-Haenzel Odds Ratio \\
\hline $\mathrm{Mg}$ & Magnesium \\
\hline MMA & Methylarsonic acid \\
\hline $\mathrm{Mn}$ & Manganese \\
\hline MT & Metallothionein \\
\hline NDL-PCB & Non-dioxin like Polychlorinated biphenyls \\
\hline $\mathrm{Ni}$ & Nickel \\
\hline NIPALS/PCA & Nonlinear Iterative Partial Least Squares/Principal Component Analysis \\
\hline 1-OHPy & 1-hydroxipyren \\
\hline OR & Odds ratios \\
\hline $\mathrm{Pb}$ & Lead \\
\hline PAH & Polycyclic aromatic hydrocarbon \\
\hline PCA & Principal Component Analysis \\
\hline PCB & Polychlorinated biphenyls \\
\hline POP & Persistent organic pollutants \\
\hline ppm & Parts per million \\
\hline $\mathrm{Sb}$ & Antimony \\
\hline SD & Standard deviation \\
\hline SEPA & Swedish Environmental Protection Agency \\
\hline TEF & Toxic equivalence factor \\
\hline TEQ & Toxic equivalency quotient \\
\hline US EPA & United States Environmental Protection Agency \\
\hline U-As & Arsenic in urine \\
\hline U-Cd & Cadmium in urine \\
\hline $\mathrm{U}-\mathrm{Pb}$ & Lead in urine \\
\hline $\mathrm{Zn}$ & Zinc \\
\hline WHO & World Health Organization \\
\hline
\end{tabular}




\section{Background}

\subsection{Contaminated sites}

Population exposure to toxins due to industrially contaminated sites may contribute to adverse health effects and is a global environmental problem. According to the European Environment Agency, there are about 2.5 million potentially contaminated sites within the EU member states (Panagos et al. 2013), so there are obviously a large number of people at potential risk. An inventory of contaminated sites in Sweden, created in cooperation between the Swedish Environmental Protection Agency and local authorities, showed the existence of about 80000 more or less contaminated areas (SEPA 2012). About 1000 of them were classified into the highest risk category, Hazard Class 1, and should be remediated (SEPA 2018). The toxic substances in contaminated soil and water derive from past industrial activities, such as the chemical industry, mining and metals industry, wood impregnation, the pulp and paper industry and glass mills. Typically, elevated levels of metals (mercury, arsenic, cadmium and lead), polychlorinated biphenyls (PCBs) and dioxins are found in many contaminated areas. Exposure to these contaminants has been associated with a variety of adverse health effects in humans, including carcinogenic, neurotoxic and endocrine-disrupting effects as well as negative effects on the kidneys and the skeleton (Steenland et al. 2000; Arisawa et al 2001; Calderon et al. 2003; Hellström et al. 2007; Julin et al. 2012; Åkesson et al. 2014; Thomas et al. 2014). The human body burden of metals and POPs (persistent organic pollutants) is mainly due to dietary intake (Darnerud et al, 2006; Järup \& Åkesson 2009; Törnkvist et al. 2011; Bjermo et al. 2013).

\subsection{The history of Gusum}

One of the first inventories of contaminated areas in Sweden began during 2002-2003 in the village of Gusum, located in the County of Östergötland. In this area, the industrial production of brass items and other metal components, including zippers, has been going on since the $1650 \mathrm{~s}$, and emissions of metals to the air and soil, as well as emissions of oil to the water, have been substantial (Figures 1 and 2). Flue gas purification was introduced in 1983 (County Administrative Board Östergötland 2003). Environmental measurements in the area, carried out by local authorities during the 1970s, ' 80 s and '90s, had revealed high levels of zinc (Zn), copper $(\mathrm{Cu})$, lead $(\mathrm{Pb})$ and cadmium $(\mathrm{Cd})$ in the soil, vegetables, root crops, berries and mushrooms. In addition, in 1972, a large quantity of oil contaminated with polychlorinated biphenyls (PCBs) was accidentally spilled into the river that was running through the village. Some years later, sediment from the river was removed and deposited on the ground at a location close to the site of the original spill. The authorities also suspected that PCBs from the landfill had leaked back into the river again. 


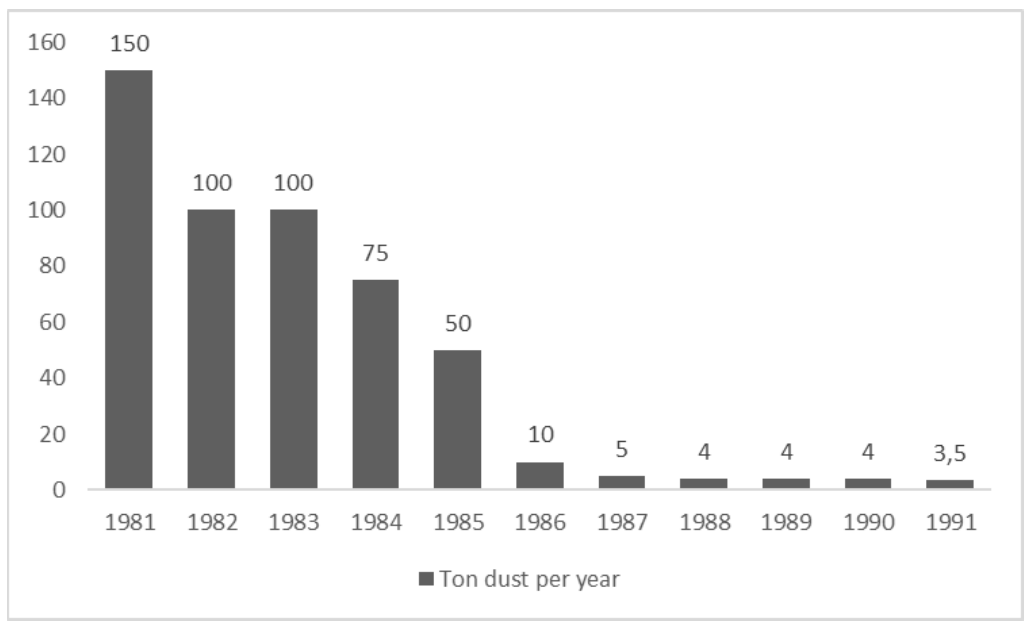

Figure 1. Total emissions of dust to the air (1981-1991) reported by Boliden Gusum (Valdemarsvik municipality 1992).

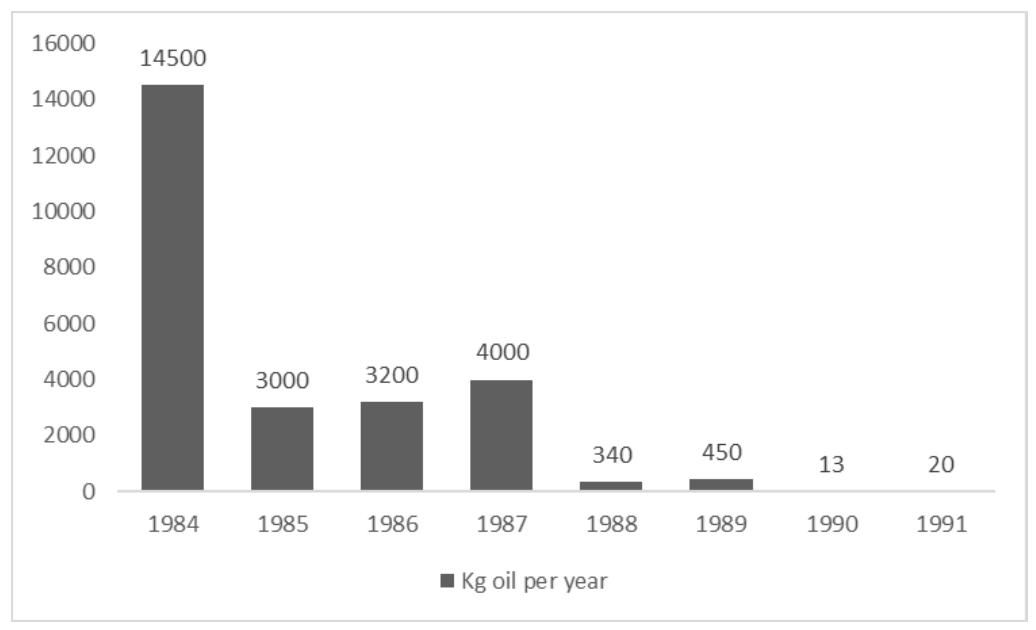

Figure 2. Total emissions of oil to the river (1984-1991) reported by Boliden Gusum (Valdemarsvik municipality 1992).

In 1981, the National Food Administration issued local dietary recommendations stating that consumption of locally grown vegetables, berries and fish from within a radius of $3 \mathrm{~km}$ around the brass works industry should be avoided, due to high levels of PCBs in the river (100-500 times higher than generally detected in lean fish) and high levels of metals in locally grown vegetables, with values 2-50 times higher than background values in foods on the general Swedish market (Helmfrid et al. 2007; Sundström 1993). Compliance with the dietary recommendations issued by local authorities is not known. 
Measurements of PCBs in 2006 and 2010 showed persistently high PCB concentrations in local pike and perch, although the levels were below the WHO's/EC's maximum levels for fish, which were $8 \mathrm{pg}$ TEQ/g fresh weight for dioxins and dioxin-like PCBs (EC 2006; Helmfrid et al. 2007; Nyberg et al. 2012). Both low- and highly chlorinated PCB congeners were found in local fish, with a dominance of the low-chlorinated congeners. Also, the levels of metals in soil, berries and chanterelles exceeded background levels by 1-20 times in both 2006 and 2010, and in some locations exceeded EU maximum levels for Cd in lettuce, chanterelles and cep, and for $\mathrm{Pb}$ in lingonberries, chanterelles and cep (EC 2006; Helmfrid et al. 2007; Nyberg et al. 2012).

\subsection{The history of the "Kingdom of Crystal"}

The geographical area of Kalmar and Kronoberg Counties, in the south-eastern part of Sweden, County of Småland, is often referred to as the "Kingdom of Crystal", and is located in the municipalities of Emmaboda, Nybro, Uppvidinge and Lessebo. In this area, about 25 glassworks used to be located. Today, only 13 glassworks and small glass studios are still active in the "Kingdom of Crystal". The production of glass has been ongoing since the 1740s on a small scale at a few glass works, but in the middle of the $19^{\text {th }}$ century, glass production units were increased in Sweden. They became concentrated in this area due to the long tradition of lead crystal and colourful art glass productions created by skilled glassblowers, and due to the proximity to streams and the access to firewood from the deep forests of Småland (The Swedish Federation of Glazing Contractors 2017).

Several metal oxides were added to the glass batches during production. The main component was silica sand. Soda or potash was added as a fluxing agent to reduce the fusion point of the silica sand. Calcium oxide was added to increase the stability of the glass. Saltpetre or arsenic trioxide, and more recently antimony ( $\mathrm{Sb}$ ), were added to remove gas bubbles during the smelting process. Arsenic acid was used as a decolourizer. Lead oxides gave the characteristic optical properties of crystal glass. Metal oxides of $\mathrm{Cd}$, chromium $(\mathrm{Cr})$, cobalt $(\mathrm{Co}), \mathrm{Cu}$, iron $(\mathrm{Fe})$, manganese $(\mathrm{Mn})$ and nickel $(\mathrm{Ni})$ have all been used as colour pigments to a greater or lesser extent (SEPA 1978; Löf \& Thor 1986).

The International Agency for Research on Cancer found evidence that occupational exposure in glass manufacturing increases the risk of cancer (IARC 1987). Emerging understanding of hazards related to the work environment has forced the introduction of preventive actions such as the substitution of As with $\mathrm{Sb}$ and substitution of lead $(\mathrm{Pb})$ in crystal glass (Löf \& Thor 1986). Epidemiological studies in the "Kingdom of Crystal" have shown that art glass workers have an increased risk of dying from cancer of the stomach, colon and lung and from cardiovascular diseases (Wingren 1991). Glass blowers showed the highest risks of cancer, probably due to exposure through the inhalation of airborne substances and ingestion of particles entering the mouth via the blowpipe.

In addition to concerns about the work environment, glass production has also caused contamination of the surrounding environment by significantly increasing waste products and the atmospheric deposition of metals. Wastewater from the grinding process was probably 
released directly to the recipient watercourse (Elert \& Höglund 2012). Highly contaminated areas have been identified around 22 glassworks in the "Kingdom of Crystal". Soil and groundwater in these spots are heavily polluted by arsenic $(\mathrm{As})$, lead $(\mathrm{Pb})$, cadmium $(\mathrm{Cd})$, nickel (Ni), cobalt (Co), boron (B), barium (Ba), antimony ( $\mathrm{Sb}$ ) and zinc ( $\mathrm{Zn}$ ) (Höglund et al. 2007). Mosses and water plants have increased concentrations of $\mathrm{Pb}$ and $\mathrm{As}$ in particular (SEPA 1978; Göransson 1983), but also Cd, Zn and Cu (Ohlsson 1990). In addition, sediment and crayfish from the vicinity of glassworks contain elevated levels of $\mathrm{Pb}$ and to some degree also As and Cu (SEPA 1978). Even so, in a study from the Swedish glassworks region, no significant differences could be found between $\mathrm{Pb}$ or As concentrations in children living in the vicinity of a glassworks and children living in a reference area (Andrén et al. 1988). In a study from Kalmar County, an increased risk of brain cancer mortality was found among people living in parishes with glassworks as compared to the Swedish population in general (Wingren \& Axelson 1992). In a recent register study within the same area, significantly elevated cancer incidences were observed for total cancers, cancers of the digestive system, and for cancer of the prostate, lymphatic and hematopoietic system (Nyqvist et al 2017). In the same study, a dose-response relationship between $\mathrm{Cd}$ and $\mathrm{Pb}$ contamination levels in soil and total cancers and cancer of the digestive system, as well as for prostate cancer, was observed.

\subsection{Exposure to contaminants}

In general, humans are exposed to various contaminants during their lifetime via general food intake, textiles, dust, air, chemical use, occupation, lifestyles, housing environments, etc. Living in a contaminated area may contribute to this exposure to contaminants. The exposure pathways and exposure time are of importance for the prediction of human health risks in a contaminated area. Hazards do not occur in the absence of exposure. The primary objectives of exposure assessments are to determine significant sources of contaminants and the extent and duration of contact with them for a population. In general, individuals may be exposed to contaminants via ingestion, inhalation and dermal contact (European Commission 2013). Exposure may occur via direct and/or indirect contact with contaminated soil. The direct exposure pathways include ingestion of soil, dermal contact with soil, and inhalation of soil particles, dust and exhaust fumes and gases. Soil contaminants can move from soils into surface water or groundwater, leading to contaminated drinking water or irrigation water. The contaminants (mainly metals) can be taken up by plants via irrigation water or directly from the soil. These exposure pathways are indirect and include ingestion of locally produced food, including root crops, vegetables, fruit, berries, mushrooms, fish, game, meat, other agricultural and dairy products and drinking water (Figure 3). 


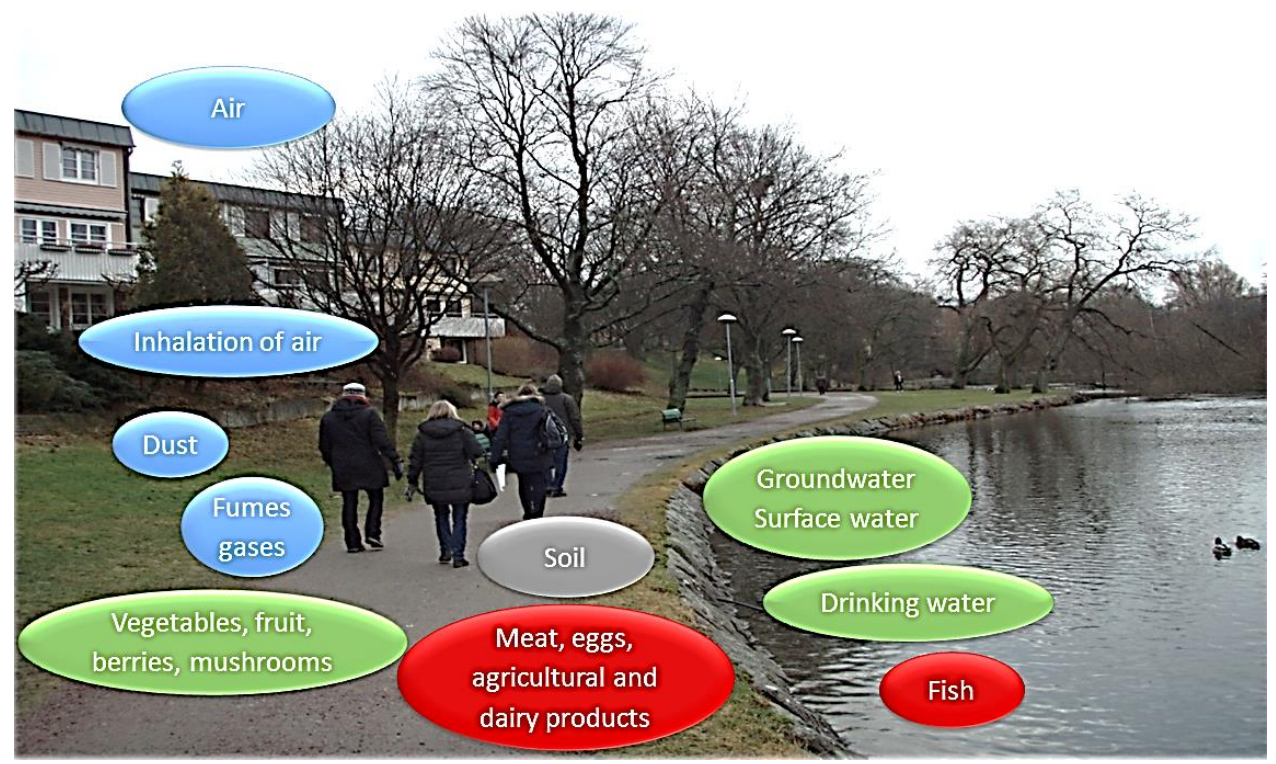

Figure 3. Direct (blue, grey ovals) and indirect (green, red ovals) exposure routes of contaminants from soil. Fish, meat, eggs, dairy products etc. (red ovals) are not included in the calculation of the guidance values from the Swedish EPA (SEPA 2009).

Soil and dust ingestion are common pathways of contaminant exposure in children, because soil and dust can unintentionally be transferred from the hands to the mouth and eyes. Children tend to place toys and fingers in their mouths, and they spend a lot of time playing on the ground and on the floor indoors. Contaminated outdoor soil and dust can also be transferred via clothing and shoes to indoor environments and thereby become a source of indoor dust. Children with a decidedly hand-to-mouth behaviour (soil-pica behaviour) may ingest about 1000-5000 mg soil/day or more (US EPA 2002). Via this exposure route, they can ingest high levels of contaminants and run the risk of acute health effects. Likewise, adults can ingest small amounts of contaminated soil and dust via the consumption of unwashed vegetables, berries and fruit.

Historical emissions from industry, before flue-gas purification was introduced in the 1980s, meant that inhalation and ingestion of dust, vapour and aerosols were common exposure pathways. According to the estimated emission of $\mathrm{Pb}$ into the air in Sweden, the major part derives from Swedish crystal-glass production (Larsson et al. 1999). The highest levels of airborne $\mathrm{Pb}$ and $\mathrm{As}$ have been measured in mosses within 200 metres of a glassworks in Sweden (Göransson 1983). Then, levels decreased with distance, but at 2000 metres from the source the levels were still elevated compared with backgrounds levels. The levels were higher on the eastern side of the chimney, due to a predominantly westerly wind direction (Figure 4). This indicates that metals may also be deposited in gardens close to a glassworks or other metal production industries. These metals may be deposited on vegetables, fruit and berries as well as the residents, resulting in chronic exposure to low-level metal concentrations over a lifetime. Metal uptake in vegetables in areas with industrial emissions 
have been documented in several studies (Hellström et al. 2007; Helmfrid et al. 2007; Sundstrom \& Jorhem 2008; Nyberg et al. 2012; Uddh-Söderberg et al. 2015; Augustsson et al. 2015; Dziubanek et al. 2015; Yousaf et al. 2016; Ur Rehman et al. 2017; Augustsson et al. 2018).
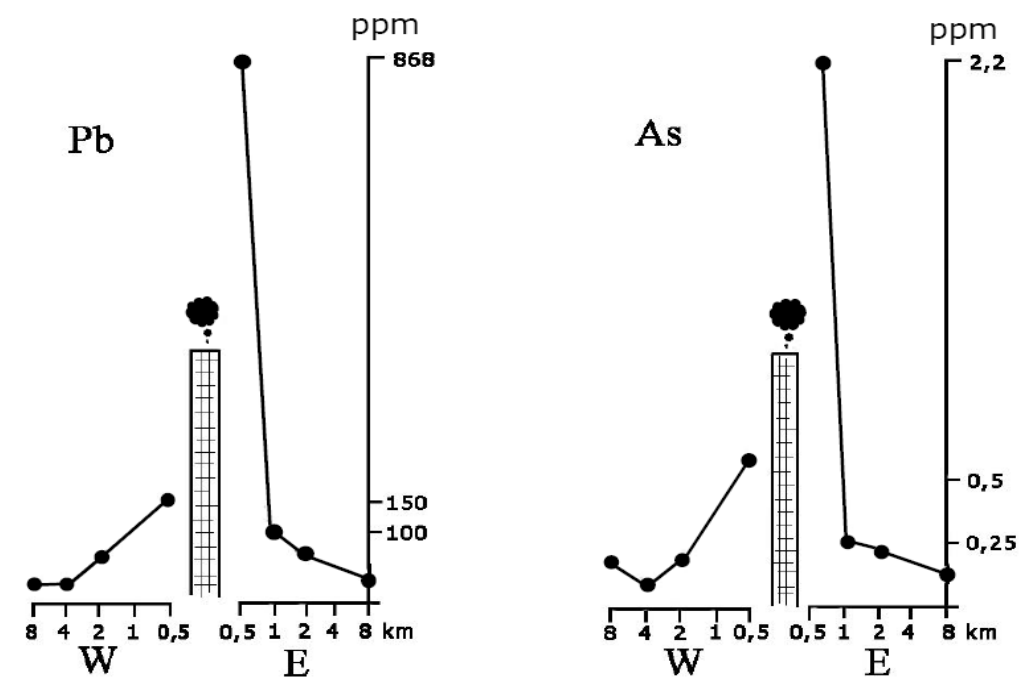

Figure 4. Gradients of $\mathrm{Pb}$ and As in regions with predominantly westerly wind direction (W) and easterly wind direction (E) at Kosta glassworks. Mean concentrations in $\mu \mathrm{g} / \mathrm{g} T \mathrm{~S}$ in the moss Pleurozium shreberi in 37 samples sites at different distances from Kosta glassworks. The figure is modified from Göransson (1983).

\subsubsection{Direct and indirect exposure assessment approaches}

Biomonitoring is a method that is used to assess both direct and indirect (total) exposure to toxic environmental substances and their metabolites in human tissues or specimens, such as breastmilk, hair, blood and urine. Biomonitoring data summarizes exposure from all routes and pathways but does not identify specific sources of multiple exposure routes (NRC 2006). Biomonitoring is a crucial tool in studies of human health. Blood and urine are the most commonly used and accepted matrices for the evaluation of exposure levels and body burden of specific substances in the human body.

One way to identify the exposure routes is to use a food frequency questionnaire (FFQ), which can be used to estimate the indirect exposure to contaminants via average food consumption over a specific time period. To complement an FFQ, information about covariates such as education, residence, occupation, medical history, smoking habits etc. can also be collected through a general questionnaire. Information from the FFQ can also be used to monitor statuses and trends in exposure over time. Unfortunately, FFQs asking about consumption in the past are difficult to respond to, mainly because respondents cannot 
remember the exact consumption frequency from several years ago, but it provides a hint about approximate consumption over time. The responses from an FFQ contain several types of error. These errors can be mitigated through statistical modelling, and FFQ is the most widely used practical method for capturing food consumption in retrospective case-control studies.

This thesis will evaluate whether FFQs can identify risk categories for populations and how they could be used as a tool in risk assessments. It will also evaluate how well the questionnaire data reflects measured levels of biomarkers in human biological samples, and whether these results correspond with measured levels of contaminants in local food.

\subsection{Contaminants}

\subsubsection{Arsenic}

Arsenic (As) has been used as a treatment for malaria, syphilis, asthma, chorea, eczema, psoriasis and cancer (Hughes et al. 2011). Until the mid-1850s, As was a familiar poison and has been used as a homicidal and suicidal agent, because it is odourless and tasteless and thus undetectable in food and beverages. It has also been used in pigments and as a pesticide (Hughes et al. 2011; Bolt 2012). In the environment, As occurs naturally in both inorganic and organic forms. The inorganic form is more toxic than the organic arsenic species. In the bedrock, As generally occurs in sulphide form in mineral complexes together with $\mathrm{Pb}, \mathrm{Cu}, \mathrm{Ni}$, $\mathrm{Sb}, \mathrm{Co}, \mathrm{Fe}$ and silver (Ag) (WHO 2001; IARC 2012). High concentrations of As occur in areas with volcanic bedrock or geological deposits of sulphide minerals (WHO 2001; Muñus et al. 2002). Anthropogenic sources of inorganic As releases to the environment include both industrial production and emissions such as mining, smelters, glass manufacturers, the pharmaceutical industry, antifungal wood and leather preservatives, pigments, antifouling paints, poison baits and agrochemical production (EFSA 2009; EC 2013). In the environment, As is mainly transported by water. The forms and concentrations of As depend on several factors, including $\mathrm{pH}$, the redox potential and degree of biological activity. The inorganic forms, also called arsenite or arsenate, predominate under reducing conditions in deep wellwaters and groundwater. In oxygenated water, arsenic usually occurs as arsenate. Methylation of inorganic As is associated with biological activity. Some organisms, mainly in marine water, and to a lesser extent in fresh water and soil, can transform inorganic As into organic compounds, such as arsenobetaine, arsenocholine and arsoniumphospholipids (WHO 2001; EC 2013). Inorganic As compounds tend to adsorb to soils, and leakage usually results in transportation over only short distances. In natural soils with low As concentrations, the availability for plant uptake is generally low, mainly because of the strong adsorption to clay, organic matter, Fe, Mg and aluminium oxyhydroxides (EC 2013). In areas with elevated levels of As, terrestrial plants may accumulate it by root uptake from the soil. Certain species, especially rice and algae, may accumulate substantial levels of As (EFSA 2009). In studies of contaminated areas, levels of total As were found in cereal products, onions, lettuce, potatoes, carrots and beetroot (Muñus 2002; EFSA 2009; Uddh-Söderberg 2015). In the glassworks area in Sweden, levels of total As in lettuce and potatoes were increased at soil concentrations 
above $10 \mathrm{mg} / \mathrm{kg}$, which is the generic soil guideline for residential areas (Uddh-Söderberg 2015).

Inhalation of As-containing particulates is the primary route for occupational exposure, but ingestion and dermal exposure can also occur (IARC 2012a; IARC 2012b). The general population is exposed to As through drinking contaminated water, using contaminated water in food preparation, irrigation of food crops, industrial processes, eating contaminated food and smoking (IARC 2012a; IARC 2012b; EC 2013). Inorganic As is the predominant form found in water, rice, cereals, dairy products, meat and poultry. In seafood, fruit and vegetables, As is mainly found in its less toxic organic forms (IARC 2012a). The International Agency for Research on Cancer (IARC) has classified arsenic and inorganic arsenic compounds as a human carcinogen, group 1 (IARC 2012a; IARC 2012b). Long-term exposure to inorganic As may lead to chronic arsenic poisoning such as skin lesions (hyperkeratosis and hyperpigmentation), peripheral neuropathy, black foot disease (a severe form of peripheral vascular disease) cardiovascular disease, and cancer of the skin, lung, bladder and liver (ATSDR 2007; IARC 2012a; IARC 2012b). After either repeated exposure at lower levels or single higher doses of inorganic arsenic, nausea, vomiting and diarrhoea are commons symptoms. Acute exposures to high levels of As may cause encephalopathy, with confusion, hallucinations, impaired memory and emotional lability (ATSDR 2007).

Soluble inorganic As present in drinking water is rapidly and almost completely (about $95 \%$ ) absorbed after ingestion (ATSR 2007). The absorption of ingested inorganic As from food varies (about 30-85\%), depending on the solubility, the presence of other food nutrients/constituents in the gastrointestinal tract and the kind of As compound in the food. Absorption of organic arsenic is generally greater than $70 \%$. After absorption, As is distributed to the liver, kidneys, heart, lungs, brain and placenta. Inorganic As is methylated to methylarsonic acid (MMA) and dimethylarsenic (DMA) by alternating reduction of pentavalent As to trivalent As. The methylated As is rapidly excreted in the urine within a few days (Vahter 2002; ATSDR 2007; EFSA 2009). Arsenic accumulates in keratin-rich tissues and total As concentrations in the hair and nails are used as indicators of past exposure, while blood and urine are used as indicators of recent exposure (IARC 2012a; IARC 2012b; Orloff et al. 2017). Concentrations of As in the blood are lower than those in urine and it may be analytically difficult to detect low-level exposures. Instead, urine is the most frequently used biological medium for biomonitoring of As, and it is useful to distinguish between As species, since the species differ in toxicity (Orloff et al. 2017).

\subsubsection{Cadmium}

Cadmium $(\mathrm{Cd})$ is present in the earth's crust in association with $\mathrm{Zn}, \mathrm{Pb}$ and $\mathrm{Cu}$. It is a toxic by-product of $\mathrm{Zn}, \mathrm{Pb}$ and $\mathrm{Cu}$ mining and smelting, but also a pollutant deriving from other industrial and agricultural sources. Cadmium has been used for manufacturing nickelcadmium batteries, for electroplating, making polyvinyl chloride plastics as well as paint pigments in glass, artists' colours, glazes, ceramics, rubber and in plastics (WHO 2010; IARC 2012c). Among non-smokers, the major source of exposure is food since $\mathrm{Cd}$ is easily taken up 
by plants from soil, water and fertilizers. Molluscs and crustaceans contain $\mathrm{Cd}$, because they accumulate it from the water (WHO 2010; IARC 2012c). The uptake of Cd among different plants depends on its bioavailable concentrations in the soil, the species of plants and geochemical properties as well as the hydrological conditions of the soil (Augustsson et al. 2015; Yousaf et al. 2016). The uptake process of soil Cd by plants is largely controlled by the $\mathrm{pH}$. The Cd mobility and bioavailability are higher at low $\mathrm{pH}$ in soil, and lower at high $\mathrm{pH}$ (EC 2013). For smokers, active inhalation of tobacco smoke is also a major route for Cd exposure, because the tobacco plant naturally accumulates $\mathrm{Cd}$ in its leaves (Järup \& Åkesson 2009; WHO 2010).

Approximately 3-5\% of ingested $\mathrm{Cd}$ is absorbed in the intestine, but the absorption is higher in the presence of iron deficiency, due to the fact that cadmium ions compete with iron ions for a common binding site in the iron-transfer system in the intestine (Berglund et al. 1994). $\mathrm{Cd}$ binds to albumin and is transported to the liver where it interacts with metallothionein (MT). Cd-MT is transferred through the glomerular membranes into the tubular fluid in the kidney and then accumulates. The biological half-life for $\mathrm{Cd}$ ranges from 10-30 years and $\mathrm{Cd}$ accumulates in the body with age (EFSA 2009; Järup \& Åkesson 2009; Nordberg \& Nordberg 2016). Long-term exposure may cause renal tubular dysfunction and softening of the bones followed by osteoporosis. Low-level environmental exposure to $\mathrm{Cd}$ may mobilize bone minerals from the skeletal tissue, either indirectly due to renal dysfunction or via direct bone damage (EFSA 2009; Åkesson 2014; Nordberg \& Nordberg 2016). Effects on bone mineral density, osteoporosis and increased risk of fractures are reported to occur at cadmium in urine (U-Cd) 0.5-2 $\mu \mathrm{g} / \mathrm{g}$ creatinine (Åkesson et al. 2014).

Cadmium in tobacco smoke is effectively absorbed in the lungs (Järup \& Åkesson 2009). Inhalation of $\mathrm{Cd}$ is associated with lung dysfunction, such as chronic obstructive airways disease and lung cancer. The IARC has classified $\mathrm{Cd}$ as a human carcinogen, group 1, mainly based on lung cancer cases among workers (IARC 2012c). Other cancer sites, such as prostate, pancreas, kidney and bladder, have been reported in occupational epidemiological studies, but the results were inconsistent and mainly based on small numbers of cases (IARC 2012c). Recent studies of $\mathrm{Cd}$ exposure and cancer in the general population indicate associations, with an increased risk of cancer in the lungs, bladder, breast, prostate and endometrial cancer (Åkesson et al. 2014), and increased risk of cardiovascular disease and mortality (Barregård et al. 2016; Larsson \& Wolk 2016), but additional studies are needed to confirm these associations.

Cadmium in urine (U-Cd) and cadmium in blood (B-Cd) are the commonly used biomarkers to assess exposure or body burden of $\mathrm{Cd}$. U-Cd reflects the kidney and body burden, while BCd reflects both long-term cumulative exposure and body burden and recent exposure (Åkesson et al. 2014; Åkerström et al. 2014; Nordberg \& Nordberg 2016).

\subsubsection{Lead}

Lead $(\mathrm{Pb})$ is a naturally occurring toxic metal but is primarily an environmental pollutant. It has been used in anthropogenic activities such as mining, smelting, manufacturing, recycling 
activities, in pigments and paints, gasoline, fuel, solder, stained glass, lead crystal glass, ammunition, ceramic glazes, jewellery, toys, cosmetics, water pipes, dietary supplements and for medical purposes (IARC 2006; EFSA 2012a; WHO 2016). Human adult exposures stem mainly from food (cereal products, root crops, leafy vegetables, dairy products, meat, seafood, wine) and water, but some exposure occurs via smoking, air, dust and soil. Soil and dust may be significant sources of $\mathrm{Pb}$ exposure in young children due to their hand-to-mouth behaviour (EFSA 2012a). In several contaminated areas, industrial emissions of $\mathrm{Pb}$ have been important exposure sources. Almost all $\mathrm{Pb}$ in the air is bound to particles of $0.5-10 \mu \mathrm{m}$ and may be transported over hundreds of kilometres. $\mathrm{Pb}$ particles are dispersed and removed from the atmosphere by wet or dry deposition. In many countries, $\mathrm{Pb}$ has been phased out from gasoline and is still being phased out of various products (EFSA 2012a; WHO 2016). However, it is still being used in ammunition. High levels of $\mathrm{Pb}$ have been found around the wound channel of shot, and consumers of game meat have shown higher levels of $\mathrm{Pb}$ in the blood than the general population (Iqbal et al. 2009; Meltzer et al. 2013; Bjerselius et al. 2014; Kollander et al. 2014). The Swedish National Food Agency has introduced dietary advice on the consumption of game meat based on these results. They advise against consumption of affected meat around the wound channel (Bjerselius et al. 2014).

$\mathrm{Pb}$ concentrations in soil generally decrease as the distance from the contaminating source increases. The uptake of $\mathrm{Pb}$ from the soil by vegetable root systems is generally low. The amount of uptake depends on the cation exchange capacity, $\mathrm{pH}$, and amount of organic matter, soil moisture content and type of plants. The bioavailability increases at low $\mathrm{pH}$, at low organic content of the soil and in highly $\mathrm{Pb}$-contaminated areas. Airborne $\mathrm{Pb}$ is mainly accumulated at the surface of leafy vegetables and can be removed if the vegetables are washed (WHO 2007; ATSDR 2007).

The uptake of ingested or inhaled $\mathrm{Pb}$ depends on the type of compounds (inorganic, organic), particle size, site of contact with the body, acidity of the body fluid, and the physiological status of the individual (IARC 2006). Inorganic lead absorption from the gastrointestinal tract is influenced by age. Children absorb a larger fraction than adults. Absorbed $\mathrm{Pb}$ is distributed from blood plasma into erythrocytes and accumulates in soft tissues and the skeleton. From the skeleton, $\mathrm{Pb}$ is released gradually back into the bloodstream, particularly during pregnancy, lactation and osteoporosis. Maternal transfer of $\mathrm{Pb}$ may occur through the placenta and during breastfeeding. Half-lives of $\mathrm{Pb}$ are approximately 30 days in blood and 10-30 years in bone, and excretion occurs primarily via urine and faeces (IARC 2006; EFSA 2012a).

Children are particularly vulnerable to the neurotoxic effects of $\mathrm{Pb}$, and even relatively low levels of exposure to $\mathrm{Pb}$ may cause neurological damage, such as reduced Intelligence Quotient (IQ) scores and reduced cognitive functions. The Panel on Contaminants in the Food (CONTAM Panel) determined a Limit of the Benchmark Dose and $1 \%$ extra risk $\left(\mathrm{BMDL}_{01}\right)$ of $12 \mu \mathrm{g} / \mathrm{L} \mathrm{B}-\mathrm{Pb}$ as a reference point for the risk characterisation of $\mathrm{Pb}$ when assessing the risk of intellectual deficits in children. The intake of $\mathrm{Pb}$ per unit of body weight is higher for children than for adults. Mainly because young children often place objects in their mouths, the physiological uptake rates of $\mathrm{Pb}$ in children are higher than in adults, and their organ systems are not fully developed (EFSA 2013; EC 2013). 
The main target organ for $\mathrm{Pb}$ toxicity is the central nervous system. In adults, $\mathrm{Pb}$ may affect central information processing, such as visuospatial organisation and short-term verbal memory. Relatively low-level exposure $(1.5 \mu \mathrm{g} / \mathrm{kg}$ body weight and day) and B-Pb levels above $36 \mu \mathrm{g} / \mathrm{L}$ are associated with elevated systolic blood pressure and chronic kidney disease (EFSA 2012a). Inorganic Pb compounds were classified by the IARC as probably carcinogenic to humans, group 2, on the basis of limited evidence of carcinogenicity in humans and sufficient evidence in animals (IARC 2006). Occupational exposures to inorganic $\mathrm{Pb}$ have been associated in a number of studies with elevated risk of cancer of the stomach, intestines, colon, rectum, lungs, brain, kidneys and bladder, and of leukaemia. The lack of smoking data and exposure pattern for $\mathrm{As}, \mathrm{Cd}$ and other metals in many of the studies made it difficult to separate the effects of $\mathrm{Pb}$ from the effect of other agents in the occupational environment (IARC 2006).

Lead in the blood is the most commonly used biomarker of exposure and body burden. $\mathrm{Pb}$ levels in bones and teeth reflect past exposure. Faeces for current gastrointestinal exposure and urine for organic $\mathrm{Pb}$ may be useful as biomarkers (Bergdahl \& Skerfving 2008).

\subsubsection{PCB}

Polychlorinated biphenyls (PCB) are a group of chemicals belonging to the persistent organic pollutants (POP) which have been released into the environment solely by human activity. They consist of carbon, hydrogen and chlorine atoms and there are 209 possible congeners, which can be divided in two groups according their toxicological properties. One group of 12 toxic congeners is dioxin-like PCBs (DL-PCB), which have a coplanar structure and show similar toxicological properties to dioxins (ATSDR 2000; EFSA 2005; EFSA 2012b; IARC 2018). These congeners with a toxic equivalence factor (TEF) according to the WHO are: PCB-77, PCB-81, PCB-105, PCB-114, PCB-118, PCB-123, PCB-126, PCB-169, PCB-156, PCB-157, PCB-167 and PCB-189 (IARC 2018). The other group of 197 congeners are nondioxin-like PCBs (NDL-PCB) and have a non-coplanar structure. The number of chlorine atoms and their locations in a PCB molecule determine its chemical and physical properties. All congeners are lipophilic and their lipophilicity increases with increasing degree of chlorination. They have low water solubility, and in the air they can travel long distances from the source of emissions; they can bio-accumulate in animals and bio-magnify in aquatic food chains (ATSDR 2000; EFSA 2005; EFSA 2012b; IARC 2018).

PCBs have been used commercially since 1929 by industry as heat-exchange fluids, in electric transformers and as additives in paint and plastics. Their extensive use in industrial applications is due to PCBs' chemical and physicals properties, such as chemical stability, non-flammability, high boiling point, low heat conductivity and high dielectric constants (Bernes 1998; EFSA 2012b). The manufacturing, processing and distribution of PCBs have been banned in Sweden since 1978 and PCB-containing materials have been banned since 1995. Although PCBs have now been banned in almost all industrial countries, their entry to the environment still occurs, due to leakage, redistribution and recycling in water, air and soil as well as global atmospheric transports. Deposited PCBs are also leaking from processes 
involving waste disposal and combustion and via jointing materials, they are leaking from buildings to the environment. Individual congeners undergo biodegradation and photodegradation, which results in a change in the mixture of congeners in the environment and their accumulation in animals. More highly chlorinated congeners of PCBs with certain chlorine patterns are more stable and accumulate in the food chain, while less chlorinated congeners are metabolized more quickly (EFSA 2005; EFSA 2012b; IARC 2018). Greater bioaccumulation occurs in fatty tissues (lipids) compared to muscle or the whole body of aquatic organisms. Fish with higher lipid concentrations, such as salmon trout, salmon, char and herring have a greater accumulated burden of PCBs (ATSDR 2000). In Sweden, elevated levels of dioxins and DL-PCBs occur in herring and in wild-caught salmonid fish (trout and salmon) from the Baltic Sea, Lake Vänern (trout and salmon) and from Lake Vättern (trout, salmon and char). The Swedish Environmental Protection Agency (SEPA) recommends that pregnant women and children should not eat these fish more than 2-3 times per year, due to the elevated levels of dioxins and DL-PCBs.

Humans are exposed to PCBs by inhalation, dermal absorption and the ingestion of food and contaminated soil/sediments. The main sources of PCB exposures in the general population are ingestion of fatty animal products, especially fatty fish, meat and dairy products (EFSA 2005; Bergqvist et al. 2008; EFSA 2012b; Bjermo et al. 2013; Darnerud et al. 2017). High consumption of fatty fish from contaminated waters can significantly increase consumers' dietary intake of PCBs. PCBs accumulate in breast milk and infants who are breast-fed may be exposed to increased levels of PCBs if the mother is a high consumer of contaminated fish (EFSA 2005; ATSDR 2000). PCBs pass through the placenta and are transferred to the foetus, but the body burdens are generally lower in the foetus than in the mother due to the lower blood lipid and body-fat content of the foetus. Infants who are entirely breast-fed have much higher PCB intake than adults, but breast-feeding has many additional advantages and these still outweigh the disadvantages. Fortunately, monitoring programmes have indicated a declining trend in PCB concentrations in breast milk during the last 20-25 years (EFSA 2005; Lignell et al. 2014; van der Berg et al. 2017; WHO 2017).

In adults, the consumption of fatty fish contributes to more than $60 \%$ of the average intake of PCBs and over $40 \%$ of dioxin-like PCBs. After risk-management efforts to minimize environmental pollution were introduced, human exposure to PCBs in Sweden has decreased by $4.5 \%$ per year during the period 1999-2015 (Darnerud et al. 2017).

Exposure to PCBs in both humans and animals has contributed to several adverse health effects. Endocrine-disrupting effects and changes in liver, dermal and ocular function have been associated with exposure to PCBs. Immunological alterations, neurodevelopment changes, reduced birth weight, reproductive toxicity, cardiovascular disease, diabetes and cancer have also been reported (EFSA 2005). In addition, DL-PCBs have been classified as carcinogenic to humans, group 1 (IARC 2018). It cannot be determined with certainty which congeners may have caused the adverse health effects, because general populations are exposed to a mixture of congeners as well as interactions between congeners and other chemicals (EFSA 2005). 
PCBs are absorbed from the gastrointestinal tract by passive diffusion. Distribution of PCBs in the body depends on the dose, structure and physicochemical characteristics of the individual congeners. There is an initial uptake in the liver and the muscles, and the more highly chlorinated congeners are then redistributed into adipose tissue and skin. Elimination of PCBs primarily occurs via the hepatic cytochrome P-450-dependent monooxygenase system through Ah-receptor-dependent or independent pathways. The excretion of PCB congeners depends on their rate of metabolism to more polar compounds. There is a large variation in half-lives (a few days to 10 years) between different congeners depending on the position and number of the chlorine atoms. The less-chlorinated PCBs are excreted to a greater extent via urine than the more highly chlorinated PCBs (EFSA 2005; EFSA 2012b).

PCBs in plasma or serum, maternal or cord blood, breast milk, adipose tissue and hair have been used as biomarkers for the exposure and body burden of PCBs. Concentration in blood lipids reflects the recent exposure and the full spectrum of congeners to which a person is exposed, while adipose tissue reflects long-term intakes. PCBs in breast milk reflect the concentrations of congeners in adipose tissue (EFSA 2005; IARC 2018). Lifestyle and medical factors, food habitat, residence, age, body mass index (BMI), weight change, gender and lactation may influence the serum/plasma concentrations of the different PCB congeners. These factors are related to several diseases and may be confounding factors in epidemiologic studies (Glynn et al. 2003).

\subsection{Health-risk assessments at contaminated sites}

In contaminated areas, low-level and long-term exposure to contaminants may have an adverse effect on human health. Indirect exposure by consumption of home-grown or locally produced food may be an important exposure route. Health risks associated with living in a contaminated area with potentially elevated exposure via the consumption of locally produced food are not well investigated. Knowledge concerning combined exposures and cumulative health risks is also scarce, but of great interest in risk assessments. The SEPA has developed a deterministic computational model for health-based guidance values for soil (SEPA 2009). This model is a good tool in risk assessment, but could be improved. The model takes into account direct soil exposure as well as indirect exposure from contaminants transported via the air, groundwater and plants. Fish consumption is included in the model, but not in the calculation of guidance values. Input data on exposure routes, such as consumption of locally produced food (vegetables, berries, mushrooms, fish, game, meat etc.) and tap-water (e.g. from private wells) is scarce (IMM 2011). Such data was gathered in connection with this thesis. 


\section{Aims of the thesis}

In this thesis, the Swedish national cancer registers and the FFQ are evaluated to determine whether they can identify health effects and risk categories of populations and whether the FFQ could be used as a tool in risk assessments. How well the questionnaire data reflects measured levels of biomarkers in human biological samples is also evaluated, along with whether consumption of local food from contaminated areas contributes to the total body burden of contaminants. The general aim is to increase knowledge and evaluate, through epidemiological and toxicological methods, the occurrence of cancer in populations residing in contaminated areas in relation to indirect exposure via long-term consumption of locally produced food, taking into account residential, occupational and lifestyles factors.

Furthermore, associations between reported local food consumption frequencies, biomarker concentrations and environmental and lifestyle factors are explored.

The specifics objectives were to discover:

- What health risks are associated with living in a contaminated area? (Papers I and III)

- What is the association between consumption of local food and risk of cancer? (Papers I and III)

- What factors affect exposure and dose? (Papers I-III)

- What is the association between measured levels of toxic substances in blood/urine and consumption of local food? (Papers II and III)

- How well does questionnaire data reflect measured levels in human biological samples? (Papers II and III)

- Can cancer be identified in populations living in contaminated areas? (Papers I-III)

- Are populations residing in contaminated areas more exposed than others? (Papers II and III)

- How can questionnaires be used as a tool in health-risk assessments? (Papers II and III) 


\section{Subjects and methods}

All three papers follow the same general methodology, but with the aim of gradually validating and improving the methods. The following is a summary of the study areas, study population and methods used in this thesis. The general design for the characterization of human environmental exposure to site-specific pollutants is presented in Figure 5. A short summary of the study design of the different papers is presented in Figure 6. Further details can be found in the individual papers (Papers I-III).

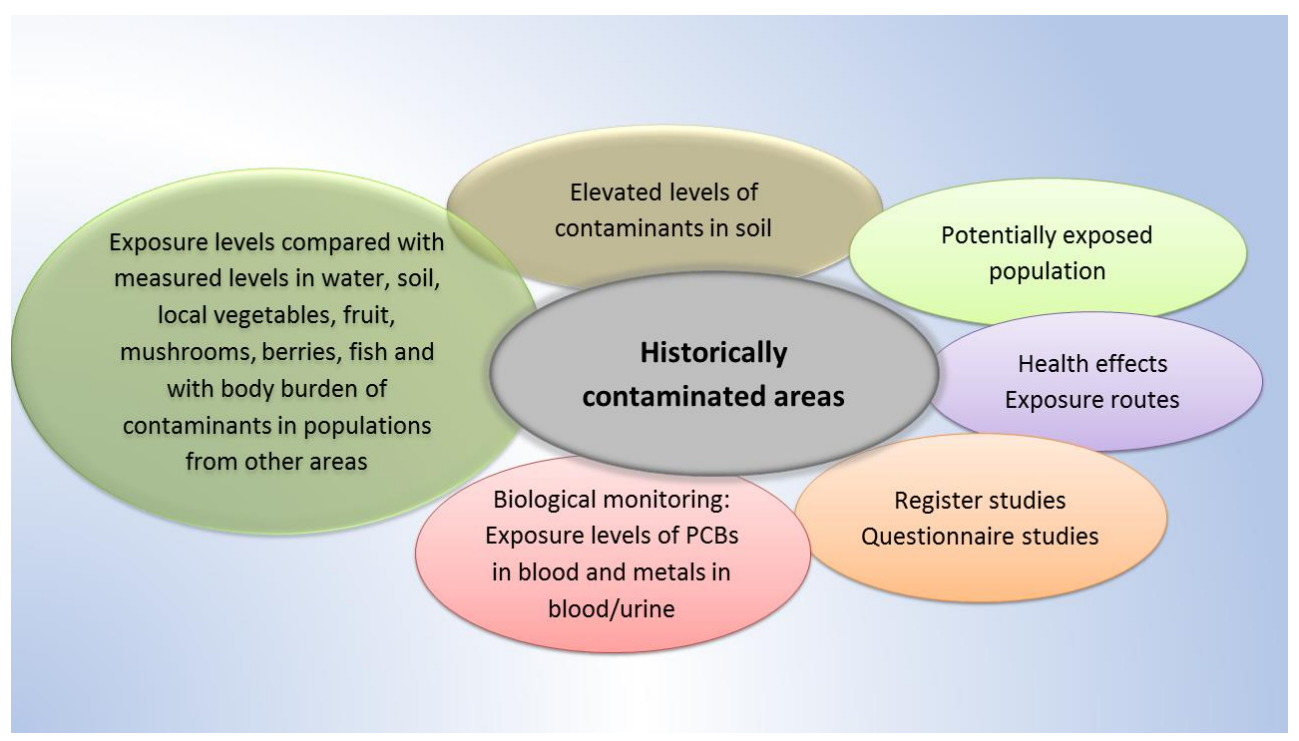

Figure 5: The general design for the characterization of human environmental exposure to sitespecific pollutants in populations living in historically contaminated areas and the evaluation of the associations between environmental pollutant concentrations, exposure levels and observed or reported health effects. 


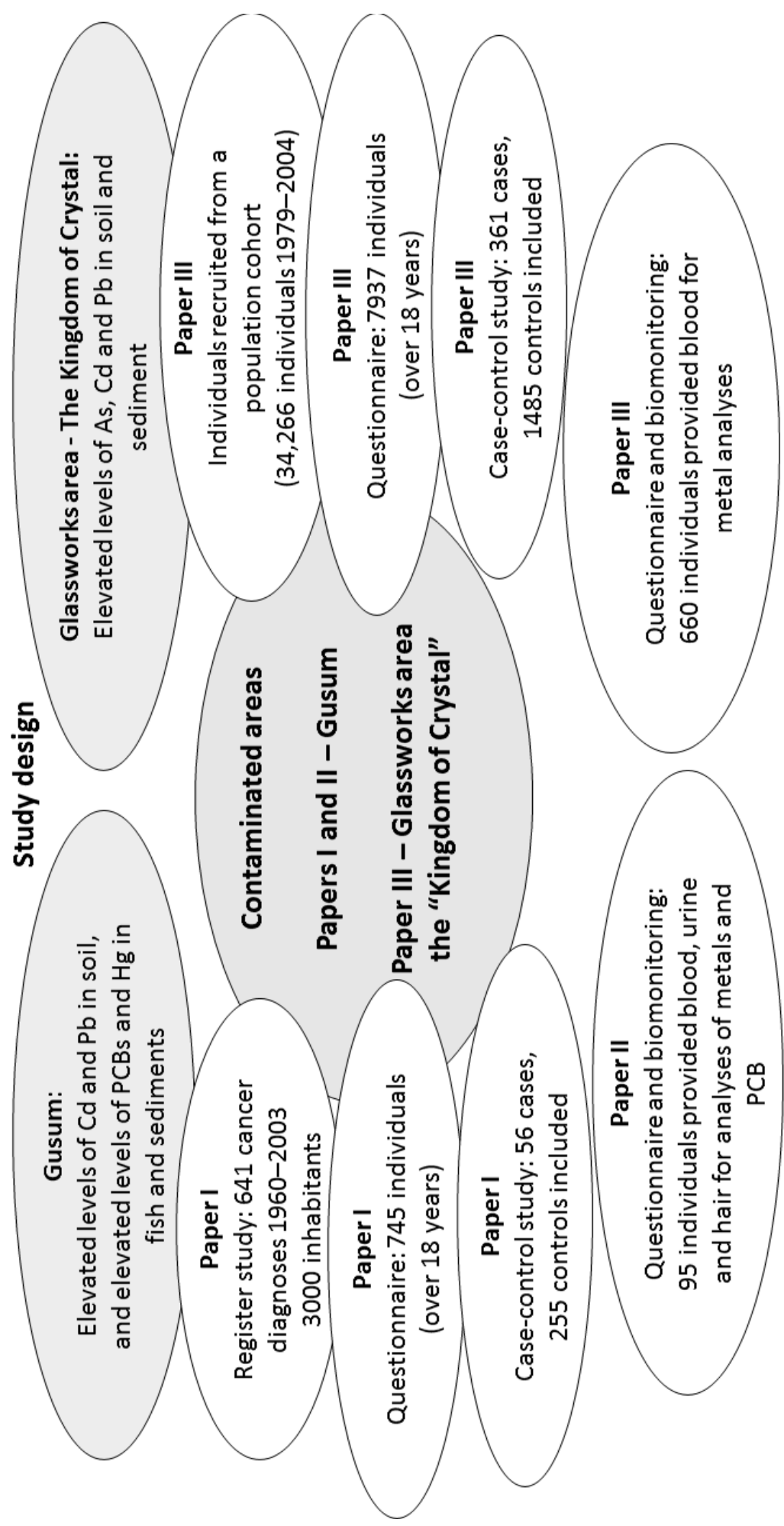




\subsection{Study areas}

The study areas were located in Gusum (Figure 7) in the County of Östergötland and in Nybro and Emmaboda (Figure 8) municipalities in the County of Småland. Both areas were highly contaminated due to industrial activities over many decades. These areas have been investigated by local authorities and there are plans to decontaminate them. In collaboration with local authorities, there have been several meetings with discussions and exchanges of experiences, and the local authorities have contributed with historical environmental data. Additional information and the history of the contaminated areas are described in the section Background.

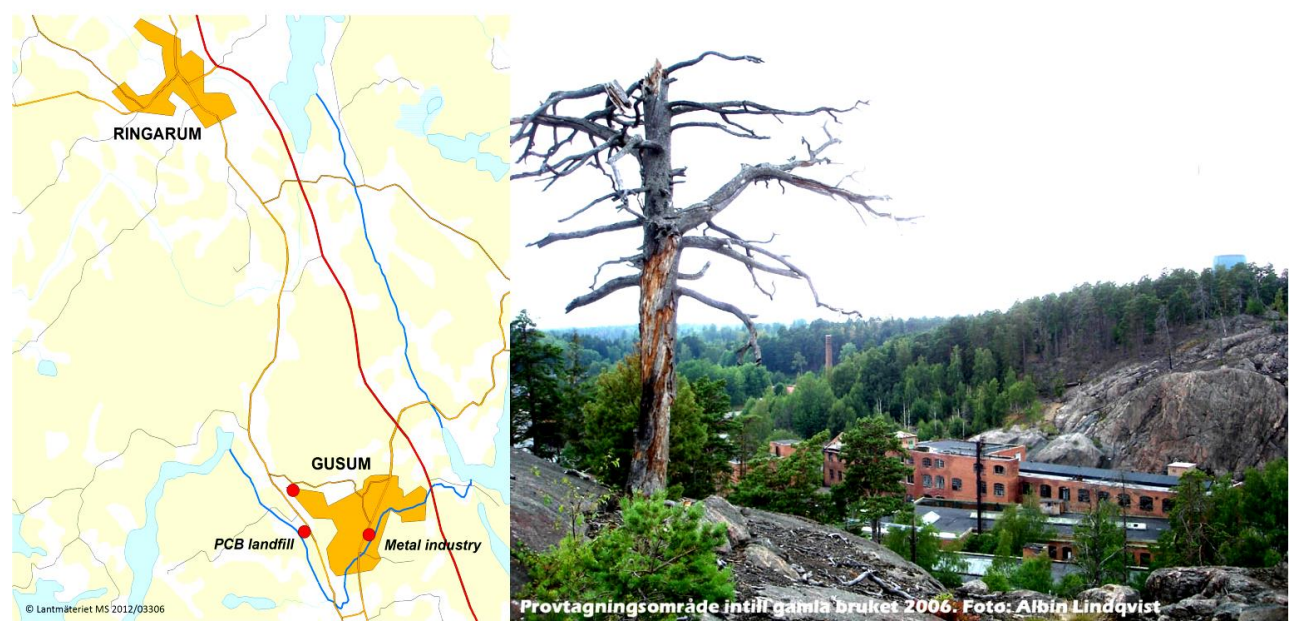

Figure 7. On the left, a map of the Gusum/Ringarum parish area, in Sweden. On the right, a view across the old metal industry site in the village of Gusum.

\subsection{Study population and questionnaires}

\subsubsection{Gusum}

Paper I is based on two epidemiological sub-studies of a small population, about 3000 inhabitants during the study period. 1) During 2004, a register-based study was performed in the parish of Gusum/Ringarum where the contaminated area is situated. 2) This register-based study was followed by a questionnaire-based case-control study in 2005 .

In the register study, we identified 120 cancer cases still alive at the time of dispatch of the questionnaire (Appendix 1) and who, together with 625 randomly selected controls. Cases and controls aged over 18 years received a questionnaire with questions regarding demographic factors, lifetime residences, lifetime occupations, smoking habits, medical history, number of children, birth weight, gestation, prior and present consumption of local food (frequencies and type of fish, vegetables, berries and mushrooms). High consumption of local food was defined as more than twice a month for fish, wild berries or mushrooms, and as more than three times a week for garden vegetables, based on reported consumption frequencies for the previous 30 
years (1975-2004). The non-consumers in this study had reported never consuming local food.

Paper II is based on the long-term consumption data (1975-2004) available from the questionnaire in combination with biological monitoring in 2008 of consumers and nonconsumers of local food identified from the case-control study in Paper I. A letter was sent to the 164 identified individuals and they were asked to provide blood, urine and hair samples for analysis of levels of PCBs, pesticides, lead, cadmium and mercury, and to answer an additional questionnaire (Appendix 2) concerning consumption frequencies of food and factors relating to lifestyle and exposure. This questionnaire was a complementary addition in order to explore any large changes in food habits and to explore the degree of intra-individual correlations between reported food consumption and time variables. The time variables, including age, gender, smoking habits, occupation, drinking-water source, self-reported medical history and cancer diagnoses, were evaluated in relation to consumption frequencies of local food and measured concentrations of environmental contaminants in the blood, urine and hair. Two new questions were introduced, one on the frequency of pesticide use, occupationally or at home, and one on any major weight changes during the previous three months, since this may influence the levels of persistent organic chemicals in plasma.

\subsubsection{Glassworks area: "The Kingdom of Crystal"}

Paper III includes an evaluation of epidemiological and toxicological methodologies from Papers I and II. The study population was recruited from a register study cohort (Nyqvist et al., 2017), and includes a potentially exposed population in Nybro and Emmaboda. This population cohort, involving 34266 individuals, was identified, using Geographic Information System (GIS), as residing within a $2 \mathrm{~km}$ radius (the "exposure area") of an emission source (glassworks or glass landfill) (Figure 8).

In this cohort study, a case-control study was performed to evaluate the associations between intake of local food and human health effects, taking into account modifying factors and covariates. All identified cancer cases aged over 18 years (1200) in the register study were approached, along with a random sample of cancer-free control individuals (7000) living in the same area during the same time period as the diagnosed cancer cases. An invitation/information letter containing unique login information and a link to an online questionnaire (Appendix 3) was sent to a total of 7939 cohort members, aged over 18 years and still alive at the time of dispatch in 2014. Since the last dispatch in the previous study in Gusum, the questionnaire had been modified, in light of the earlier experience and communications with an expert in how to perform questionnaire studies at Linköping University.

Information was collected on lifetime residency, lifetime occupations, smoking habits, number of child births, anthropometric data, personal and parental medical history, and extensive qualitative and quantitative information on prior (the previous 20-30 years) and present consumption of local and other food items (frequencies and type of fish, meat, 
vegetables, fruit, garden and forest berries, mushrooms and drinking-water source, e.g. private well or public water). The food intake frequencies in the questionnaire were grouped into five categories, in order to facilitate respondents.
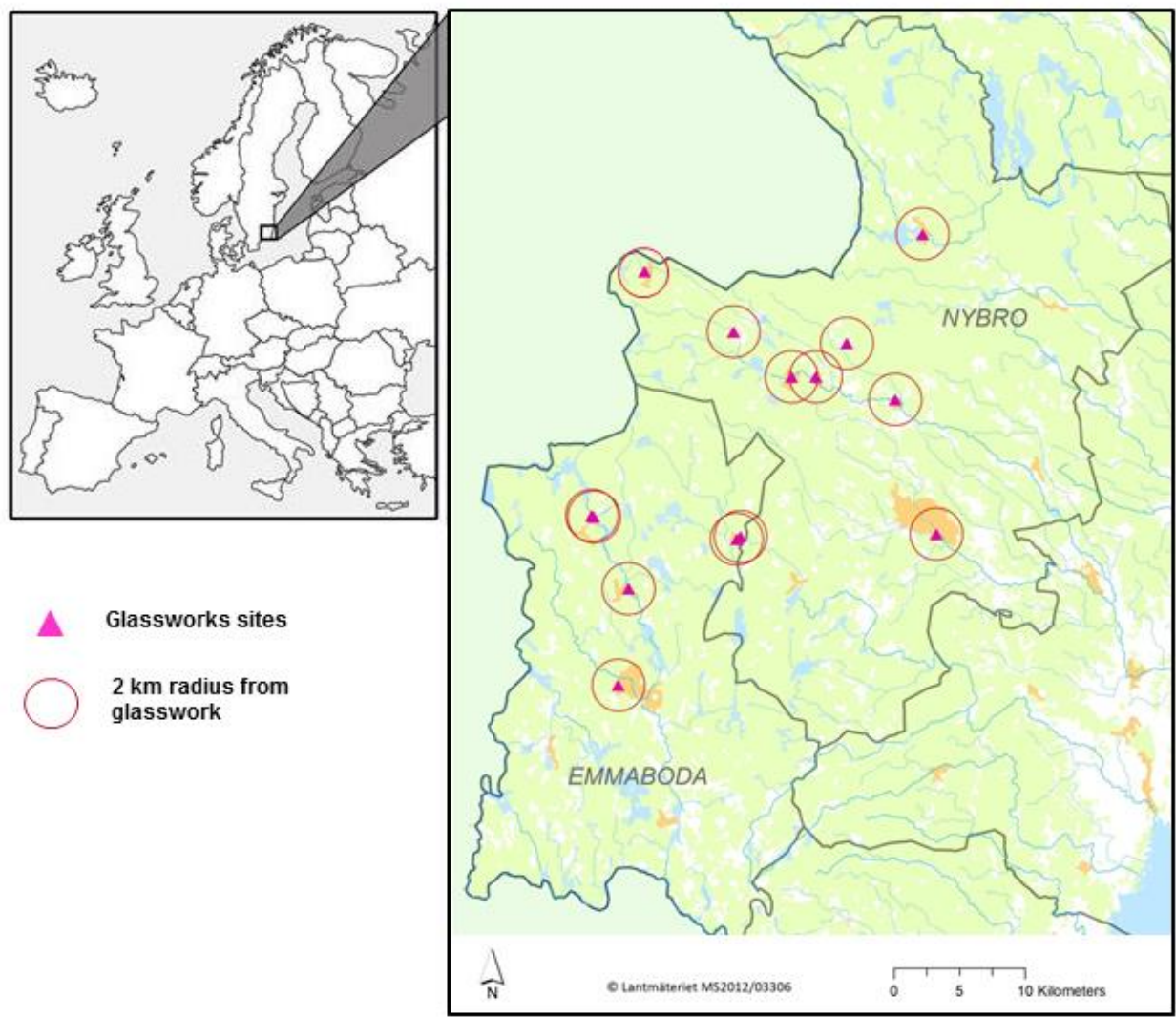

Figure 8. Map of the glassworks area in Nybro and Emmaboda municipalities, in Sweden. The circles indicate a $2 \mathrm{~km}$ radius from an emission source (glassworks or glass landfill).

\subsection{Biological sample collection}

In order to assess the long-term exposure and body burden of contaminants (Papers II and III), we used biomarkers of $\mathrm{Cd}$ (in urine, blood) and $\mathrm{Pb}$ (blood), $\mathrm{Hg}$ in hair (Paper II), As in blood, PAH-metabolite 1-hydroxipyren (1-OHPy) in urine (Paper III) and PCBs (Papers II and III) and organochlorine pesticides in plasma (Paper II). The experience of biological sample collection methods in Paper II has been evaluated and improved upon in Paper III. We have also evaluated and improved upon the methods together with the National Food Agency in its national biomonitoring study funded by the Swedish Civil Contingencies Agency and the national study of eating habitats among youths (National Food Agency 2017).

For Paper II, a letter was sent out after the first questionnaire dispatch to inform the participants about the study and to ask them to provide biological samples. For Paper III, we 
invited the study participants to take part in the biomonitoring study through the questionnaire in order to reduce mail dispatch and save a lot a time. The participants were invited to donate blood and urine samples, as well as samples from their private well water and home-grown vegetables, berries, mushrooms, etc., as appropriate. The participants who lived within a limited geographical distance (about $50 \mathrm{~km}$ ) of Nybro and Emmaboda municipalities were contacted by a nurse.

Specially prepared first-void morning urine home sample kits (urine cups, 2 urine tubes) and detailed instructions were mailed to the recruited participants prior to the sampling. The urine cups were tested for metal contamination and the urine tubes were acid washed. For Paper II, blood was collected in four $10 \mathrm{~mL}$ vacuum tubes for the analyses of PCBs and organochlorine pesticides. Plasma was separated from whole blood and stored in acid-washed dark glass bottles.

For the metal analyses in Paper II, blood was collected in one $5 \mathrm{~mL}$ Sodium-Heparin vacuum tube. For Paper III, blood was collected in two $4 \mathrm{~mL}$ Natrium-Heparin vacutainer tubes due to instructions from the different laboratories that performed the analyses. All samples were kept frozen in a portable freezer bag $\left(-18^{\circ} \mathrm{C}\right)$ for transport to the laboratory and stored in a freezer $\left(-20^{\circ} \mathrm{C}\right.$ or $\left.-80^{\circ} \mathrm{C}\right)$ prior to the analyses. Full-length hair samples were tied and cut close to the scalp from the back of the head and put into plastic bags. The hair samples (Paper II) were stored at room temperature until the time of analysis for $\mathrm{Hg}$.

\subsection{Biological sample analyses}

For Paper II, the metal analyses were performed at the Institute of Environmental Medicine, Karolinska Institute, Stockholm. The researchers used inductively coupled plasma mass spectrometry (ICPMS; Agilent 7500ce, Agilent Technologies, Waldbronn, Germany) with a collision/reaction cell system. In order to minimize the influence of possible interferences, an ICPMS autosampler (ASX-500 series: Agilent Technologies, USA) and a quartz MicroMist nebulizer were used. Cadmium $\left({ }^{111} \mathrm{Cd}\right)$ was measured in helium mode, and mercury $\left({ }^{201} \mathrm{Hg}\right)$ and lead $\left({ }^{208} \mathrm{~Pb}\right)$ in standard mode. Concentrations of $\mathrm{Cd}$ in urine were density adjusted to the average urine-specific gravity of $1.016 \mathrm{~g} / \mathrm{mL}$. Specific gravity in urine was measured using a refractometer (Uricon-Ne, ATAGO Co. Ltd. Tokyo, Japan).

PCBs and organochlorine pesticides for Paper II and Paper III were analysed at the MTM laboratory at Örebro University. In total, 18 POPs were measured in plasma: 14 PCB congeners (PCB 74, 99, 105, 118, 138, 153, 156, 157, 170, 180, 189, 194, 206 and 209) and four pesticides (hexachlorobenzene/ $\mathrm{HCB}$, trans-chlordane, trans-nonachlor, $\mathrm{pp}^{\prime}-$ dichlorodiphenyldichlorethylene/DDE). Plasma concentrations of organochlorine compounds were lipid adjusted. Plasma lipids were determined at the department of Laboratory Medicine, Örebro County Council.

For Paper III, the metal and PAH metabolite 1-OHPy analyses were performed at the Department of Occupational and Environmental Medicine, Linkoping University. All samples for the metal analysis were analysed using a standard ICP-MS benchtop instrument HP 4500 
series 100 (Agilent Technologies Inc.) operated with Pt-tip and skimmer cones. The metal elements ${ }^{60} \mathrm{Ni},{ }^{208} \mathrm{~Pb}$ (the sum of three isotopes: 206, 207 and 208), ${ }^{111} \mathrm{Cd},{ }^{121} \mathrm{Sb},{ }^{75} \mathrm{As},{ }^{59} \mathrm{Co}$ and ${ }^{202} \mathrm{Hg}$ were analysed in urine and whole blood. Metal concentrations in the urine samples were individually creatinine adjusted in order to account for variations in urine dilution. Urine creatinine was determined at the Clinical Chemistry laboratory, Linkoping University Hospital. Due to the large amount of data, only $\mathrm{Cd}$, $\mathrm{As}$ and $\mathrm{Pb}$ in blood were evaluated in Paper III, and in order to explore potential health effects due to concurrent exposure to POPs and PAH, PCB118, PCB153 and 1-OHPy were also evaluated. The rest of the data will be evaluated in future studies.

In all the analyses, well-characterized quality-control references were used. In general, the results of all the reference materials were in good agreement with the reference values. Further details can be found in the respective papers (Papers II and III).

\subsection{Ethics}

All the studies were approved by the regional Ethical Committee at Linköping University, Sweden. Oral and written informed consent regarding participation in the questionnaire and biomonitoring studies was obtained from all participants. The individual results from the analyses of blood and urine were only reported to the participants who announced that they wanted to receive them. In these cases, the participants were informed in a letter that we would need to re-identify their individual serial/sample number. Then the participants received a personal letter with brief information about the results, and reference values if appropriate.

\subsection{Statistics}

The statistical analysis in Paper I was performed in STATA version 11 (Statistical Software StataCorp LP, USA). The number of observed cancers in the studied area was compared to expected numbers, calculated from incidence rates within the general Swedish population. Standardized incidence ratios (SIR) with $95 \%$ confidence intervals (CI), adjusted for age and calendar year, were calculated. Odds ratios (OR) with $95 \%$ confidence intervals, using a latency requirement of $>5$ years of residence before cancer diagnosis or inclusion in the study (controls), were calculated for the evaluation of associations between exposure variables and cancer.

Based on the reported consumption frequencies over the previous 30 years, high consumption of local foods was defined as more than twice a month for fish, wild berries or mushrooms, and more than three times a week for garden vegetables. Potential occupational exposure to the contaminants of interest was evaluated based on the occupational groups of ever being a farmer or metal worker. Univariate analyses were performed for total cancer and for specific cancers. Due to the limited number of cancer cases and the strong correlations between variables, multiple logistic regressions, Mantel-Haenzel (M-H) OR, were only performed for total cancers as the outcome and the strongest determinants for risk found in the univariate 
analyses. Since the controls were not individually age-matched to the cases, all analyses were adjusted to age as a continuous variable. A non-response analysis was carried out based on the number of returned questionnaires.

In Paper II, the statistical analyses were performed in STATISTICA 10 (StatSoft@), Oklahoma USA). The Mann-Whitney U test was used to evaluate differences in consumption frequencies between genders, cancers and controls. Spearman correlation coefficients (rs) were used to assess the associations between concentrations of measured contaminants and frequencies of consumption. Two consumption groups (non-consumers, consumers) of local fish (consumers $\geq$ twice/year), vegetables, fruit, berries and mushrooms (consumers $\geq 6$ times/year) were constructed.

In order to account for the influence of other factors, we performed multivariate adjusted analyses in Papers II and III. Multivariate analysis NIPALS/PCA (Nonlinear Iterative Partial Least Squares/Principal Component Analysis) was used to assess the pattern of exposure and co-variations for reported consumption of local food, measured concentration of contaminants in blood, urine and hair, and selected variables that may affect the results. Factors with eigenvalues greater than 1 (Kaiser Method) were included in the PCA analysis and a Scree plot (Cattel's criterion) was used to graphically determine the optimal numbers of factors to retain.

In this thesis, a complementary PCA analysis was performed based on the questionnaire data collected for Paper II. Three consumption groups (high, intermediate, non) were constructed. High consumption of local vegetables, fruit, garden and forest berries and mushrooms was defined as $\geq$ twice/week, intermediate as <twice/week-6 times/year. High consumption of locally caught fish was defined as $\geq$ twice/month, intermediate as $<$ twice/month-twice/year. Non-consumers had reported never consuming locally produced food.

A main effect analysis of variance (ANOVA), followed by a Post Hoc test, Bonferroni, was used to evaluate mean differences between groups, when the level of concentration of contaminants in blood and/or urine in relation to the consumption frequencies of locally produced foods were evaluated. Variables to be included in the multiple ANOVA models were selected based on the PCA analyses. The statistical significance level was set at $\mathrm{p}<0.05$.

All statistical analyses in Paper III were performed in STATISTICA 64, version 13 (Statsoft ${ }^{\odot}$, Oklahoma USA). The Pearson chi-square test and one-way ANOVA were used to assess differences between groups and between continuous variables (age, residence time), respectively.

Based on the reported consumption frequencies over the previous 20-30 years, three groups of consumers (non/seldom, intermediate and high) were formed. High consumption of local vegetables, fruit and berries was defined as more than once/week, high consumption of local meat and fish was defined as more than once/month. Intermediate consumption was defined as 3 times/year to 4 times/month for local vegetables and 3-11 times/year for local meat and fish. Seldom/never was defined as non/low consumer. Potential occupational exposure to the 
metals of interest was evaluated based on job title information, being a glass worker or a metal worker.

PCA and main effect ANOVA (Bonferroni) were used to evaluate associations between groups and concentrations of metals in the biomonitoring study. Concentrations of metals $(\mathrm{Cd}, \mathrm{Pb}, \mathrm{As})$ in blood and urine were used to validate the Food Frequencies Questionnaire (FFQ), which was later used in the case-control study.

In the case-control study, only subjects with a requirement of at least 5 years of residence time in a glassworks area (cases and controls) and a latency time requirement of at least 10 years before cancer diagnosis (cases) or inclusion in the study (controls), were included in the statistical analyses. In order to assess associations between several influencing factors and total cancer and specific cancers in Paper III, we performed univariate and bivariate logistic regression analyses. Multivariate logistic regression was used to study the association between consumption of local food frequencies and cancer and the covariates age, gender, family history of cancer, education level, obesity and residence in a glassworks area during the first five years of life. Based on the bivariate logistic regression analyses, the criterion for covariates to be entered in the multivariate-adjusted model was $\mathrm{p} \leq 0.20$.

Power calculations on study size (Papers II and III) were performed in OpenEpi, Dean AG, Sullivan KM, Soe MM (Open Source Epidemiologic Statistics for Public Health, Version 3, Sample size for unmatched case-control study, Power for unmatched case-control studies, Sample size for comparing two mean and Power for comparing two means www.OpenEpi.com, updated 2013/04/06). 


\section{Results and discussion}

\subsection{Health risks associated with living in a contaminated area (Papers I and III)}

Living in a contaminated area may pose a potential health risk. In this thesis, it is primarily the cancer risk that has been evaluated, but several of the identified contaminants have been shown to also be associated with other health effects. Additional health effects reported in the collected questionnaires, such as heart disease, diabetes, kidney damage, osteoporosis and neurological effects, will be evaluated in future studies.

In the register-based study of the Gusum population (Paper I), the total cancer incidence was non-significantly lower among both males and females than national rates for each gender (Table 1). Among males, a significantly decreased cancer incidence was seen for cancer of the rectum, respiratory system and brain. This is in accordance with a lower incidence of several cancers reported for rural compared to urban areas (Bidoli et al. 1998; Ocaña-Riola et al. 2004; Chen et al. 2015). On the other hand, a higher incidence of testicular cancer and lymphomas among males in the study area was found, which may indicate exposure to hazardous substances.

Table 1. Key findings from the observed (Obs) cancer incidences in the study area (Gusum), as compared to expected (Exp) numbers calculated from incidences in the general Swedish population for the years 1960-2003. Standardized Incidence Ratios (SIR) adjusted for age and calendar year, and $95 \%$ confidence intervals (CI). Data are presented for forms of cancer with at least 5 observed cases among males or females. Significant SIRs are visualized in bold.

\begin{tabular}{llllllll}
\hline Cancer form & ICD7 & Men & \multicolumn{5}{l}{ Female } \\
\hline & & Obs. & Exp. & SIR (95 \% CI) & Obs. & Exp. & SIR (95 \% CI) \\
\hline All sites & $140-209$ & 346 & 382 & $0.91(0.78-1.05)$ & 295 & 324 & $0.91(0.77-1.07)$ \\
Rectum & 154 & 10 & 18.6 & $\mathbf{0 . 5 4}(\mathbf{0 . 2 5}-\mathbf{0 . 9 9 )}$ & 12 & 12.6 & $0.95(0.49-1.66)$ \\
Bronchus and lung & 162.1 & 22 & 34.5 & $\mathbf{0 . 6 4}(\mathbf{0 . 4 0 - 0 . 9 7 )}$ & 6 & 12.2 & $0.49(0.18-1.08)$ \\
Respiratory system & $160-164$ & 24 & 41.8 & $\mathbf{0 . 5 7}(\mathbf{0 . 3 6}-\mathbf{0 . 8 6})$ & 7 & 14.1 & $0.50(0.20-1.03)$ \\
Testis & 178 & 7 & 2.84 & $2.46(0.99-5.08)$ & & & \\
Brain & 193.0 & 3 & 9.61 & $\mathbf{0 . 3 1}(\mathbf{0 . 0 6 - 0 . 9 1 )}$ & 13 & 9.51 & $1.37(0.72-2.34)$ \\
Lymphomas & $200-202$ & 22 & 13.8 & $1.60(\mathbf{1 . 0 0 - 2 . 4 2 )}$ & 8 & 9.68 & $0.82(0.35-1.63)$ \\
\hline
\end{tabular}

In previous register studies in the glassworks area, significantly elevated cancer incidences were observed for brain cancer (Wingren \& Axelsson 1992) and total cancer, as well as cancer of the digestive system, prostate, lymphatic and hematopoietic system (Nyqvist et al. 2017). In addition, Nyqvist et al. (2017) found a dose-response relationship between the levels of $\mathrm{Cd}$ and $\mathrm{Pb}$ in soil (low, medium, high contamination) and total cancer, digestive system and prostate cancer. In the present case-control study of the population in the same area (Paper III), we found a significant association between increased risk of total cancer and cancer of the digestive system and residing in a glassworks area during the first five years of life (Table 2). When stratifying by gender, residing in a glassworks area during the first five years of life was associated with significantly increased risk of total cancer and cancer of the digestive system in women only, while men had significantly decreased risk of prostate 
cancer. In Paper I, a non-significantly increased total cancer risk was seen for men living in the study area during their first five years of life ( $\mathrm{OR}=3.01$; $\mathrm{CI}=0.94-9.61)$.

These results may be explained by increased exposure to contaminants in early life. It has been suggested in earlier studies that foetuses and children are more vulnerable than adults to toxic chemicals in the environment (Landrigan \& Goldman 2011; Leith \& Carpenter 2012; Felter et al. 2015). Therefore, environmental contaminant exposure during the first five years of life may contribute to the increased risk of cancer later in life.

Table 2. Logistic regression analyses in relation to residing in a glassworks area during the first five years of life and with total cancer and specific cancer variables. Restriction criteria of at least 5 years of residence time in the contaminated area and a latency time of at least 10 years between first residence year and time of cancer diagnosis (cases) or inclusion in the study (controls) were applied. Significant $O R s$ and $p$-values in bold.

\begin{tabular}{|c|c|c|c|c|c|c|}
\hline Cancer ICD: & $\begin{array}{l}\text { Gender (number } \\
\text { of cases) }\end{array}$ & $\begin{array}{l}\text { Number of } \\
\text { exposed cases }\end{array}$ & $\begin{array}{l}\text { Number of } \\
\text { exposed } \\
\text { controls }\end{array}$ & $\mathrm{OR}^{\mathrm{a}}$ & $95 \% \mathrm{Cl}$ & p-value \\
\hline \multirow[t]{3}{*}{ Total cancer } & Both $(n=361)$ & 157 & 772 & 1.33 & $1.02-1.72$ & 0.03 \\
\hline & Men $(n=174)$ & 67 & 366 & 0.97 & $0.67-1.41$ & 0.88 \\
\hline & Women $(n=187)$ & 90 & 406 & 1.75 & $1.22-2.52$ & 0.002 \\
\hline Digestive system & Both $(n=41)$ & 21 & 772 & 2.00 & $1.04-3.89$ & 0.04 \\
\hline \multirow[t]{2}{*}{ (ICD7: 151-154) } & Men $(n=21)$ & 8 & 366 & 0.95 & $0.38-2.39$ & 0.91 \\
\hline & Women $(n=20)$ & 13 & 406 & 4.68 & $1.69-12.9$ & 0.003 \\
\hline Kidney (ICD7: 180) & Both $(n=9)$ & 6 & 772 & 4.13 & $0.99-17.4$ & 0.05 \\
\hline $\begin{array}{l}\text { Female genital cancer } \\
\text { (ICD7: 170-175) }\end{array}$ & Women $(n=98)$ & 44 & 406 & 1.59 & $0.99-2.55$ & 0.05 \\
\hline Female breast cancer (ICD7: 170) & Women $(n=75)$ & 33 & 406 & 1.62 & $0.96-2.75$ & 0.07 \\
\hline $\begin{array}{l}\text { Male genital cancer } \\
(\text { ICD7: } 177-178)\end{array}$ & Men $(n=79)$ & 22 & 366 & 0.59 & $0.34-1.03$ & 0.06 \\
\hline Prostate cancer (ICD7: 178) & Men $(n=73)$ & 19 & 366 & 0.55 & $0.30-0.98$ & 0.04 \\
\hline
\end{tabular}

${ }^{\mathrm{a}} \mathrm{OR}=\mathrm{Odds}$ Ratio, $\mathrm{Cl}=$ Confidence Interval, adjusted for age

\subsection{Association between consumption of local food and risk of cancer (Papers I and III)}

It was hypothesized that living in a contaminated area and consuming locally produced foods will increase the risk of cancer. Food consumption is the main route for the intake of a mixture of contaminants (WHO 2010; IARC 2012b; EFSA 2012a; EFSA 2012b). Long-term consumption of local food from contaminated areas may contribute to higher exposure to contaminants and thereby an increased risk of cancer. Despite former local dietary recommendations in Gusum (Paper I), more than $80 \%$ of the population in the case-control study reported some consumption of local food during 1975-2005, while about $75 \%$ of the study population in the glassworks area (Paper III) reported some consumption of local food during the previous $20-30$ years. 
In the questionnaire-based study (Paper I), with both genders combined, significant associations were found for total cancer and high consumption of local perch, as well as for lymphomas and high consumption of both perch and pikeperch (Table 3). Female breast cancer was significantly associated with high consumption of local perch and pike.

Table 3. The main results from case control evaluations for the association between exposure variables (consumption of local food) and total cancer and specific forms of cancer in the study area (Gusum) during the period 1960-2003, adjusted for age and with a latency requirement of $>5$ years of residence before the cancer diagnosis (cases) or inclusion in the study (controls). Significant ORs visualized in bold.

\begin{tabular}{|c|c|c|c|c|}
\hline & Exposure variable & $\begin{array}{l}\text { Exposed } \\
\text { case/controls }\end{array}$ & $\mathrm{OR}^{\mathrm{a}}$ & $95 \% \mathrm{Cl}^{\mathrm{a}}$ \\
\hline \multicolumn{5}{|l|}{ Total cancer } \\
\hline Both genders & Perch $>$ twice per month vs never ${ }^{b}$ & $8 / 8$ & 3.89 & $1.20-12.5$ \\
\hline Lymphoma (ICD7 200-201, 5 cases) & Perch > twice per month vs never ${ }^{b}$ & $2 / 8$ & 37.6 & 2.38-595 \\
\hline Both genders & Pikeperch $>$ twice per month vs never ${ }^{b}$ & $2 / 7$ & 13.8 & $1.54-124$ \\
\hline \multicolumn{5}{|l|}{ Breast cancer (ICD7 170, 14 cases) } \\
\hline \multirow[t]{2}{*}{ Female } & Perch > twice per month vs never ${ }^{b}$ & $2 / 5$ & 7.90 & $1.01-61.9$ \\
\hline & Pike > twice per month vs never ${ }^{b}$ & $2 / 6$ & 9.07 & $1.10-74.4$ \\
\hline
\end{tabular}

${ }^{\mathrm{a}}$ OR=Odds Ratio, $\mathrm{Cl}=$ Confidence Interval

${ }^{b}$ Mean consumption of local food item during the last 30 years.

Also in the questionnaire-based study (Paper III), significant associations were found between long-term high consumption of locally caught fish and total cancer and male genital cancer (Table 4). Also, long-term high consumption of locally produced chicken, lamb and local game meat was associated with increased risk of digestive cancer.

It has to be pointed out that reported long-term high consumption of non-local food from places outside the study areas (Papers II and III) were not associated with increased risk of cancer. The associations between long-term consumption of local fish (Papers II and III) and local game meat, lamb, chicken (Paper III) and different types of cancer may reflect a higher exposure in the past, and thus, if consumption of locally produced food contributes to the risk of acquiring cancer, that risk is most probably lower today than previously. 
Table 4. Case-control analyses for the association between consumption of local food (high consumption vs never or seldom) and total cancer, cancer of the digestive system (ICD7: 151-154), cancer of the brain, nervous system (ICD7: 193) and male genital cancer (ICD7: 177-178), adjusted for covariates, and with a requirement of at least 5 years of residence time in the contaminated glasswork area (cases and controls) and with a latency time requirement of at least 10 years before cancer diagnosis (cases) or inclusion in the study (controls). Based on the bivariate logistic regression analyses, the criterion for covariates to be entered in the multivariate-adjusted model was $p \leq 0.20$. Odds ratios (OR) and $95 \%$ confidence intervals $(\mathrm{Cl})$ are presented for outcomes significantly different from unity. Significant ORs and $p$-values in bold.

\begin{tabular}{|c|c|c|c|c|c|c|c|c|}
\hline \multirow{2}{*}{$\begin{array}{l}\text { Exposure/ } \\
\text { consumption }\end{array}$} & \multicolumn{4}{|c|}{ Logistic regression } & \multicolumn{4}{|c|}{ Multivariate logistic regression } \\
\hline & $\begin{array}{l}\text { Exposed } \\
\text { cases/controls }\end{array}$ & OR $^{\mathrm{a}}$ & $95 \% \mathrm{Cl}$ & p-value & $\begin{array}{l}\text { Exposed } \\
\text { cases/controls }\end{array}$ & OR ${ }^{b}$ & $95 \% \mathrm{Cl}$ & p-value \\
\hline \multicolumn{9}{|l|}{ Total cancer } \\
\hline $\begin{array}{l}\text { Salmon, salmon } \\
\text { trout, whitefish }\end{array}$ & $19 / 42$ & 1.82 & $1.14-2.92$ & 0.01 & $17 / 40$ & 1.77 & $1.07-2.92$ & 0.03 \\
\hline \multicolumn{9}{|c|}{ Digestive system cancer } \\
\hline $\begin{array}{l}\text { Game meat, } \\
\text { chicken, lamb }\end{array}$ & $10 / 180$ & 2.01 & $1.07-3.74$ & 0.03 & $8 / 165$ & 2.21 & $1.09-2.86$ & 0.03 \\
\hline \multicolumn{9}{|l|}{ Rectum cancer } \\
\hline $\begin{array}{l}\text { Game meat, } \\
\text { chicken, lamb }\end{array}$ & $6 / 180$ & 2.92 & $1.16-7.36$ & 0.02 & $5 / 165$ & 3.47 & $1.25-9.66$ & 0.02 \\
\hline \multicolumn{9}{|c|}{ Brain and nervous system } \\
\hline $\begin{array}{l}\text { All consumption of } \\
\text { local lamb }\end{array}$ & $5 / 127$ & 2.62 & $1.34-5.14$ & 0.004 & $5 / 124$ & 2.65 & $1.34-5.24$ & 0.005 \\
\hline \multicolumn{9}{|l|}{ Men } \\
\hline & $\begin{array}{l}\text { Exposed } \\
\text { case/control }\end{array}$ & $O^{c}$ & $95 \% \mathrm{Cl}$ & p-value & $\begin{array}{l}\text { Exposed } \\
\text { cases/controls }\end{array}$ & $O R^{d}$ & $95 \% \mathrm{Cl}$ & p-value \\
\hline \multicolumn{9}{|l|}{ Male genital cancer } \\
\hline Forest berries & $8 / 63$ & 0.66 & $0.36-1.23$ & 0.19 & $8 / 60$ & 0.69 & $0.36-1.29$ & 0.25 \\
\hline $\begin{array}{l}\text { Salmon, salmon } \\
\text { trout, whitefish }\end{array}$ & $9 / 19$ & 2.52 & $1.48-4.31$ & $<0.001$ & $8 / 18$ & 2.40 & $1.35-4.25$ & 0.003 \\
\hline \multicolumn{9}{|l|}{ Prostate cancer } \\
\hline Forest berries & $7 / 63$ & 0.52 & $0.27-1.02$ & 0.06 & $7 / 60$ & 0.53 & $0.26-1.07$ & 0.07 \\
\hline $\begin{array}{l}\text { Salmon, salmon } \\
\text { trout, whitefish }\end{array}$ & $8 / 19$ & 1.42 & $2.02-4.62$ & 0.002 & $7 / 18$ & 2.35 & $1.23-4.45$ & 0.009 \\
\hline $\begin{array}{l}{ }^{a} \text { Adjusted for age a } \\
{ }^{b} \text { Adjusted for age, } \\
\text { yrs. } \\
{ }^{c} \text { Adjusted for age. }\end{array}$ & $\begin{array}{l}\text { gender. } \\
\text { nder, smoking, o }\end{array}$ & sity, far & ily history o & cancer an & residence in glass & Jorks a & before the & ge of 5 \\
\hline
\end{tabular}

\subsection{Identified factors of relevance to exposure and dose interpretations (Papers I- III)}

As expected, well-known exposure sources such as smoking (Table 4, Paper II), age, metal and glassworkers (EFSA 2013; Järup and Åkesson 2009; WHO 2016), (Papers II and III), but also residence time (Paper III) in the contaminated areas contributed to the total body burden of $\mathrm{Cd}$ and $\mathrm{Pb}$ (Figure 9, Figure 10). In particular, current smokers and those who work as a glass blower or glass grinder were associated with increased $\mathrm{Cd}$ and $\mathrm{Pb}$ exposure (Table 5). Also, being active smokers, glass grinders or other metal workers were associated with increased 1-OHPy in urine (Table 4, Paper III). 
All the well-known risk factors for cancer, such as smoking, age, obesity and family history of cancer (NIH, 2018), but also residence in a glassworks area during the first five years of life, were identified as risk factors for total cancer in Paper III (Table 2a, Paper III). Working in metal production was identified as a risk factor for female breast cancer in Paper I (Table 3, Paper I). Age, residence in Gusum during the first five years of life and metal working were identified as risk factors for total cancer in Paper II, while smoking was identified as a non-significant risk factor for female total cancer only.

Table 5. Mean concentrations (SD) of $C d, P b$ and As in blood $(\mu \mathrm{g} / L)$ in smokers, non-smokers, glass/metalworkers and non-glass/metalworkers, stratified into cases and controls. Restriction criteria of at least 5 years of residence time in the contaminated glasswork area and a latency time of at least 10 years between first residence year and time of diagnosis (cases) or inclusion in the study (controls) were applied. The $p$-values are adjusted for age, gender, and glass/metalworking for the smoking variable and for age, gender and smoking for the glass/metalworking variable. Significant $p$ values are visualized in bold.

\begin{tabular}{|c|c|c|c|c|c|c|c|}
\hline \multicolumn{8}{|l|}{ Cases } \\
\hline & & B-Cd & p-value & $\mathrm{B}-\mathrm{Pb}$ & p-value & B-As & p-value \\
\hline & & Mean (SD) & & Mean (SD) & & Mean (SD) & \\
\hline \multirow[t]{3}{*}{ Smoking } & Non-smoker $(\mathrm{n}=61)$ & $0.34(0.46)$ & Ref & $16(9.2)$ & Ref & $9.1(4.7)$ & Ref \\
\hline & Former smoker $(n=62)$ & $0.46(0.42)$ & 0.13 & $20(15)$ & 0.28 & $9.2(6.6)$ & 1 \\
\hline & Active smoker $(n=3)$ & $1.7(0.20)$ & $<0.0001$ & 36 (19) & 0.02 & $9.6(2.3)$ & 1 \\
\hline \multirow[t]{5}{*}{ Work } & Non-glass/metal worker $(n=100)$ & $0.43(0.31)$ & Ref & $17(16)$ & Ref & $9.4(6.1)$ & Ref \\
\hline & Glassworker $(n=12)$ & $0.57(0.87)$ & 0.49 & $27(16)$ & 0.03 & $9.5(4.7)$ & 1 \\
\hline & Glass blower $(n=3)$ & $1.4(1.7)$ & $<0.0001$ & 34 (19) & 0.03 & $9.1(2.3)$ & 0.93 \\
\hline & Glass grinder $(n=2)$ & $0.25(0.34)$ & 0.18 & $14(6.9)$ & 0.70 & $5.8(0.01)$ & 0.42 \\
\hline & Other metalworker $(n=14)$ & $0.34(0.15)$ & 0.93 & $18(7.3)$ & 1.00 & $7.4(2.2)$ & 0.68 \\
\hline \multicolumn{8}{|l|}{ Controls } \\
\hline & & B-Cd & p-value & $\mathrm{B}-\mathrm{Pb}$ & p-value & & p-value \\
\hline \multirow[t]{3}{*}{ Smoking } & Non-smoker $(n=247)$ & $0.30(0.20)$ & Ref & $16(9.4)$ & Ref & $7.7(4.3)$ & Ref \\
\hline & Former smoker $(n=209)$ & $0.43(0.30)$ & $<0.0001$ & $18(11)$ & 0.06 & $8.5(5.5)$ & 0.29 \\
\hline & Active smoker $(n=19)$ & $1.4(0.77)$ & $<0.0001$ & $24(16)$ & 0.002 & $10(7.2)$ & 0.05 \\
\hline \multirow[t]{5}{*}{ Work } & Non-glass/metal worker $(n=355)$ & $0.39(0.38)$ & Ref & $16(9.1)$ & Ref & $8.2(5.2)$ & Ref \\
\hline & Glassworker $(n=48)$ & $0.58(0.63)$ & $<0.0001$ & $24(16)$ & $<0.0001$ & $7.9(4.6)$ & 1 \\
\hline & Glass blower $(n=7)$ & $0.54(0.56)$ & 0.26 & $40(17)$ & $<0.0001$ & $8.8(4.0)$ & 0.78 \\
\hline & Glass grinder $(n=11)$ & $0.68(0.72)$ & 0.007 & $28(18)$ & $<0.0001$ & $8.2(3.1)$ & 0.98 \\
\hline & Other metalworker $(n=73)$ & $0.35(0.21)$ & 1 & $18(9.8)$ & 0.10 & $7.9(4.4)$ & 1 \\
\hline
\end{tabular}

\subsection{Association between measured levels of toxic substances in blood/urine and consumption of local food (Papers II and III)}

In the general population, diet is usually the major exposure route for most metals and PCBs. In Gusum, elevated concentrations of metals in vegetables, root crops, berries and mushrooms and PCBs in fish have been previously measured (Helmfrid et al. 2007; Nyberg et al. 2012). In the glassworks area, elevated $\mathrm{Cd}$ and $\mathrm{Pb}$ concentrations in vegetables have been reported (Augustsson et al. 2015; Uddh-Söderberg et al. 2015; Augustsson et al. 2018). It can thus be hypothesized that long-term consumption of local food from the contaminated areas may contribute to elevated body burdens of contaminants. 
Multivariate PCA showed that Cd concentrations in urine were co-variate with consumption of local vegetables (Figure 1, Paper II). Further analyses (main factor ANOVA) confirmed that consumers of local vegetables, berries and mushrooms had higher urinary $\mathrm{Cd}$ concentrations than non-consumers (Table 4, Paper II). When analysing cancer cases and controls separately, a statistically significant association between $\mathrm{Cd}$ concentrations in urine and consumption of local vegetables among cancer cases was found (Table 6).

Table 6. Differences in mean concentrations of $C d$ in urine ( $\mu \mathrm{g} / \mathrm{L}$ adjusted for specific gravity) in cancer cases and controls in relation to long-term consumption of local (Gusum) vegetables, berries and mushrooms (> 6 times/year) and non-consumption (adjusted for age, gender and smoking). Significant differences visualized in bold.

\begin{tabular}{|c|c|c|c|c|c|c|c|c|}
\hline & \multirow[b]{2}{*}{$\begin{array}{l}\text { Consumption } \\
\text { group }\end{array}$} & \multicolumn{3}{|c|}{ Cancer case } & \multicolumn{4}{|l|}{ Controls } \\
\hline & & Mean & SD & p-value & $\begin{array}{l}\text { Consumption } \\
\text { group }\end{array}$ & Mean & SD & p-value \\
\hline \multirow[t]{2}{*}{ Fruit and garden berries } & Non $n=11$ & 0.25 & 0.15 & Ref & Non $n=46$ & 0.29 & 0.12 & Ref \\
\hline & $\begin{array}{l}\text { Consumer } \\
n=20\end{array}$ & 0.44 & 0.27 & 0.02 & $\begin{array}{l}\text { Consumer } \\
n=42\end{array}$ & 0.33 & 0.16 & 0.24 \\
\hline \multirow[t]{2}{*}{ Leafy vegetables } & Non $n=16$ & 0.38 & 0.30 & Ref & Non $n=21$ & 0.29 & 0.12 & Ref \\
\hline & $\begin{array}{l}\text { Consumer } \\
n=16\end{array}$ & 0.37 & 0.20 & 0.83 & $\begin{array}{l}\text { Consumer } \\
n=36\end{array}$ & 0.32 & 0.16 & 0.42 \\
\hline \multirow[t]{2}{*}{ Potatoes } & Non $n=11$ & 0.27 & 0.16 & Ref & Non $n=16$ & 0.28 & 0.11 & Ref \\
\hline & $\begin{array}{l}\text { Consumer } \\
n=19\end{array}$ & 0.44 & 0.28 & 0.04 & $\begin{array}{l}\text { Consumer } \\
n=41\end{array}$ & 0.33 & 0.16 & 0.15 \\
\hline \multirow[t]{2}{*}{ Other root crops } & Non $n=15$ & 0.29 & 0.17 & Ref & Non $n=18$ & 0.29 & 0.11 & Ref \\
\hline & $\begin{array}{l}\text { Consumer } \\
n=19\end{array}$ & 0.44 & 0.28 & 0.04 & $\begin{array}{l}\text { Consumer } \\
n=37\end{array}$ & 0.33 & 0.14 & 0.23 \\
\hline \multirow[t]{2}{*}{ Forest berries } & Non $n=12$ & 0.24 & 0.13 & Ref & Non $n=15$ & 0.29 & 0.12 & Ref \\
\hline & $\begin{array}{l}\text { Consumer } \\
n=18\end{array}$ & 0.48 & 0.28 & 0.005 & $\begin{array}{l}\text { Consumer } \\
n=41\end{array}$ & 0.33 & 0.16 & 0.37 \\
\hline \multirow[t]{2}{*}{ Mushrooms } & Non $n=10$ & 0.22 & 0.12 & Ref & Non $n=19$ & 0.30 & 0.14 & Ref \\
\hline & $\begin{array}{l}\text { Consumer } \\
n=20\end{array}$ & 0.46 & 0.27 & 0.008 & $\begin{array}{l}\text { Consumer } \\
n=39\end{array}$ & 0.33 & 0.15 & 0.37 \\
\hline
\end{tabular}

High, intermediate and non-consumption groups were constructed for locally produced vegetables and fish based on the Gusum study questionnaire data in Paper II. A new PCA analysis was performed with these three consumption groups and all three contaminants $(\mathrm{Cd}$, $\mathrm{Pb}, \mathrm{PCB}$ ) included. Four principal factors were retained based on an eigenvalue $>1$ and scree plot; accounting for $55 \%$ of the variance. Figure 9 shows the first two principal components, which can explain $31 \%$ of the total variance. All consumption of local vegetables was associated with $\mathrm{Cd}$ in urine (Figure 9), while consumption of local fish was associated with $\mathrm{Pb}$ in blood and PCB in plasma. This result is in accordance with Figures 1 and 2 in Paper II.

No significant association was found between PCBs in plasma and reported consumption of local fish, but there was an association with the consumption of herring (non-local fatty sea fish), which is well known to contain elevated concentrations of PCBs (Bignert et al. 2007; Bjermo et al. 2013a; Darnerud et al. 2017). When analysing cancer cases and controls separately, a statistically significant association between consumption of local fish and sumPCBs among cancer cases was found (Table 7). No association was found between $\mathrm{Pb}$ in 
blood and fish consumption (not shown in table). This result could be explained by the fact that cancer cases may be more thoughtful and detailed in reporting long-term food consumption than controls.

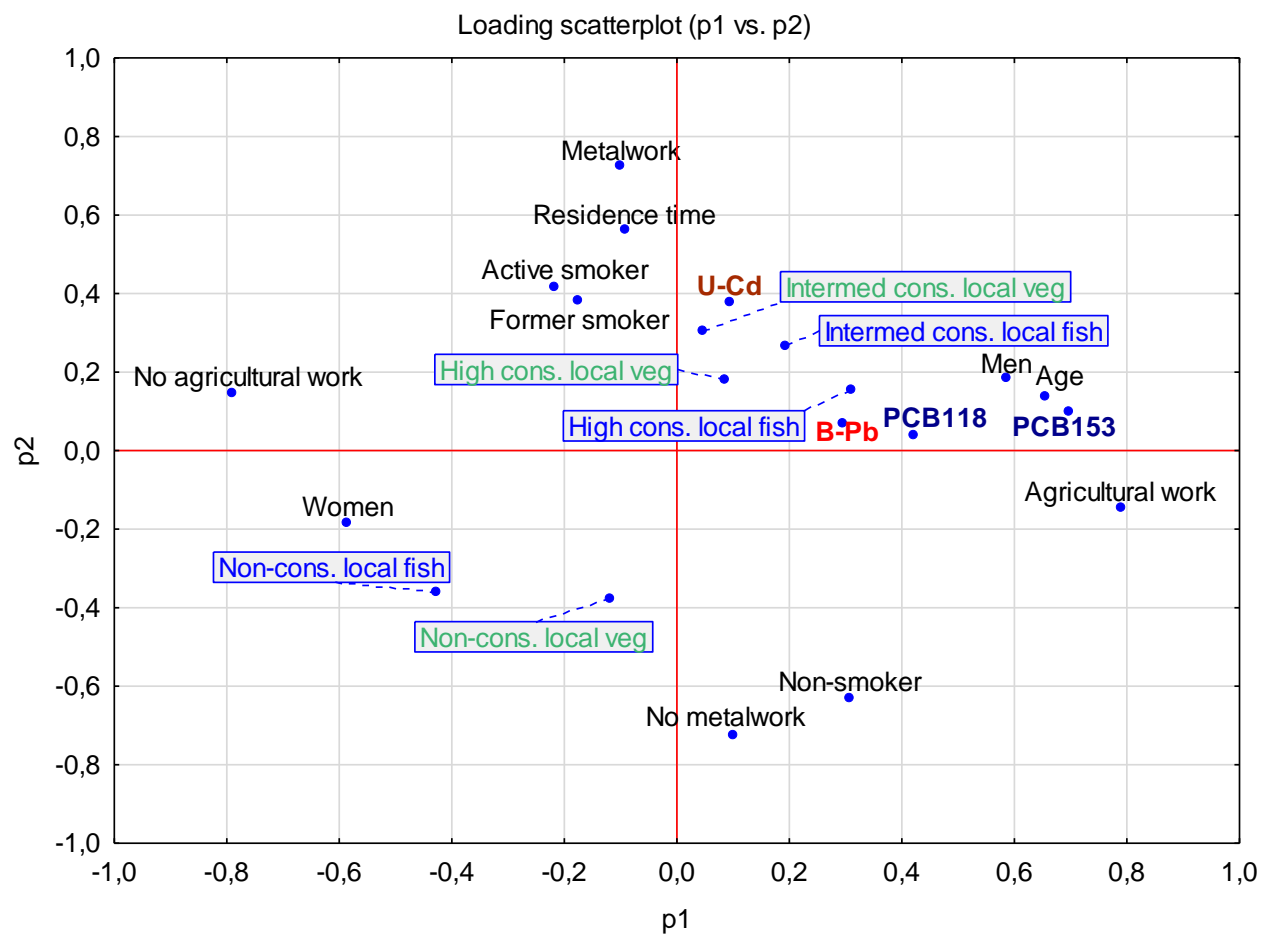

Figure 9. Loading plot displaying the PCA analysis of covariation between concentration of $C d$ (urine), $P b$ (blood), PCB118, PCB153 (plasma) and consumption of local vegetables and fish, age, gender, smoking habit, metal work, agricultural work and residence time in Gusum village. The $x$-and y-axes represent the PC1 (Principal Component 1) and PC2 scores, respectively.

Table 7. Concentrations of $P C B 118, P C B 153$, and sumPCB in plasma (ng/g lipid) in cancer cases and controls in relation to local (Gusum) fish consumption (non-consumption, intermediate (<twice/month) and high consumption ( $\geq$ twice/month). Significant differences, after adjustment for age, gender and herring consumption, are visualized in bold.

\begin{tabular}{lllllllll}
\hline & & \multicolumn{3}{l}{ Cancer case } & & Controls & \\
\hline & Consumption group & Mean & SD & p-value & Consumption group & Mean & SD & p-value \\
\hline PCB118 & Non $\mathrm{n}=14$ & 21.4 & 19.1 & & Non $\mathrm{n}=26$ & 22.2 & 23.0 & \\
& Intermediate $\mathrm{n}=8$ & 25.0 & 16.3 & 1.00 & Intermediate $\mathrm{n}=15$ & 20.4 & 14.8 & 1.00 \\
& High $\mathrm{n}=5$ & 48.9 & 65.2 & 0.27 & High $\mathrm{n}=12$ & 25.7 & 26.7 & 1.00 \\
PCB153 & Non $\mathrm{n}=14$ & 175 & 84.4 & & Non $\mathrm{n}=26$ & 181 & 142 & \\
& Intermediate $\mathrm{n}=8$ & 217 & 60.9 & 0.56 & Intermediate $\mathrm{n}=15$ & 200 & 154 & 1.00 \\
& High $\mathrm{n}=5$ & 262 & 145 & 0.08 & High $\mathrm{n}=12$ & 178 & 92.7 & 1.00 \\
& Non $\mathrm{n}=14$ & 629 & 289 & & Non $\mathrm{n}=26$ & 641 & 480 & \\
& Intermediate $\mathrm{n}=8$ & 805 & 229 & 0.41 & Intermediate $\mathrm{n}=15$ & 674 & 509 & 1.00 \\
& High $\mathrm{n}=5$ & $\mathbf{1 0 1 8}$ & $\mathbf{6 2 6}$ & $\mathbf{0 . 0 3}$ & High $\mathrm{n}=12$ & 635 & 309 & 1.00 \\
\hline
\end{tabular}


In Paper III, high consumption of all three food groups was associated with higher metal concentrations in the blood (Figure 10). Further analyses (main factor ANOVA) of associations between local food intake and metal concentrations in the blood and urine confirmed that high consumers of certain local foods had moderately higher $\mathrm{Cd}$, and lower $\mathrm{Pb}$, concentrations in their blood (Table 8). No such trend was observed for As in blood or urine. It should be pointed out that we did not specify As in organic or inorganic forms; therefore, the concentrations represent both inorganic and organic As species.

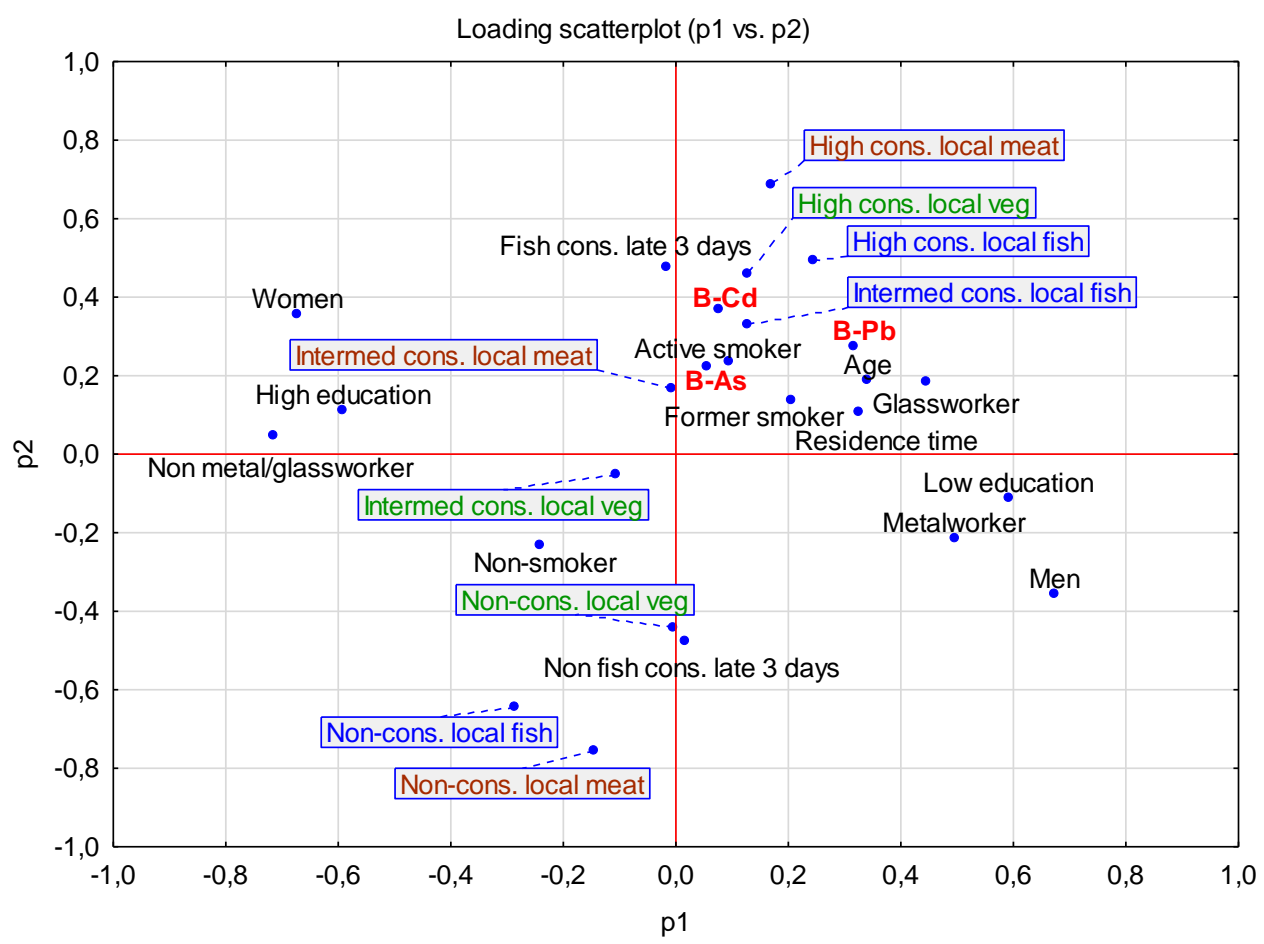

Figure 10. Loading plot displaying the PCA analysis of co-variation between $\mathrm{As}, \mathrm{Pb}$ and $\mathrm{Cd}$ concentrations in blood $(\mu \mathrm{g} / L)(n=658)$ and the variables age, gender, smoking habit (active, former, non-smoker), working at a glassworks or with metalwork, residence time in a glassworks area, fish consumption during the preceding three days and consumption of local vegetables, meat and fish. The $x$ - and $y$-axes represent the PC1 and PC2 scores, respectively. 
Table 8. Mean concentrations of $\mathrm{Cd}, \mathrm{Pb}$ and As in blood ( $\mu \mathrm{g} / \mathrm{L}$ ) in different consumption groups (non/low, intermediate and high) of locally produced food. The $p$-values are adjusted for age, glass/metalwork and smoking $(\mathrm{Cd}, \mathrm{Pb})$ and for age, gender and fish intake during the three days immediately before donation of blood and urine (As).

\begin{tabular}{|c|c|c|c|c|c|c|c|}
\hline & Consumption group & $\begin{array}{l}\text { B-Cd } \\
\text { mean (SD) }\end{array}$ & p-value & $\begin{array}{l}\text { B-Pb } \\
\text { mean (SD) }\end{array}$ & p-value & $\begin{array}{l}\text { B-As } \\
\text { mean (SD) }\end{array}$ & p-value \\
\hline \multirow[t]{3}{*}{ Potatoes } & Non/low $n=142$ & $0.37(0.37)$ & Ref & $17(11)$ & Ref & $8.8(6.1)$ & Ref \\
\hline & Intermediate $\mathrm{n}=190$ & $0.36(0.33)$ & 1 & $17(11)$ & 1 & $7.8(4.1)$ & 0.30 \\
\hline & High $n=128$ & $0.45(0.43)$ & 0.07 & $19(13)$ & 0.71 & $7.8(4.3)$ & 0.22 \\
\hline \multirow[t]{3}{*}{ Other root crops } & Non/low $n=149$ & $0.36(0.33)$ & Ref & $17(9.8)$ & Ref & $8.2(4.5)$ & Ref \\
\hline & Intermediate $\mathrm{n}=218$ & $0.39(0.37)$ & 1 & $17(12)$ & 1 & $8.2(4.7)$ & 1 \\
\hline & High $n=74$ & $0.47(0.48)$ & 0.02 & $19(13)$ & 0.63 & $7.9(4.2)$ & 1 \\
\hline \multirow[t]{3}{*}{ Leafy vegetables } & Non/low $n=176$ & $0.36(0.32)$ & Ref & $17(10)$ & Ref & $8.5(4.7)$ & Ref \\
\hline & Intermediate $\mathrm{n}=211$ & $0.41(0.38)$ & 0.34 & $17(12)$ & 1 & $8.0(4.7)$ & 0.88 \\
\hline & High $n=53$ & $0.48(0.53)$ & 0.02 & $18(14)$ & 1 & $7.9(3.8)$ & 1 \\
\hline \multirow[t]{3}{*}{ Other vegetables } & Non/low $n=157$ & $0.35(0.30)$ & Ref & $16(9.8)$ & Ref & $8.8(5.7)$ & Ref \\
\hline & Intermediate $\mathrm{n}=194$ & $0.40(0.41)$ & 0.24 & $17(12)$ & 1 & $8.3(4.9)$ & 0.97 \\
\hline & High $n=75$ & $0.48(0.46)$ & 0.003 & $19(13)$ & 0.23 & $7.3(3.2)$ & 0.08 \\
\hline \multirow[t]{3}{*}{ Mushrooms } & Non/low $n=155$ & $0.38(0.36)$ & Ref & $16(9.9)$ & Ref & $8.1(4.3)$ & Ref \\
\hline & Intermediate $\mathrm{n}=313$ & $0.40(0.39)$ & 1 & $17(11)$ & 0.47 & $8.4(4.9)$ & 1 \\
\hline & High $n=24$ & $0.46(0.39)$ & 0.66 & $21(14)$ & 0.06 & $8.6(4.2)$ & 1 \\
\hline \multirow[t]{3}{*}{ Chicken } & Non/low $n=310$ & $0.37(0.33)$ & Ref & $17(11)$ & Ref & $8.2(4.9)$ & Ref \\
\hline & Intermediate $n=36$ & $0.41(0.48)$ & 1 & $16(7.6)$ & 1 & $7.6(2.9)$ & 1 \\
\hline & High $n=60$ & $0.47(0.53)$ & 0.04 & $20(12)$ & 0.06 & $8.5(4.2)$ & 1 \\
\hline \multirow[t]{3}{*}{ Lamb } & Non/low $n=355$ & $0.37(0.34)$ & Ref & $16(11)$ & Ref & $8.2(4.5)$ & Ref \\
\hline & Intermediate $\mathrm{n}=39$ & $0.36(0.23)$ & 0.36 & $19(12)$ & 0.55 & $7.8(2.8)$ & 1 \\
\hline & High $n=21$ & $0.71(0.84)$ & $<0.001$ & $21(14)$ & 0.10 & $7.9(4.3)$ & 1 \\
\hline \multirow[t]{3}{*}{ Game meat } & Non/low $n=216$ & $0.37(0.30)$ & Ref & $16(10)$ & Ref & $8.3(5.0)$ & Ref \\
\hline & Intermediate $\mathrm{n}=115$ & $0.40(0.43)$ & 1 & $16(12)$ & 1 & $7.8(3.9)$ & 0.99 \\
\hline & High $n=117$ & $0.40(0.42)$ & 1 & $19(11)$ & 0.06 & $8.3(4.3)$ & 1 \\
\hline \multirow{3}{*}{$\begin{array}{l}\text { Perch, pike, pike- } \\
\text { perch, burbot }\end{array}$} & Non/low $n=306$ & $0.38(0.34)$ & Ref & $16(10)$ & Ref & $8.0(4.7)$ & Ref \\
\hline & Intermediate $\mathrm{n}=115$ & $0.36(0.27)$ & 1 & $18(11)$ & 0.59 & $8.9(4.9)$ & 0.18 \\
\hline & High $n=34$ & $0.48(0.49)$ & 0.05 & $22(15)$ & 0.003 & $8.0(3.2)$ & 1 \\
\hline \multirow{3}{*}{$\begin{array}{l}\text { Salmon, salmon } \\
\text { trout, whitefish }\end{array}$} & Non/low $n=357$ & $0.38(0.35)$ & Ref & $17(10)$ & Ref & $8.3(4.9)$ & Ref \\
\hline & Intermediate $\mathrm{n}=35$ & $0.35(0.26)$ & 1 & $17(12)$ & 1 & $7.7(3.4)$ & 1 \\
\hline & High $n=18$ & $0.45(0.41)$ & 0.72 & $18(15)$ & 1 & $7.5(2.9)$ & 1 \\
\hline
\end{tabular}

High consumption of vegetables and active smoking were associated with 1-OHPy in urine (Figure 2 and Table 5, Paper III). When PCBs and the covariate consumption of herring were included in the PCA analysis, the association between 1-OHPy and high consumption of local vegetables was weaker, due to the strong associations with the other high consumer variables (Figure 11). Three principal factors were retained based on eigenvalues $>1$ and a scree plot, accounting for $35 \%$ of the total variance. Figure 11 shows the first two principal components, which can explain about $24 \%$ of the total variance. 


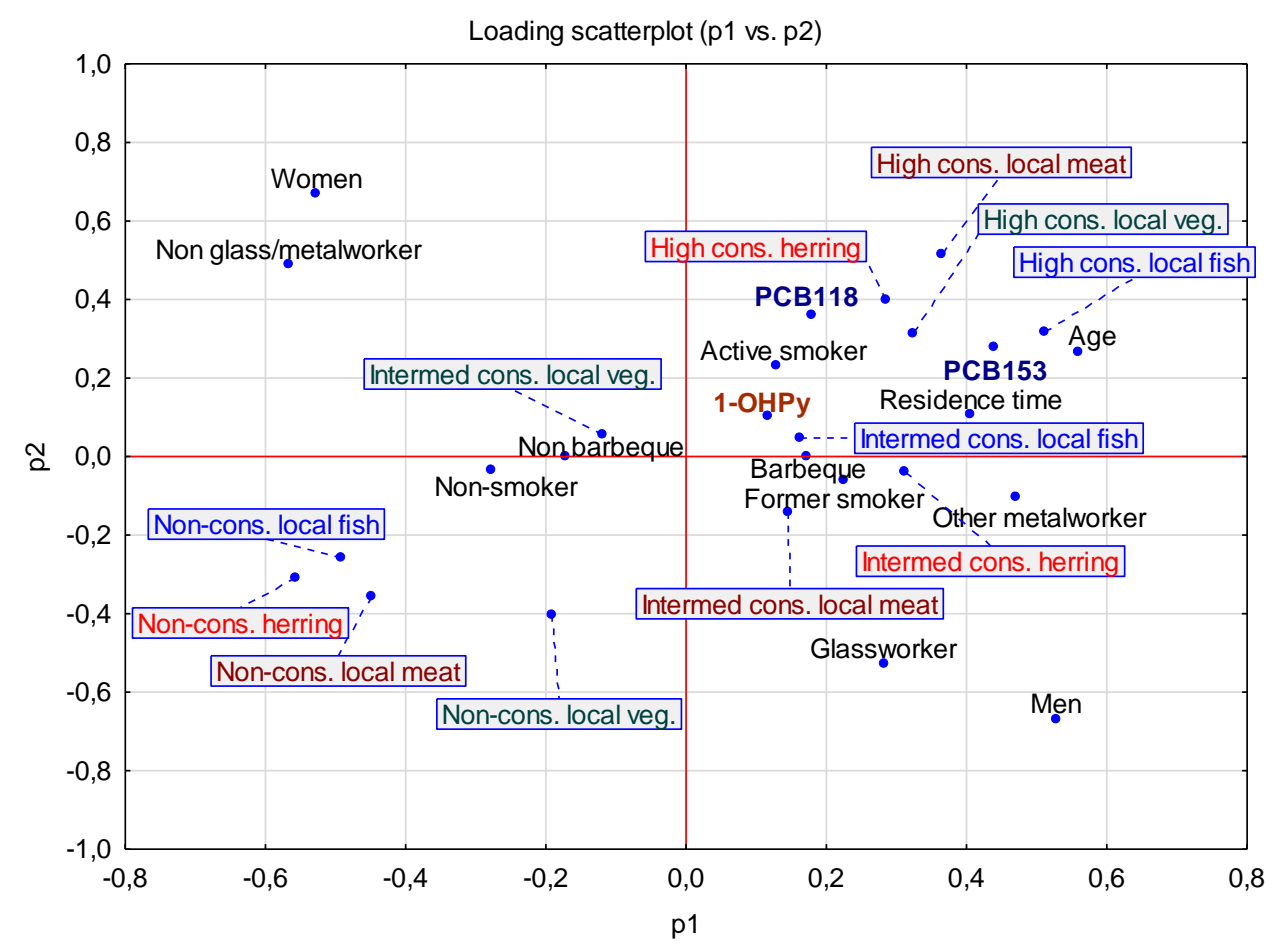

Figure 11. Loading plot displaying the PCA analysis of co-variation between 1-OHPY concentrations in urine ( $\mathrm{ng} / \mathrm{g}$ crea), PCB118 and PCB153 in plasma $(\mu \mathrm{g} / \mathrm{L})(\mathrm{n}=400)$ and the variables age, gender, smoking habit (active, former, non-smoker), working at a glassworks or with other metalwork, residence time in a glassworks area, consumption of herring and barbeque and consumption of local vegetables, meat and fish. The $x$ - and $y$-axes represent the PC1 and PC2 scores, respectively.

It can be concluded that reported high consumption of certain local vegetables from contaminated areas could be associated with the Cd concentration measured in the study populations (Papers II and III). A significantly elevated trend of $\mathrm{Cd}$ and $\mathrm{Pb}$ in the blood of high consumers of locally caught fish in glassworks areas (Paper III) was observed, but not in the Gusum area (Paper II). Finally, reported high consumptions of local chicken, game meat and fish were associated with increased levels of $\mathrm{Cd}$ in the blood (Paper III). These results may indicate an influence from the contaminated areas. The associations may reflect a higher exposure in the past, partly due to the inhalation of dust and volatile compounds that were released into the air prior to the installation of technical solutions for flue-gas purification. The historic emissions to the air were extensive in both study areas and have contributed to the diffuse contamination of the soil and deposits on vegetables, berries and mushrooms, primarily in areas close to these industries. However, it has to be pointed out that reported high consumption of non-local food, from places other than the study areas in Papers II and III, were not associated with increased concentrations of metals in blood/urine, 
except for increased $\mathrm{Cd}$ concentrations in the blood among consumers of non-local game meat (Paper III) and increased concentrations of PCBs in consumers of herring (Paper II).

\subsection{How well does the questionnaire data reflect measured levels in human biological samples? (Papers II and III)}

In Papers II and III, the variables in the questionnaire describe differences in metal exposure in the study populations reasonably well. Reported high intake of certain local foods was associated with increasing metal concentrations in the blood and/or urine (Papers II and III). Furthermore, well-known exposure sources, such as reported smoking, being a glass and/or metalworker and age (EFSA 2013; Järup \& Åkesson 2009; WHO 2016), but also residence time contributed to the total body burden of contaminants. Several studies have also confirmed that self-reported FFQ describe differences in biomarker concentrations reasonably well (Björnberg et al. 2005; Brantsaeter et al. 2007; Bergqvist et al. 2012; Smolders et al. 2014; Haines et al. 2017; Kowalska et al. 2018). These findings suggest that the FFQ and biomarkers can be useful tools for estimation of exposure.

\subsection{Identified health effects in populations living in contaminated areas (Papers I- III)}

The established risk factors for cancer such as age, smoking, obesity and cancer in close relatives have been identified in Paper III. There are also significantly increased risks of rectum cancer and cancer of the kidney, bladder and other urinary organs among glassworkers, with male glass blowers having the highest risk. Residing in a glassworks area during the first five years of life was significantly associated with increased risk of total cancer in both genders as one group and in women. High consumption of local fish was the strongest determinant for total cancer in the both-genders group, and for male genital cancer (prostate). Significant associations between digestive cancer (rectum cancer) and high consumption of local game meat, chicken, lamb and fish were also found. High consumption of local fish was also shown to be the strongest determinant for total cancer among females in Paper I, while residing in the contaminated area (Gusum village) during the first five years of life was significantly associated with increased risk of total cancer among males. Reported high consumption of non-local food was not associated with increased risk of total cancer (Papers II and III) or for specific forms of cancer (Paper III).

In spite of these results, there were no significant differences in concentrations of metals or PCBs between cancer cases and controls (Papers II and III). The associations between consumption of local food and different types of cancer may reflect higher exposure in the past. If the consumption of local food contributes to the risk of acquiring cancer, that contribution is probably lower today than previously. Furthermore, it cannot be ruled out that other contaminants in food contribute to the increased cancer risks observed.

Other types of health effects that may be associated with high metal exposure were not investigated in Papers I-III. Common public health diseases such as osteoporosis, kidney 
disease, cardiovascular disease and diabetes have previously been associated with metal and persistent organochlorine pollutants (POP) exposure (Rylander et al. 2005; Taylor et al. 2013; Åkesson et al. 2014; ATSDR 2007; Bergqvist et al. 2014; Bergqvist et al. 2016; Barregård et al. 2016; Kippler et al. 2016; Larsson \& Wolk 2016; Nordberg \& Nordberg 2016). Due to this and my own curiosity, two PCA analyses of the study populations were performed, as a first step into a further study of the associations between exposure to contaminants and other health effects (Preliminary data, Figures 12-14). Figure 12 shows that concentrations of Cd and $\mathrm{Pb}$ in the blood and urine co-variates with smoking, consumption of local vegetables and fish and cancer-free controls. A weaker association was found between the concentrations of metals in blood and urine and the self-reported diseases of osteoporosis, high blood pressure and cardiovascular disease. PCB concentrations in plasma were associated with age, male gender and self-reported diabetes (Figure 12), which is in agreement with earlier studies (Taylor et al. 2013).

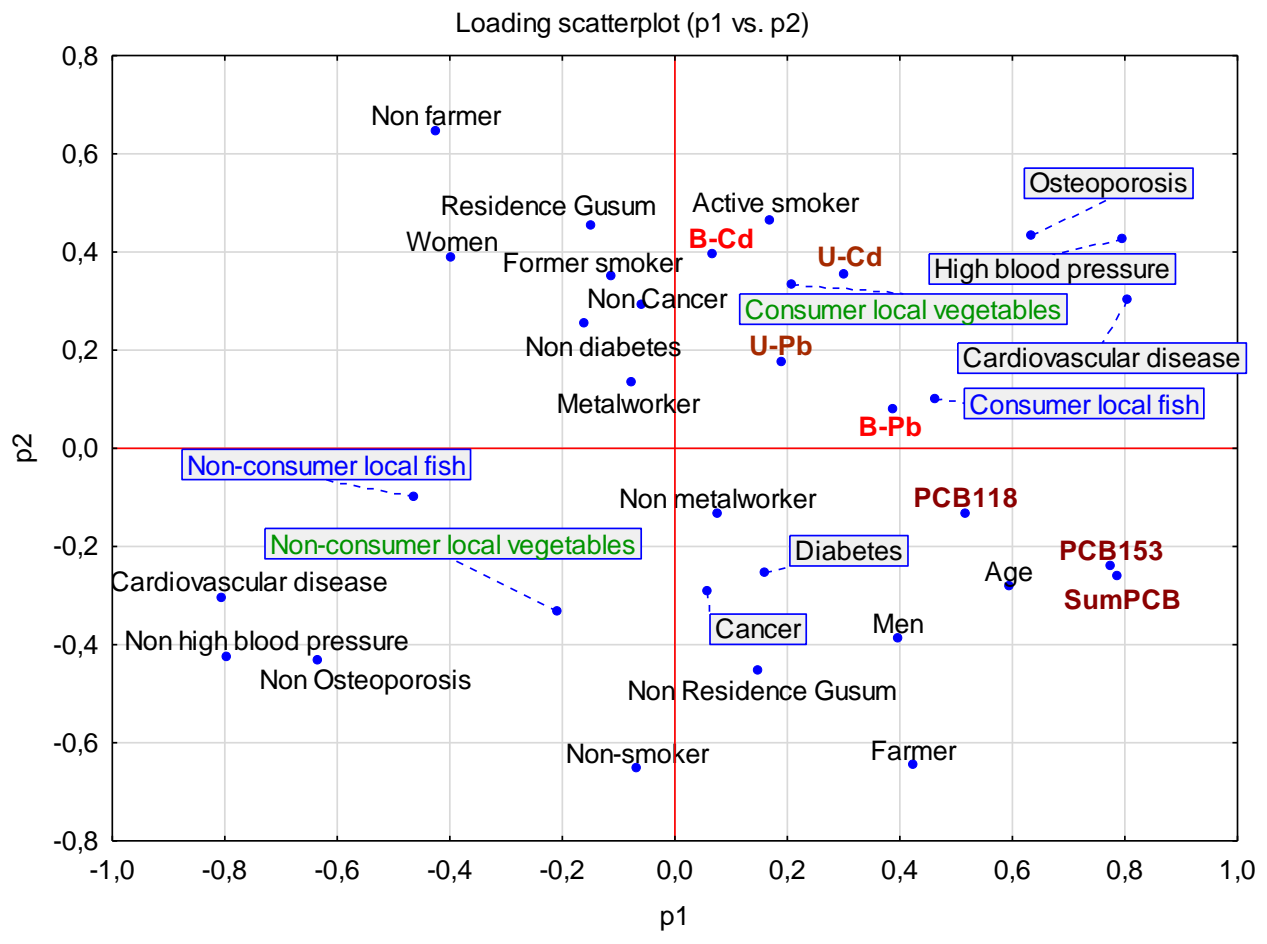

Figure 12. Preliminary data, loading plot displaying the PCA analysis of co-variation between $P b$ and $C d$ concentrations in blood $(\mu \mathrm{g} / L)$ and urine $(\mu \mathrm{g} / \mathrm{L}$, adjusted for specific gravity) and concentration of PCBs in plasma (ng/g lipid) and the variables cancer and self-reported disease (osteoporosis, iron deficiency, kidney disease, diabetes, high blood pressure and cardiovascular disease), age, gender, smoking habit (active, former, non-smoker), metalworker, farmer, residence in Gusum village, consumption of local vegetables and fish. The $x$-and y-axes represent the PC1 and PC2 scores, respectively. 
Preliminary data from the glassworks study (in cancer-free controls, only) showed that concentrations of $\mathrm{Cd}$ in blood and urine co-variates with self-reported osteoporosis and wellknown risk factors such iron deficiency and smoking (Figure 13), which is also confirmed in previous studies (Berglund et al. 1994; Berglund et al. 2011; Järup \& Åkesson 2009).

Furthermore, $\mathrm{Cd}$ in blood and urine co-variates with self-reported diabetes, stroke, high blood pressure, and heart disease as well as well-known risk factors such as smoking, age and obesity (Figure 14), which is also confirmed by others (Barregård et al. 2016; Larsson \& Wolk 2016). These preliminary results will be further investigated.

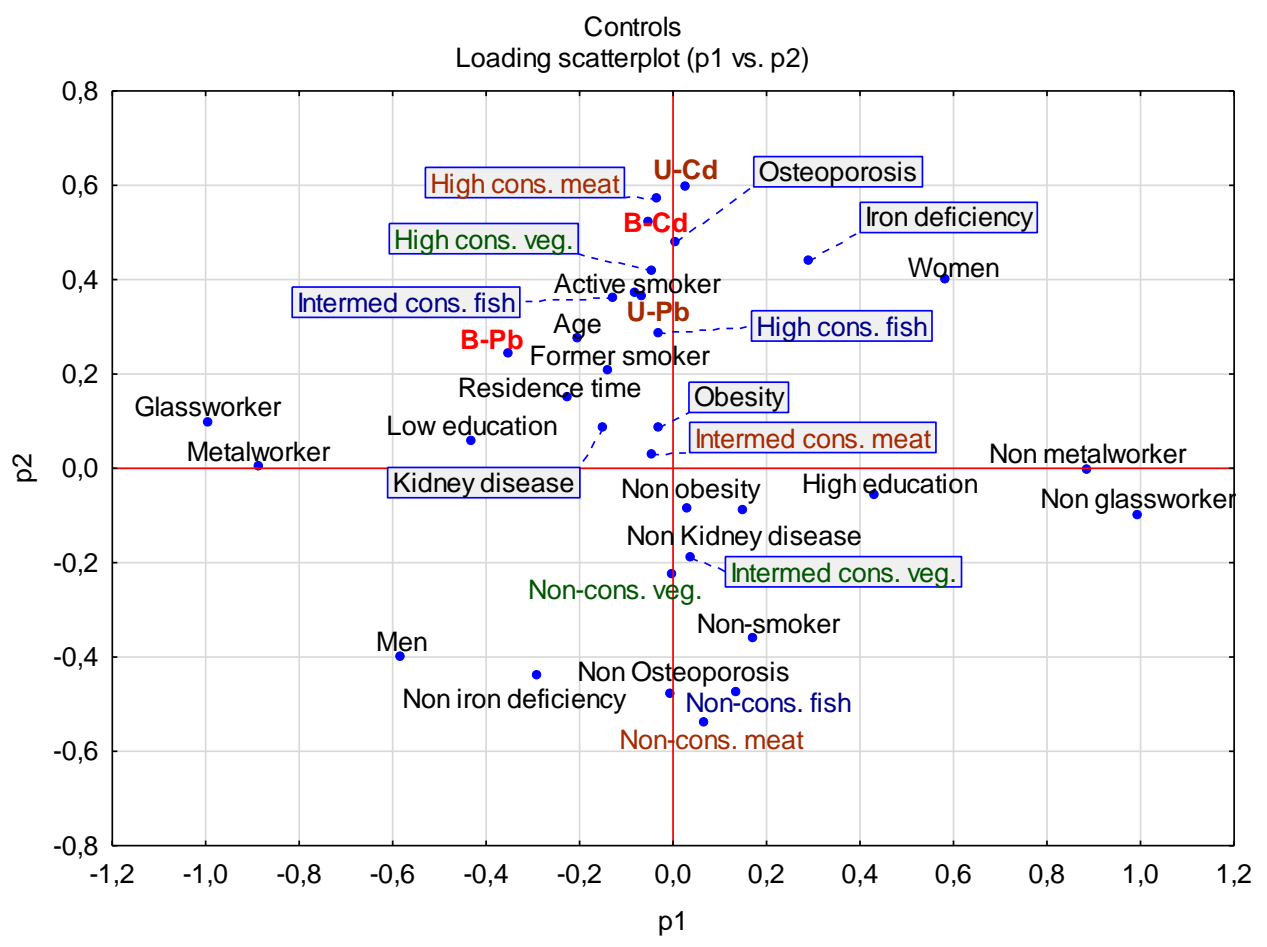

Figure 13. Preliminary data in cancer-free controls, only. Loading plot displaying the PCA analysis of co-variation between Pb and Cd concentrations in blood $(\mu \mathrm{g} / \mathrm{L})$ and urine $(\mu \mathrm{g} / \mathrm{g}, \mathrm{crea})$ and the variables self-reported disease (osteoporosis, iron deficiency and kidney disease), age, gender, smoking habit (active, former, non-smoker), obesity, glassworker, metalworker, residence time in a glassworks area, consumption of local vegetables, meat and fish. The $x$-and $y$-axes represent the PC1 and PC2 scores, respectively. 
Controls

Loading scatterplot (p1 vs. p2)

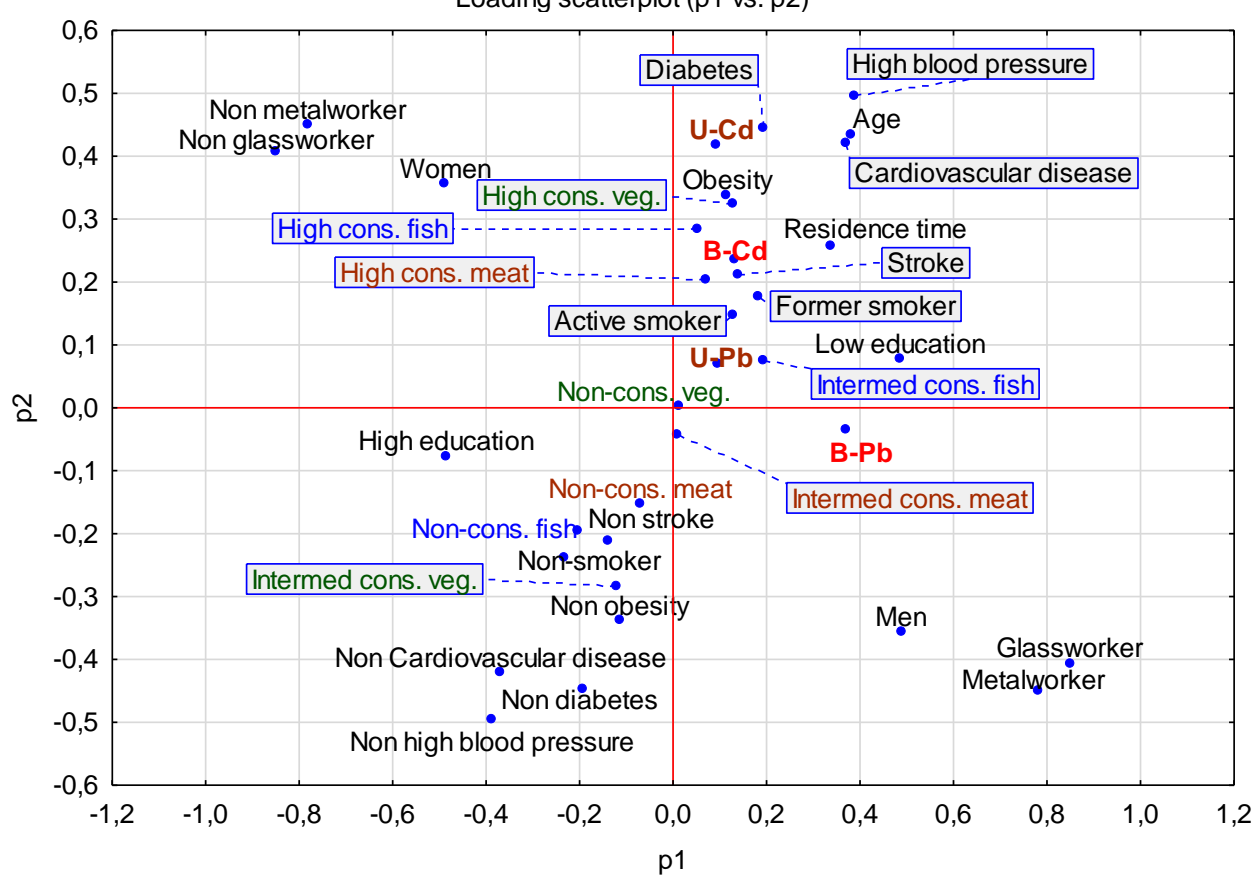

Figure 14. Preliminary data in cancer-free controls, only. Loading plot displaying the PCA analysis of co-variation between $\mathrm{Pb}$ and $\mathrm{Cd}$ concentrations in blood $(\mu \mathrm{g} / \mathrm{L})$ and urine $(\mu \mathrm{g} / \mathrm{g}, \mathrm{crea})$ and the variables self-reported disease (diabetes, high blood pressure and cardiovascular disease), age, gender, smoking habit (active, former, non-smoker), obesity, glassworker, metalworker, residence time in a glassworks area, consumption of local vegetables, meat and fish. The $x$-and $y$-axes represent the $P C 1$ and $P C 2$ scores, respectively.

\subsection{Are populations residing in contaminated areas more exposed than others? (Papers II and III)}

Measured concentrations of contaminants in the blood varied substantially among participants in both studies (Papers II and III). Regarding comparisons with other studies of general populations, it has been shown that there is a risk that interpretation could be hampered by differences in the study design, age, gender, socioeconomics, lifestyles and dietary habits, among other factors. Also, the analytical methods may differ among studies and the sensitivity of analytical methods may differ between labs. This fact makes it difficult to exactly compare concentrations of biomarkers with other studies. However, despite historically high environmental concentrations of metals (Papers II and III) and PCBs (Paper II), the overall current body burdens of measured contaminants were similar or moderately higher in populations residing in contaminated areas compared to other subpopulations in the same age-range (Tables 9 and 10). This indicates that, on average, the contaminant exposure today is not higher among the general population residing in the study 
areas than in other, non-contaminated areas, but the exposure was possibly higher in the past. Nevertheless, high consumers of locally produced food are more exposed than nonconsumers. To be a smoker in combination with working at a glassworks or in a metal industry increases the exposure to metals. In addition, high consumption of contaminated fish, with high lipid content, such as salmon or herring, contributes to increased exposure to PCBs and other persistent organochlorines.

Table 9. Measured concentration of $\mathrm{Cd}$ and $\mathrm{Pb}$ in blood $(\mu \mathrm{g} / \mathrm{L})$ compared to populations in the contaminated areas, Gusum and glassworks area, and compared to other population groups in noncontaminated areas in Sweden.

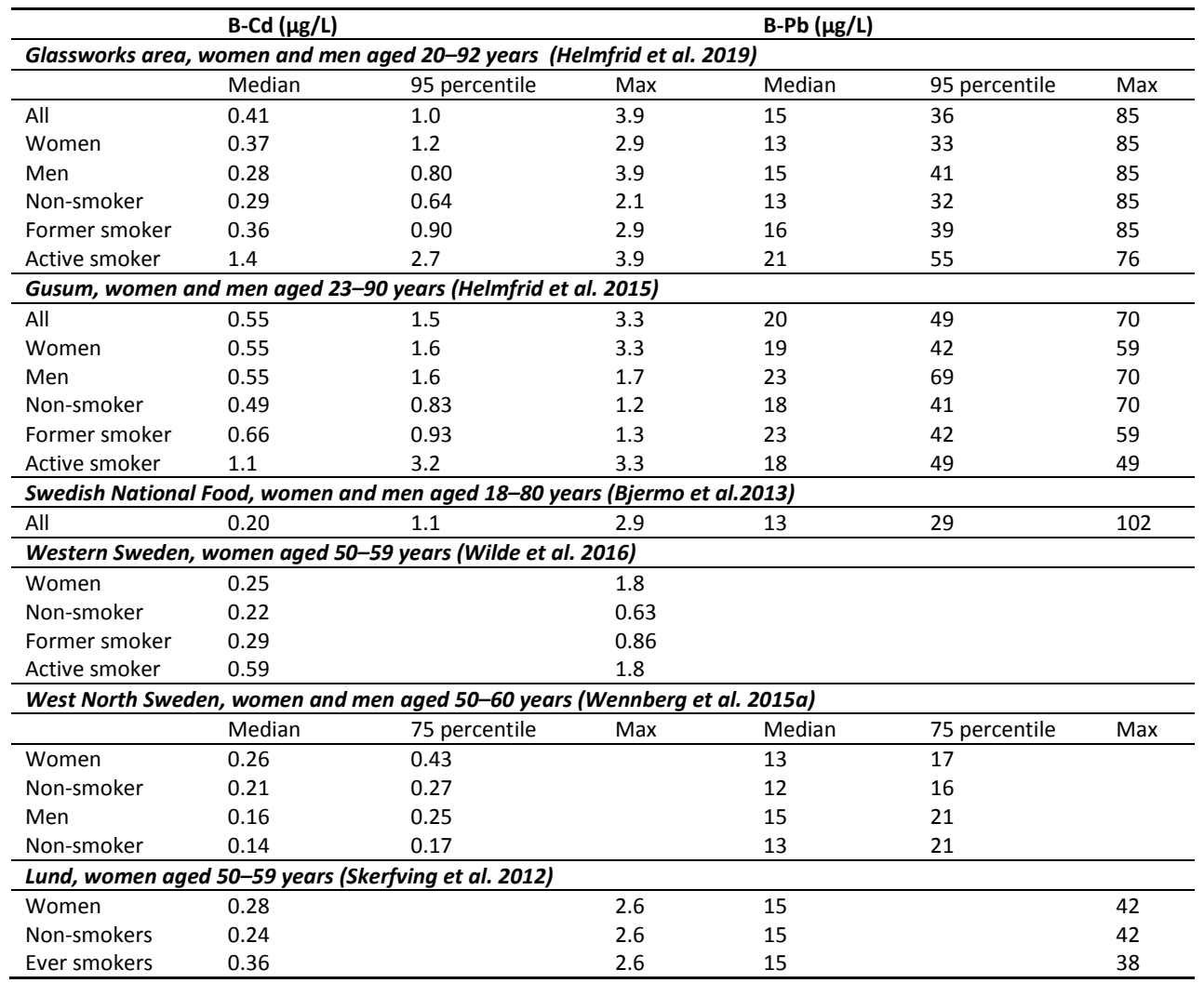


Table 10. Measured concentration of PCBs in plasma ( $\mathrm{ng} / \mathrm{g}$ lipid and $\mathrm{pg} / \mathrm{mL}$ ) compared to populations in the contaminated area, Gusum, and compared to other population groups in non-contaminated areas in Sweden.

\begin{tabular}{|c|c|c|c|c|}
\hline \multicolumn{5}{|c|}{ Gusum, women and men aged 23-90 years (Helmfrid et al. 2015) } \\
\hline & PCB118 (ng/g lipid) & & PCB153 (ng/g lipid) & \\
\hline & Median & Max & Median & Max \\
\hline Women & 18 & 165 & 166 & 577 \\
\hline Men & 18 & 68 & 206 & 653 \\
\hline \multicolumn{5}{|c|}{ PIVUS, women and men aged 70 years (Salihovic et al. 2012) } \\
\hline Women & 35 & & 219 & \\
\hline Men & 29 & & 248 & \\
\hline \multicolumn{5}{|c|}{ Fish consumers, Lake Vättern, women, aged 37-87 years (Helmfrid et al. 2003) } \\
\hline & PCB118 (ng/g lipid) & & PCB153 (ng/g lipid) & \\
\hline Women & & & 312 & 914 \\
\hline \multicolumn{5}{|c|}{ Women aged $50-74$ years (Glynn et al. 2000) } \\
\hline & PCB118 (ng/g lipid) & & PCB153 (ng/g lipid) & \\
\hline Women & 43 & 178 & 223 & 607 \\
\hline \multicolumn{5}{|c|}{ Gusum, women and men aged 23-90 years (Helmfrid et al. 2015) } \\
\hline & PCB118 $(\mathrm{pg} / \mathrm{mL})$ & & PCB153 (pg/mL) & \\
\hline & Median & Max & Median & Max \\
\hline Women and men & 119 & 993 & 1147 & 3170 \\
\hline \multicolumn{5}{|c|}{ Swedish National Food, women and men aged 18-80 years (Bjermo et al. 2013a) } \\
\hline & PCB118 (pg/mL) & & PCB153 (pg/mL) & \\
\hline Women and men & 37 & 974 & 449 & 2789 \\
\hline \multicolumn{5}{|c|}{ West North Sweden, women and men aged 30-60 years (Wennberg et al. 2012) } \\
\hline & PCB118 (pg/mL) & & PCB153 (pg/mL) & \\
\hline Women & 115 & 1561 & 937 & 3745 \\
\hline Men & 101 & 748 & 1075 & 7993 \\
\hline
\end{tabular}

\subsection{Methodological considerations}

\subsubsection{Study design}

Paper I is based on two epidemiological sub-studies: 1) a register-based study, followed by 2) a questionnaire-based case-control study. Papers II and III are based on reported long-term consumption data available from a questionnaire in combination with the biological monitoring of individuals selected from two different case-control studies of the populations (Gusum and the Glassworks area, respectively).

In Sweden, the national cancer register is one of the country's oldest registers and contains individual data of good quality dating back to 1979, which allows the study of cancer outcomes in a specific area. The register and case-control study design is useful as a first step when searching for diseases in a population living in a historically contaminated area. It then explores the possible relations between a variety of exposures and a certain disease. A disadvantage with case-control studies is that they are retrospective and rely on varying data quality because they depend on the participants' memories and, in addition, people with a disease will be more motivated to recall risk factors (Gordis 2008). We used a detailed and comprehensive questionnaire containing questions on self-reported lifetime residences and occupations, as well as current and past consumption habits during the past 30 years. There is 
a risk of misclassification of exposure since it is difficult to remember amounts and types of food consumed that far back in time. Generally, the responders knew whether they had consumed local food or not and could reasonably well assess approximate frequencies over time. Reported consumption a long way back in time and current consumption of local food were often similar (Papers I-III), which can be interpreted as meaning that their eating habits had not changed over time or that they report the same for past consumption as for recent intake of food.

Another source of error is underestimation. In the present studies, many responders (primarily controls) seemed to skip answering if they were non-consumers of local food. This was confirmed by an assistant involved in Paper I, who contacted participants who missed answers and then supplemented the answer before the data analysis was performed. In Paper III, it was confirmed by the nurse who asked the study participants when they donated blood and urine. These data were supplemented in association with the sampling of blood and urine. In Paper III, we did not call the other responders who only participated in the questionnaire study, due to lack of resources.

In order to measure exposure (internal dose/body burden), we used the biomarkers of contaminants in blood/urine and hair. Biomarkers reflect the exposure or the internal dose/body burden and whether and to what extent metals or other contaminants are really taken up (absorbed) by the body from the environment via oral, inhalation and/or dermal routes (Angerer et al. 2007). This information is important and cannot be captured by environmental measurements of soil, vegetables, fruit, berries, mushrooms, fish, meat, water, air, dust etc. Another advantage of biomarkers is consequently that we are able to measure levels of possible contaminants in the body and link them to the various exposure variables identified in the questionnaire and to a specific disease. Combining biomarker and questionnaire information is necessary in this type of study, because biomarker concentrations vary both between and within individuals and over time due to various factors. Information on the factors of age, gender, BMI, lifestyles (smoking, food) and occupation can be obtained by means of a questionnaire. A disadvantage of this study design is that the questionnaire and the sampling of blood/urine are performed only at a certain time point and represent a single measurement of the contaminants. On the basis of a single measurement and questionnaire response, it is not possible to conclude whether the exposure has causal health effects. The most optimal study design is to prospectively follow the study participants over time with repeated questionnaires and samplings, but this type of study design is expensive and time consuming.

Quality assurance during both the biological sampling and chemical analysis is important. Prior to the samplings, careful research was carried out on which sampling methods were required for the respective analyses and how the samples should be handled. During the different studies, the methods were evaluated and improved in collaboration with the Swedish National Food Agency. 
Biomarkers can also be used for studies of biochemical and biologicals effects (Angerer et al. 2007). Collected samples of blood and urine in the present thesis have been used to evaluate biological effects in other studies (Ljunggren et al. 2014; Ljunggren et al. 2017) and will be used in further studies.

\subsubsection{Study size}

The first two papers (Papers I and II) were based on a small population in a geographically limited contaminated area, and with a limited number of study participants in the questionnaire and biomonitoring study. In order to achieve better power, the third paper was based on a larger population in a geographically larger contaminated area, and a larger number of participants than in the questionnaire and biomonitoring study. The larger study size makes it possible to adjust for various identified co-variates in the multivariate analyses and to study three consumption groups (non/low, intermediate, high) of local food. In this way, we could determine whether there was an increasing trend of metal body burden in the consumption groups from non/low to intermediate and high.

As expected, there was a low response rate, about $53 \%$ for Paper I and about $30 \%$ for Paper III. In Paper III, a larger number of controls were included to compensate for the expected low response rate. It is well known that the response rate in questionnaire studies tends to decrease, especially if the individuals approached do not feel concerned or motivated to participate (Wenemark et al. 2010). Many of the non-responder participants had lived for only a short time in the study areas (Papers I and III), or stated that they were too old and/or sick to participate.

The broad CIs suggest that the sample size of the case-control study evaluated in Papers II and III were too small to estimate the magnitude of the association in the subgroups of consumption specifically. In order to accomplish a reasonably good power (80\%), the study population in the biomonitoring study (Paper III) should preferably be larger, and missing information in the questionnaire should be less frequent. Regarding response, there was missing data in several of the food frequency questions. About $18 \%$ of the participants in the biomonitoring study did not answer the questions about consumption of local vegetables and about $30 \%$ did not answer the questions about consumption of local animal products. We cannot assume that no answer is equivalent to non-consumption of local food, even if that was possibly the case.

A power calculation was performed before recruiting the study populations for the biomonitoring study (Paper III). Based on Cd mean concentrations in urine among nonconsumers and consumers of vegetables in the Gusum population (Paper II), about 92 consumers and 46 non-consumers were required. Based on this power calculation, the sample size ( $\mathrm{n}=656)$ in Paper III would be sufficient, but the differences in Cd mean concentrations in blood among high consumers, intermediate and non-consumers in the glassworks area were smaller (Paper III, Table 5). A power calculation was also performed at the end of the study. To accomplish $80 \%$ power and detect significant associations between $\mathrm{Cd}$ in blood and the 
consumption groups, about 329 high consumers and 1094 non/seldom/intermediate consumers of local vegetables were required. We had 126 high consumers and 414 non/seldom/intermediate consumers, with a power of $41 \%$. For a corresponding power for $\mathrm{Pb}$ in blood and the consumption of local meat products, 131 high consumers and 319 non/seldom/intermediate consumers were required to accomplish $80 \%$ power. We have 135 high consumers and $329 \mathrm{non} / \mathrm{seldom} /$ intermediate consumers of local meat products, with $81 \%$ power, which indicates an adequate study size, in contrast to the low power in Paper II. In Paper II, there were 70 consumers and 25 non-consumers of vegetables (including mushrooms), with $60 \%$ power based on Cd mean concentrations in urine. Power calculations based on mean concentrations of PCBs among 38 consumers and 40 non-consumers of local fish indicate $18 \%$ power. To accomplish $80 \%$ power and detect significant associations between PCBs in blood and the consumption groups, about 287 consumers and 287 nonconsumers of local fish would have been required.

\subsubsection{Statistical methods}

In the present thesis, both epidemiological and toxicological methodologies have been used. The choice of statistical methods was dependent on the sub-study design and the specific objectives. In Paper I, the relative risks of cancer were evaluated using the Mantel-Haenzel OR while the relative risks of cancer in Paper III were evaluated using logistic regression. The advantage of logistic regression is that both categorical and numerical explanatory variables can be included in the model and the categorical variable can be coded in more than two groups (Petrie \& Sabin 2005). However, the outcome (dependent) variable that was used was binary in both models. Also, nowadays, logistic regression is more common in epidemiological studies.

Odds ratio calculations compare the relative probability of an event occurring between groups (Petrie \& Sabin 2005; Hennekens et al. 1987). In case-control studies, the OR is used as a measure of the strength of the association between an exposure and an outcome, as a measure of the relative risk. The OR represents the odds that an outcome will occur given a particular exposure, compared to the odds of the outcome occurring in the absence of exposure. The magnitude of the OR is affected by the distribution of exposure in each group. In a casecontrol study, the study participants are selected based on the outcome (case or control) rather than on exposure. In our studies (Papers II and III), the aim was to evaluate whether high consumers of local food (exposure) were at greater risk of cancer than controls. In this type of study, the probability of cancer cases being high consumers of local food can be estimated, but the probability of high consumers of local food developing cancer cannot be estimated (Hennekens et al. 1987; Simon 2001; Gordis 2008). In this case, a cohort study design is needed to estimate the relative risk (RR). The relative risk estimates the magnitude of an association between exposure and disease and indicates the probability of developing the disease in the exposed group relative to those who are unexposed (Hennekens et al. 1987; Simon 2001; Petrie \& Sabin 2005; Gordis 2008). 
Large sample sizes are required for multivariate logistic regression in order to obtain sufficient numbers in both categories of response variable. A major issue when building a multivariate logistic regression model is to select which variables should be included (Hennekens et al. 1987; Petrie \& Sabin 2005). If too many variables are included in the model at once, the model may become saturated (full model) and the statistical power may be lower. Significant variables can be dropped, due to a saturated model which is not sensitive enough to detect significant associations. This means that if there is an association between one explanatory variable and the outcome (for example, cancer), the effect may be missed. On the other hand, if as many variables as possible were put into the model at once, a researcher can try to find something significant. One or more variables may be significant, but it can be difficult to interpret the link between several explanatory variables and the outcome (Sperandel 2014). In order to avoid this problem, it is advisable to pre-test all the variables, using models with one explanatory variable at a time, and then include variables with a relevant $p$-value (for example $\mathrm{p} \leq 0.25$ ) in the multivariate model (Hennekens et al. 1987; Sperandel 2014). In order to identify which explanatory variables influence the outcome, all the variables in Paper III were previously identified using Principal Component Analysis (PCA) and further evaluated using univariate and bivariate logistic regression. Then, only significant $(\mathrm{p} \leq 0.20)$ variables were identified as covariates and were included in the multivariate logistic regression.

In Paper I, ORs were presented only for outcomes significantly different from unity or when the risk estimate was above 2 or below 0.5. In Paper III, only associations including at least 5 cases and 18 controls are reported, and when the OR showed a decreasing or increasing trend in the consumption groups, from non/low to intermediate and high consumers of locally produced food.

Principal Component Analysis is a powerful tool for visualization and for detecting patterns in large data sets and is a model in which the factors are based on summarizing the total variance in a dataset (Everett \& Dunn 2001). In Papers II and III, PCA was performed to enable easy visualization and for the purpose of reducing the dimensionality of the sets of variables while retaining the maximum variability of the variance and covariance structure. In other words, PCA tries to explain the structure of a dataset (e.g. the relationships between variables) using a new set of coordinate systems that reduce the number of original variables (Figure 15). 


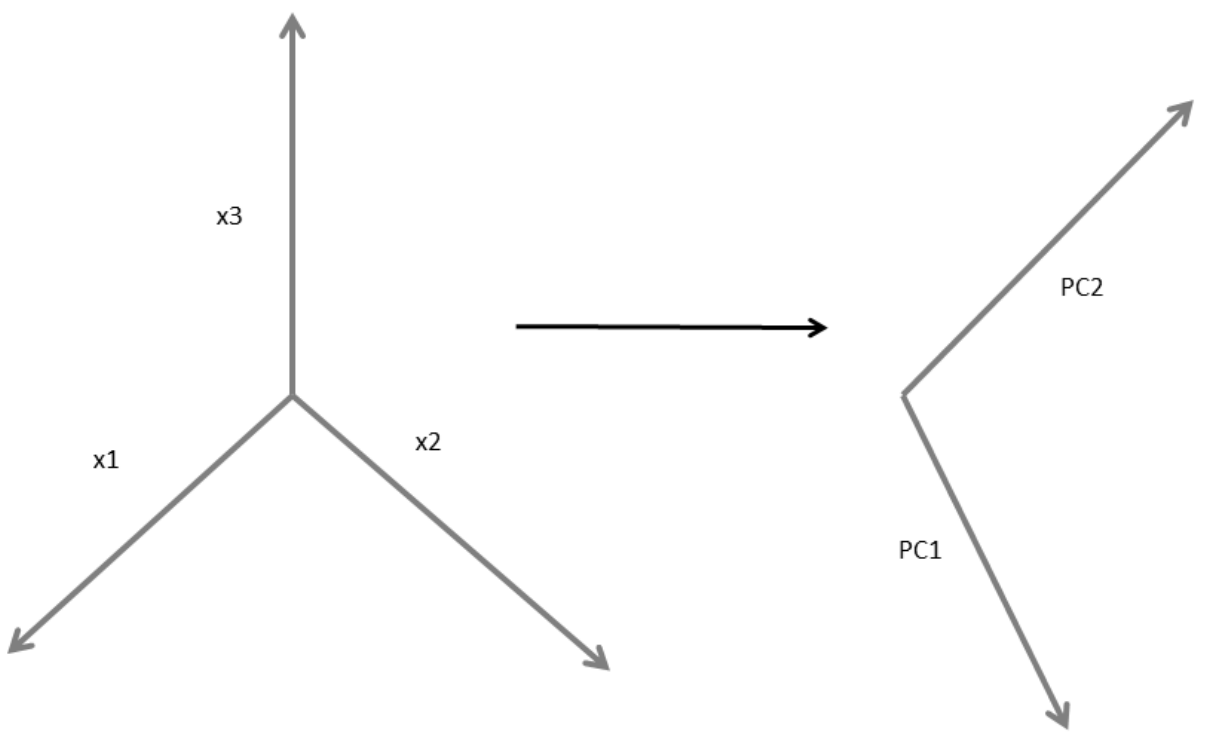

Figure 15. A schematic of a 3-dimensional data set (on the left) represented by a 2-dimensional principal component set (on the right), modified from the manual of the Statistica Software.

The new variables are derived in decreasing order of importance. The first principal component accounts for as much possible of the variation in the original data, and the first component axis (PC1) will stretch out in the direction where there is most variance of the variable space. The second component (PC2) is orthogonal to this axis, and has the direction where there is the second greatest spread of variance orthogonal to the first axis and is uncorrelated with the first component, for the next where there is the third greatest spread of variance, and so on. The derived variables are often used for simplifying later analyses and providing informative plots of the data. The derivation of principal components is extracted from a correlation or a covariance matrix. Eigenvectors and eigenvalues can be calculated, since the matrix is a square (Everett \& Dunn 2001).

STATISTICA NIPALS Algorithm for Partial Least Squares (PLS) models uses a 1-of-N coding scheme for handling categorical dependent variables without imposing an artificial ordering. For a variable with a number $(\mathrm{N})$ of categories, this scheme creates $\mathrm{N}$ dummy variables, and the normalized outputs of the PLS model are interpreted as a class of membership probabilities. For example, if a variable consists of three categories (in our case, non-consumer, intermediate consumer, high consumer), then a natural representation of the variable would be $(1,0,0)(0,1,0)$ and $(0,0,1)$ depending on what the outcome is (see example in Table 11). Dummy variables are also commonly used in regressions and logistic regression analyses, as well as ANOVA when categorical variables have more than two categories. 
Table 11. Example of dummy variables.

\begin{tabular}{lllll}
\hline & & Dummy variables & & \\
Individual number & Consumption group & Non-consumer & Intermediate consumer & High consumer \\
\hline $\mathbf{1}$ & Non-consumer & $\mathbf{1}$ & 0 & 0 \\
$\mathbf{2}$ & Non-consumer & $\mathbf{1}$ & 0 & 0 \\
$\mathbf{3}$ & High consumer & 0 & 0 & $\mathbf{1}$ \\
$\mathbf{4}$ & Intermediate consumer & 0 & $\mathbf{1}$ & 0 \\
$\mathbf{5}$ & High consumer & 0 & 0 & $\mathbf{1}$ \\
$\mathbf{6}$ & Intermediate consumer & $\mathbf{1}$ & 0 & $\mathbf{1}$ \\
\hline
\end{tabular}

Two common methods used for choosing the number of component are Kaiser's and Cattel's criteria (scree test or scree plot). Kaiser's criteria (Kaiser 1960) exclude those principal components whose eigenvalues are less than 1. Cattel's criterion (Cattel 1966) is a graphical method. A scree plot is used to graphically determine the optimal numbers of principal factors (eigenvalues) which can explain most of the variance in the dataset. According to this criterion, we would identify an "elbow" in the curve on the scree plot and retain 3 or 4 principal factors in the example in Figure 16. In this example, four principal factors account for $50 \%$ of the total variance, three principal factors account for $41 \%$ and the first two principal factors can explain about $35 \%$ of the total variance. No more factors to the right of this "elbow" would be extracted. The loading plot in Figure 14 was based on this scree plot.

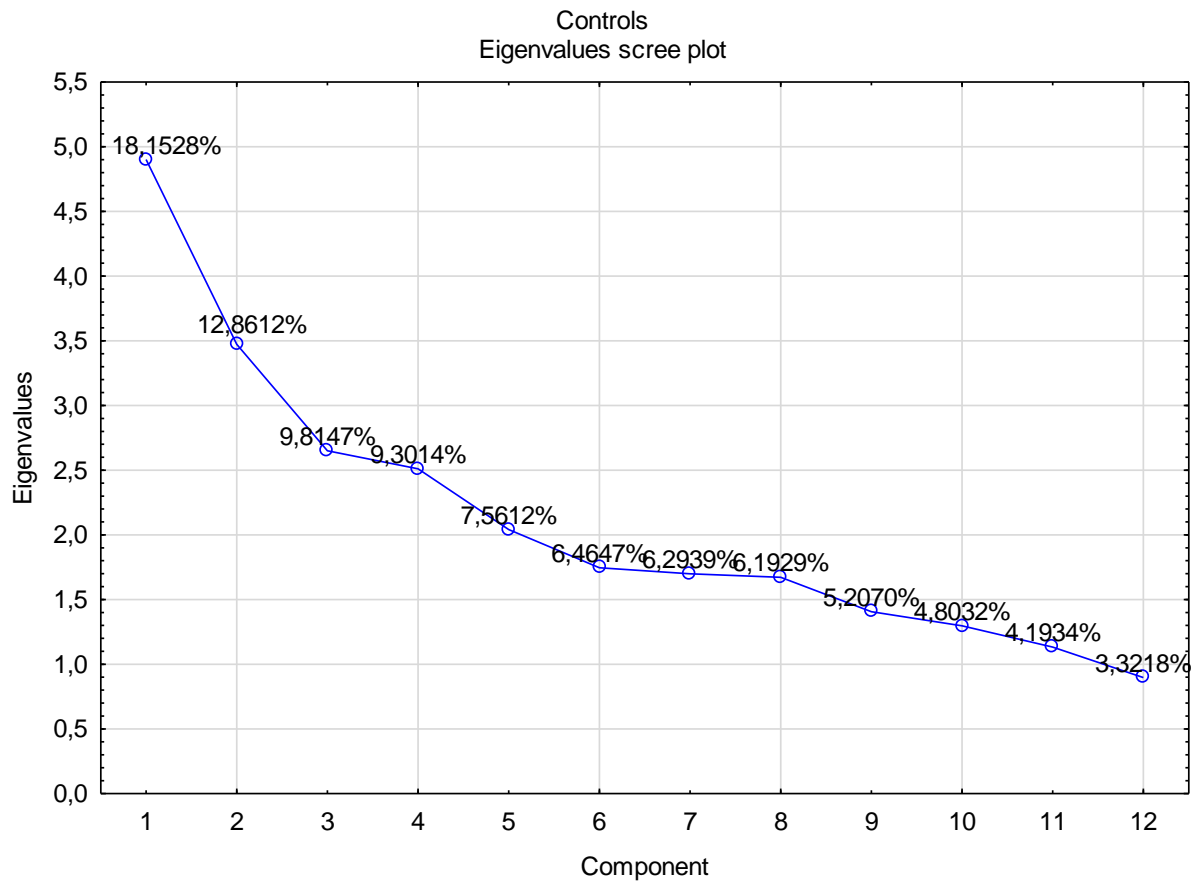

Figure 16. The scree plot (Cattel's criterion), which is used to graphically determine the optimal number of principal factors (eigenvalues) which can explain most of the variance in the dataset in Figure 14. 
In Papers II and III, scatterplots of the principal components have been used to visualize and explore the role of the variables and their contribution to the PCA model. In Figure 14, the variables blood $\mathrm{Cd}$ (B-Cd), active and former smoker, stroke and high consumption of local fish and meat are close together (upper right-hand section), which means that these variables influence the PCA model in similar ways or that they are positively correlated or covariates. The rest of the variables in the upper right-hand section contribute to the model in a similar way and are clustered, but the correlations to the B-Cd are weaker. All variables in the lower left-hand section are negatively correlated with B-Cd. Variables that are far away from the origin influence the PCA model most. The further away a variable is from the origin, the more influential that variable is. In Figure 14, the variables high blood pressure and age have great influence on the PCA model.

Due to the fact that PCA is a hypothesis-generating analysis, further analysis was required. In Papers II and III, main effect ANOVA was used. This is a hypothesis-based test, which is used to determine whether there are any significant differences between the means of three or more independent groups, by comparing variability between groups to variability within groups. The test can only show that at least two groups were statistically significantly different from each other, but cannot show which specific groups were significantly different (Polit \& Beck 2012). To determine which groups differed from each other, a post-hoc test was needed, comparing all possible pairs of groups. In Papers II and III, the post-hoc Bonferroni test was used.

The general aim of this thesis was to evaluate, through epidemiological and toxicological methods, the occurrence of cancer in populations residing in contaminated areas in relation to indirect exposure via the long-term consumption of locally produced food. The epidemiological and toxicological methods and the various statistical methods in the present thesis complemented each other, which led to the interpretation that the data has been simplified. This made it easier to understand the associations between exposure, body burden and risk of cancer. By comparing the results from the various methods, concurrent data could be identified. Depending on choice of method, the conclusion may differ and there is a risk of premature conclusions being drawn. For example, if only an epidemiological method had been used in Paper III, the conclusion may have been that residence in the glassworks area before the age of five years and high consumption of certain local foods (i.e. fish, game meat, chicken, lamb) contributes to an increased cancer risk. If only a toxicological method had been used, the conclusion may have been that high consumers of vegetables, fish, game meat and chicken have elevated concentrations of metals in their blood and there is a potential risk of adverse health effects. In contrast, if only the cancer risk had been evaluated based on the concentration of metals in the blood, no significant associations with increased or decreased cancer risks would have been detected. By comparing all the results, the conclusion was that the associations between the consumption of local food and different types of cancer may reflect a higher exposure in the past, and thus, if the consumption of local food contributes to the risk of acquiring cancer, that contribution is probably lower today than it was previously. 


\subsection{Identified tools for health-risk assessment}

In general, both epidemiological and toxicological data are of great importance in health-risk assessment. An important challenge remains in the need to reconcile epidemiological and toxicological data when the results from the respective methods do not agree. It is difficult to characterize long-term environmental exposure, because an inhabitant in a contaminated area may also be a worker in the industry and may be exposed to several different agents at work, as well as via food intake. It is often difficult to separate the health risk that may be attributed to a single specific exposure since health effects are multifactorial. There is also often a long latent period between exposure and the development of cancer or other disease. Biomarkers are therefore a useful method in the health-risk assessment of a population living in a contaminated area. In both Paper II and Paper III, contaminants in blood and urine were used as biomarkers to assess the exposure to contaminants via locally produced food, together with comprehensive questionnaires (FFQ and a general questionnaire) on lifetime residences, lifetime occupations, smoking habits, anthropometric data, and personal, parental and siblings' medical history, information about current and past food consumption habits during the past 30 years and drinking water source.

Regarding the aim, it was possible to establish associations between exposure sources and contaminant concentrations in blood or urine, as well as for covariates associated with increased cancer risk. It could be concluded that the variables in the questionnaire described differences in exposure to contaminants in the study populations residing in a contaminated area reasonably well. Based on those results, the questionnaire that was developed for this thesis can identify risk categories of populations and could be used as a tool in a health-risk assessment. 


\section{Conclusion}

Despite historically high environmental levels of contaminants in the soil and sediments, current contaminant exposure in the studied populations living in the contaminated areas was similar to or only moderately higher than that of the general population.

No significant associations with increased cancer risk were detected in the highest tertile of metals.

Reported long-term high consumption of certain local foods was associated with higher concentrations of $\mathrm{Cd}$ (vegetarian food) and $\mathrm{Pb}$ (fish, meat) in blood and urine. Long-term high consumption of non-local food from places outside the study areas were not associated with increased concentrations of metals. It was concluded that the questionnaire information about consumption of locally produced food describes differences in food consumption in the study population reasonably well.

An increased risk of cancer was associated with smoking, family history of cancer and obesity. Residing in a contaminated area during the first five years of life was associated with an increased risk of cancer, which may indicate exposure to contaminants in early life. Also, long-term high consumption of local food (fish, chicken, lamb, game meat) was associated with increased risk of various forms of cancer, while high consumption of non-local food was not associated with increased risk of cancer. The associations between habitual consumption of local food and different types of cancer may reflect a higher exposure in the past, and thus, if consumption of local food contributes to the risk of acquiring cancer, that contribution is probably lower today than previously. Furthermore, it cannot be ruled out that other contaminants in the food may contribute to the increased cancer risks observed.

Based on all the results taken together, the questionnaire that was developed for the present thesis can identify risk categories of populations and could be used as a tool in a health-risk assessment. 


\section{Further research}

Preliminary data from the glassworks study showed an association between $\mathrm{Cd}$ concentrations in blood/urine and self-reported osteoporosis, diabetes, stroke, high blood pressure and heart disease. Future research in this area should include:

- Further investigations to determine what health risks are associated with living in a contaminated area.

- Associations between the consumption of local food and risk of osteoporosis, diabetes, stroke, high blood pressure and heart disease.

- Associations between measured concentrations of biomarkers and health effects.

- Experimental studies for increasing the understanding of the mechanism by which metals may affect the risk of adverse health effects.

- Further study of risk communication and risk perception.

In future studies, it will also be evaluated whether measured concentrations of biomarkers in human biological samples correspond with measured concentrations of contaminants in local food, and this could be used to validate the current model and develop exposure scenarios via local food consumption into a probabilistic approach. Such an approach would make it possible to obtain a full range of likely exposures via the consumption or non-consumption of various types of local foods at various concentrations. This may reduce the uncertainty in the risk assessment and lead to suggested improvements to the SEPA computational model. 


\section{Acknowledgements}

Many people have contributed to this thesis in different ways. I would like to express my gratitude to all of them, and especially:

All the people who agreed to participate in the studies.

Marika Berglund, my co-supervisor, who convinced me to be a $\mathrm{PhD}$ student and introduced me to exposure assessment while we were collaborating on studies of high consumers of fish. I am very grateful for your guidance and encouragement and for your valuable support during all these years. Even when you are busy, I have always been able to trust that you will give feedback when I need it. Thank you for believing in me and for being a good friend as well.

Gun Wingren, my first main supervisor, thank you for taking me on as a $\mathrm{PhD}$ student and for your invaluable guidance in epidemiological methods and for all the support you have given me. I really appreciate the way you always give rapid feedback on my texts, your constructive criticism and helpful improvement proposals.

Helen Karlsson, my second main supervisor, thank you for your never waning enthusiasm and for all the support you have given me as well as your valuable input to the final manuscript. Also, thank you for believing in me and for our friendship.

Mats Fredriksson, my second co-supervisor, thank you for your valuable support in statistics and your input to the final manuscript.

Louice Eskilsson, thank you for your never waning enthusiasm, friendship and excellent assistance in sample collection (blood, urine) and for the dispatch of questionnaires and letters.

Anna-Lena Hällsten, thank you for your excellent assistance in several administrative items during all these years and for your long friendship.

Fredrik Nyqvist, thank you for your valuable assistance in the glassworks project and for the collaboration.

Brita Palm, Samira Salihovic, Bert van Bavel, Reza Nosratabadi and Per Leandersson, thank you for your valuable work with analyses of blood and urine.

Inger Nordén Larsson, thank you for your valuable assistance.

Lennart Hellström, thank you for your valuable input in study design and for providing discussions.

Anna Augustsson and Monika Filipsson, thank you for your collaboration and input to the final manuscript.

Bengt Ståhlbom and Christer Tagesson, thank you for your support and for accepting me as a $\mathrm{PhD}$ student. Also, thank you for believing in me. 
I also gratefully acknowledge several individuals at the local administrative boards.

Thanks to all my dear colleagues and friends at the Department of Occupational and Environmental Medicine.

Finally, I express my gratitude to my family, whom I love more than anything: my husband Bernt, my children Helen, Annelie and Fredrik, my grandchild Anton, my sons-in-law Martin and Johan, thank you for your support and love. I also express my gratitude to all my other relations and friends.

Ett speciellt tack till alla som har stöttat mig i min svåra kamp mot sjukdom de senaste åren. Tack vare livräddande åtgärder, operationer, antibiotika, rehabilitering, min egen envishet samt stöd från sjukvården, och inte minst från min älskade familj, nära släkt och vänner, handledare, chef och arbetskamrater har jag lyckats genomföra avhandlingen till slut. 


\section{References}

Andrén P, Shütz A, Vahter M, Attewell R, Johansson L, Willers S, Skerfving S. Environmental exposure to lead and arsenic among children living near a glassworks. Science of the Total Environment 1988.77:25-34.

Angerer J, Ewers U, Wilhelm M. Human biomonitoring: state of the art. International Journal of Hygiene and Environmental Health 2007 May; 210(3-4):201-228. Epub 2007 Mar 21.

Arisawa K, Nakano A, Saito H, Liu XJ, Yokoo M, Soda M, Koba T, Takahashi T, Kinoshita K. Mortality and cancer incidence among a population previous exposed to environmental cadmium. International Archives Occupational Environmental Health. 2001;74(4):255-262.

ATSDR, Agency for Toxic Substances and Disease Registry. Toxicological profile for Polychlorinated Biphenyls (PCBs). November 2000.

ATSDR. Agency for Toxic Substances and Disease Registry. Toxicological profile for lead. 2007.

Augustsson A, Uddh-Söderberg T, Hogmalm J, Filipsson M. Metal uptake by homegrown vegetables: the relative importance in human health risk assessments at contaminated sites. Environmental Research 2015;138:181-190.

Augustsson A, Uddh-Soderberg T, Filipsson M. Helmfrid I, Berglund M, Karlsson H, Hogmalm J, Karlsson A, Alriksson S. Challenges in assessing the health risks of consuming vegetables in metalcontaminated environments. Environment International 2018; 113: 269-280.

Barregård L, Sällsten G, Fagerberg B, Borné Y, Persson M, Hedblad B, et al. Blood cadmium levels and incident cardiovascular events during follow-up in a population-based cohort of Swedish adults: the Malmö diet and cancer study. Environmental Health Perspectives 2016;124(5):594-600.

Bergdahl I, Skerfving S. Biomonitoring of lead exposure: alternatives to blood. Journal of Toxicology and Environmental Health Part A. 2008;71:1235-1243.

Bergqvist C, Öberg M, Appelgren M, Becker W, Aune M. Halldin Ankarberg E, Berglund M, Håkansson H. Exposure to dioxin-like pollutants via different food commodites in Swedish children and young adults. Food and Chemical Toxicology 2008 Nov, 46(11):3360-3367. Doi:

10.1016/j.fct.2008.07.029.Epub 2008 Aug 26.

Bergkvist C, Åkesson A, Glynn A, Michaëlsson K, Rantakokko P, Kiviranta H, Wolk A, Berglund M. Validation of questionnaire-based long-term dietary exposure to polychlorinated biphenyls using biomarkers. Molecular Nutrition and Food Research 2012 Nov;56(11):1748-1754. doi: 10.1002/mnfr.201200196. Epub 2012 Sep 13.

Bergkvist C, Kippler M, Larsson SC, Berglund M, Glynn A, Wolk A, Åkesson A. Dietary exposure to polychlorinated biphenyls is associated with increased risk of stroke in women. Journal Internal Medicine 2014 Sep;276(3):248-259. doi: 10.1111/joim.12194. Epub 2014 Mar 17.

Bergkvist C, Berglund M, Glynn A, Julin B, Wolk A, Åkesson A. Dietary exposure to polychlorinated biphenyls and risk of myocardial infarction in men: a population-based prospective cohort study.

Environment International 2016 Mar;88:9-14. doi: 10.1016/j.envint.2015.11.020. Epub 2015 Dec 12. 
Berglund M, Åkesson A, Nemell B, Vahter M. Intestinal absorption of dietary cadmium in women depends on body iron stores and fibres intake. Environmental Health Perspective 1994 Dec;102(12):1058-1066.

Berglund M, Lindberg AL, Rahman M, Yunus M, Grandér M, Lönnerdal B, Vahter M. Gender and age differences in mixed metal exposure and urinary excretion. Environmental Research 2011 Nov;111(8):1271-1279. doi: 10.1016/j.envres.2011.09.002. Epub 2011 Sep 29.

Bernes C. 1998. Persistent organic pollutants: a Swedish view of an international problem. Swedish Environmental Protection Agency. Stockholm, Sweden. 152 pp.

Bidoli E, Franceschi S, Montella M. Cancer mortality by urbanization and proximity to the sea coast in Campania Region, southern Italy. Rev Tumori. 1998;84460-466.

Bignert A, Nyberg E, Sundqvist KL, Wiberg K. Spatial variation in concentrations and patterns of the $\mathrm{PCDD} / \mathrm{F}$ and dioxin-like-PCB content in herring from the northern Baltic Sea. Journal Environmental Monioring 2007 Jun;9(6):550-6. Epub 2007 May 10.

Bjermo H, Sand S, Nälsén C, Lundh T, Enghardt Barbieri H, Pearson M, Lindroos AK, Jönsson BA, Barregård L, Darnerud PO. Lead, mercury, and cadmium in blood and their relation to diet among Swedish adults. Food Chemistry Toxicology 2013a;57:161-9.

Bjermo H, Darnerud PO, Lignell S, Pearson M, Rantakokko P, Nälsén C, Enghardt Barbieri H, Kiviranta H, Lindroos AK, Glynn A. Fish intake and breastfeeding time are associated with serum concentrations of organochlorines in a Swedish population. Environment International 2013b Jan;51:88-96. Doi: 10.1016/j.envint.2012.10.010. Epub 2012 Nov 28.

Bjerselius R, Halldin Ankarberg E, Kautto A. Bly i viltkött. Del 4 - riskhantering. Rapport från Livsmedelsverket, Rapport nr 18, 2014 (In Swedish).

Björnberg KA, Vahter M, Grawé KP, Berglund M. Methyl mercury exposure in Swedish women with high fish consumption. The Science of the Total Environment 2005 Apr 1;341(1-3):45-52.

Bolt H. Arsenic: an ancient toxicant of continuous public health impact, from Iceman Ötzi until now. Archives of Toxicology 2012 Jun 86:825-830. Doi: 10.1007./s00204-012-0866-7.

Brantsaeter AL, Haugen M, Hagve TA, Aksnes L, Rasmussen SE, Julshamn K, Alexander J, Meltzer HM. Self-reported dietary supplement use is confirmed by biological markers in the Norwegian Mother and Child Cohort Study (MoBa). Annals Nutrition and Metabolism 2007;51(2):146-154. Epub 2007 May 29. Doi: 101159/000103275.

Calderon J, Ortiz-Pe D, Yanez L, Diaz-Barriga F. Human exposure to metals: pathways of exposure, biomarkers of effect and host factors. Ecotoxicology and Environmental Safety. 2003;36:93-105.

Cattel RB. The scree test for the number of factors. Multivariate Behaviour Research, 1966;1:629-637.

County Administrative of Östergötland. Inventory study, Gusum factory, municipality of Valdemarsvik 2003 (In Swedish).

Chen W, Zheng R, Zeng H, Zhang S, He J. Annual report on status of cancer in China, 2011. Chinese Journal of Cancer Research, Vol 27, No 1 February 2015. 2015 Feb;27(1):2-12. Doi: 10.3978/j.issn.1000-9604.2015.01.06. 
Darnerud PO, Atuma S, Aune M, Bjerselius R, Glynn A, Petersson Grawé, Becker W. Dietary intake estimations of organohalogen contaminants (dioxin, PCB, PBDE and chlorinated pesticides, e.g. DDT) based on Swedish market basket data. Food and Chemical Toxicology, 2006;44:1597-1606.

Darnerud P-O, Becker W, Öhrvik V, Kollander B, Sundström B, Strandler HS, Nälsén C, von Malmborg A, Staffas A, Grönholm R, Abramsson Zetterberg L, Thim AM, Brostedt S, Olsen M, Aune M, Bergh A, Haglund M, Fridén U, Näslund M, Glynn A, Eriksson A, Cantillana T, Covaci A, Poma G, Benskin J, Walsh A, Sandblom O, Zuberovic Muratovic A, Yuan B, Sand S, Gadhasson I, Netzel E, Rogne I. Swedish market basket survey 2015: per capita-based analysis of nutrients and toxic compounds in market baskets and assessment of benefit or risk. Swedish National Food Agency 2017. Report 26-2017.

Dziubanek G, Piekut A, Rusin M, Baranowska R, Hajok I. Contamination of food crops grown on soils with elevated heavy metals content. Ecotoxicology and Environmental Safety, 2015;118:183189.

Elert M, Höglund L-O. Huvudstudie Pukebergs Glasbruk, Kemakta konsult AB, Stockholm, Juli, 2012 (In Swedish).

European Commission (EC), CR, 2006. Commission regulation (EC) No 1881/2006 of 19 December 2006 setting maximum levels for certain contaminants in foodstuffs. Replaces Council Regulation 2375/2001 of 29 November 2001 amending Commission Regulation (EC) No 466/2001.

European Commission (EC). Science for Environmental Policy. In Depth Report. Soil Contamination: Impacts on Human Health, September 2013, Issue 5.

European Food Safety Authority (EFSA). Opinion of the Scientific Panel on Contaminants in the Food Chain on request from the Commission related to the presence of non-dioxin-like Polychlorinated Biphenyls (PCB) in feed and food. The EFSA Journal, 2005;284:1-137.

European Food Safety Authority (EFSA). Cadmium in food: scientific opinion of the Panel on Contaminants in the Food Chain. The EFSA Journal, 2009;980:1-139.

European Food Safety Authority (EFSA). Lead dietary exposure in the European population. EFSA Journal, 2012a;10(7):2831.

European Food Safety Authority (EFSA). Update of the monitoring of levels of dioxins and PCBs in food and feed. European Food Safety Authority. EFSA Journal 2012b;10(7):2832.

European Food Safety Authority (EFSA). Scientific Opinion on Lead in Food. Report from EFSA Panel on Contaminants in the Food Chain (CONTAM). 2013 update.

Everitt BS, Dunn G. Applied Multivariate Data Analysis. Second Edition. London: Wiley \& Sons. 2001. ISBN 978-0-4707-1117-0.

Felter SP, Daston GP, Euling SY, Piersma AH, Tassinari MS. Assessment of health risks resulting from early-life exposures: are current chemical toxicity testing protocols and risk assessment methods adequate? Critical reviews in Toxicology, 2015;45:3:219-244, DOI: 10.3109/10408444.2014.993919

Glynn A, Weiderpass E, Granath F, Darnerud PO, Aune M, Atuma S, Bjerselius R. Regionala skillnader i kvinnor, kroppsbelastning av persistenta organiska miljöföroreningar. Livsmedelsverket. 2000. (In Swedish). 
Glynn A, Granath F, Aune M, Atuma S, Darnerud P-O, Bjerselius R, Vaino H, Weiderpass E. Organochlorines in Swedish women: determinants of serum concentrations. Environmental Health Perspectives. 2003;111(3):349-355.

Gordis L. Epidemiology. Fourth edition. Saunders Elsevier. Philadelphia. 2008. ISBN: 978-1-41604002-6.

Göransson P. Miljöundersökningar vid Kosta 1982. Zoofysiologiska institutionen, Uppsala Universitet, 1983 (In Swedish).

Haines DA, Saravanabhavan G, Werry K, Khoury C. An overview of human biomonitoring of environmental chemicals in the Canadian Health Measures Survey: 2007-2019. International Journal of Hygiene Environmental Health. 2017 Mar;220(2 Pt A):13-28. Doi: 10.1016/j.ijheh.2016.08.002. Epub 2016 Aug 24.

Hellström L, Persson B, Brusin L, Petersson Grawé K, Öborn I, Järup L. Cadmium exposure pathways in a population living near a battery plant. Science of the total Environment, 2007;373:447-455.

Helmfrid I, Flodin U, Lindell M, van Bavel B, Anderson U, Karlsson M. Miljögifter i blod hos högkonsumenter av Vätternfisk. Vätternvårdsförbundet, Rapport nr 74. 2003. Sakrapport till Naturvårdsverket. ISSN 1102-3791 (In Swedish).

Helmfrid I, Hällsten A-L, Ståhlbom B, Hellström L. Miljömedicinsk riskbedömning med avseende på konsumtion av analyserade vegetabilier, fisk och kräftor från Gusum. Yrkes- och miljömedicinskt centrum, Linköping 2007 (In Swedish).

Helmfrid I, Salihovic S, van Bavel B, Wingren G., Berglund M. Exposure and body burden of polychlorinated biphenyls (PCB) and metals in a historically contaminated community. Environment International. 2015 Mar;76:41-8., Doi: 10.1016/j.envint 2014.12.004. Epub 2014 Dec 16.

Helmfrid I, Ljunggren S, Nosratabadi R, Augustsson A, Filipsson M, Fredrikson M, Karlsson H, Berglund M. Exposure of metals and PAH through local foods and risk of cancer in a historically contaminated glassworks area. Environment International 131. Epub 2019, Juli 9.

Hennekens CH, Buring JE, Mayrent S. Epidemiology in medicine. First edition, Lippincott Williams and Wilkins, Philadelphia, USA, Library of Congress Catalog Card No. 87-45377, 1987. ISBN 0-31635636-0.

Hughes MF, Beck BD, Chen Y, Lewis AS, Thomas DJ. Arsenic exposure and toxicology: a historical perspective. Toxicological Sciences, 2011;123(2):305-332.

Höglund L, Fanger G, Yesilova H. resultat och tolkningar från undersökningar av 25 glasbruksprojekt och 6 glasbruksåar, Kemakta konsult AB, 2007 (In Swedish).

International Agency for Research on Cancer (IARC) monographs on the evaluation of carcinogenic risks to humans, Suppl 7. 1987.

International Agency for Research on Cancer (IARC) Monographs on the Evaluation of Carcinogenic Risks to Humans. Volume 87. Inorganic and Organic Lead Compounds. 2006.

International Agency for Research on Cancer (IARC) Monographs on the Evaluation of Carcinogenic Risks to Humans. A review of human carcinogens: arsenic, metals, fibres, and dusts. 2012a.

International Agency for Research on Cancer (IARC) Monographs on arsenic and arsenic compounds. $2012 b$. 
International Agency for Research on Cancer (IARC) Monographs on cadmium and cadmium compounds - 100C. 2012c

International Agency for Research on Cancer (IARC) Monographs on the evaluation of carcinogenic risks to humans. Polychlorinated Biphenyls and Polybrominated Biphenyls. Volume 107. 2018.

Iqbal S, Blumethal W, Kennedy C, Fuyuen Y, Pickard S, Flanders WD, Loringer, Kruger K, Caldwell KL, Brown MJ. Hunting with lead: association between blood lead levels and wild game consumption. Environmental Research, 2009;109:952-959.

IMM-report nr 3. Human Health Risk Assessment of Combined Exposures to Chemicals. Karolinska Instiutet 2011, Stockholm

Julin B, Wolk A, Johansson JE, Andersson SO, Andrén O, Åkesson A. Dietary cadmium exposure and prostate cancer incidence: a population-based prospective cohort study. British Journal of Cancer.

2012 Aug 21;107(5):895-900. Doi: 10.1038/bjc.2012.311

Järup L, Åkesson A. Current status of cadmium as an environmental health problem. Toxicology and Applied Pharmacology, 2009;238:201-208.

Kaiser HF. The application of electronic computers to factor analysis. Educational and Psychological Measurement, 1960;20:141-151.

Kippler M, Larsson SC, Berglund M, Glynn A, Wolk A, Åkesson A. Associations of dietary polychlorinated biphenyls and long-chain omega-3 fatty acids with stroke risk. Environment International 2016 Sep;94:706-711. doi: 10.1016/j.envint.2016.07.012. Epub 2016 Jul 26.

Kollander B, Sundström B, Widemo F, Ågren E. Lead in game meat. Part 1: fragments from lead ammunition and chemicals analyses. Report from National Food Agency in Sweden, Report 18, 2014.

Kowalska M, Kulka E, Jarosz W, Kowalski M. The determinants of lead and cadmium blood levels for preschool children from industrially contaminated sites in Poland. International Journal of Occupational Medicine Environment Health. 2018 Jan 15;31(3):351-359. doi:

10.13075/ijomeh.1896.01153. Epub 2017 Oct 26.

Landrigan PJ, Goldman LR. Children's vulnerability to toxic chemicals: a challenge and opportunity to strengthen health and environmental policy. Health Aff (Millwood) 2011 May;30(5):842-850. doi: 10.1377/hlthaff.2011.0151. Epub 2011 May 4.

Larsson S, Bergbeck B, Eklund M, Lohm U. Historical emissions from Swedish crystal-glass production and future scenarios of soil-lead pollution. Environmental Reviews, 1999:53-60.

Larsson SC, Wolk A. Urinary cadmium and mortality from all causes, cancer and cardiovascular disease in the general population: systematic review and meta-analysis of cohort studies. Int $\mathbf{J}$ Epidemiol. 2016;45(3):782-91.

Leith Sly J, Carpenter DO. Special vulnerability of children to environmental exposures. Reviews Environmental Health. 2012;27(4):151-1577. ISSN (Online) 2191-0308, ISSN (Print) 0048-7554, DOI: https://doi-org.e.bibl.liu.se/10.1515/reveh-2012-0024. 
Lignell S, Aune M, Glynn A, Cantillana T, Fridén U. Levels of persistent halogenated organic pollutants (POP) in mother's milk from first time mothers in Uppsala, Sweden: results from year 2012 and temporal trends for the time period 1996-2012. Report to the Swedish EPA (the Health-Related Environmental Monitoring Program). 2014.

Ljunggren SA, Helmfrid I, Salihovic S, van Bavel B, Wingren G, Lindahl M, Karlsson H. Persistent organic pollutants distribution in lipoprotein fractions in relation to cardiovascular disease and cancer. Environment International 2014 Apr;65:93-9. doi: 10.1016/j.envint.2013.12.017. Epub 2014 Jan 25.

Ljunggren SA, Helmfrid I, Norinder U, Fredriksson M, Wingren G, Karlsson H, Lindahl M. Alterations in high-density lipoprotein proteome and function associated with persistent organic pollutants. Environment International 2017 Jan;98:204-211. doi: 10.1016/j.envint.2016.11.008. Epub 2016 Nov 16.

Löf L-O, Thor L. Resa till glaset. Carlssons Bokförlag, Borås, 1986. (In Swedish).

Meltzer HM, Dahl H, Brantsæter AL, Birgisdottir BE, Knutsen HK, Bernhoft A, Oftedal B, Lande US, Alexander J, Haugen M, Ydersbond TA. Consumption of lead-shot cervid meat and blood lead concentrations in a group of adult Norwegians. Environmental Research 2013 Nov;127:29-39. doi: 10.1016/j.envres.2013.08.007. Epub 2013 Oct 9.

Muñus O, Dias OP, Leyton I, Nuñez N, Devesa V, Súñer MA, Vélez D, Montoro R. Vegetables collected in cultivated Anean area of northern Chile: a total and inorganic arsenic contents in raw vegetables. Journal of Agricultural and Food Chemistry 202 Jan 30;50(3):642-647.

National Food Agency (2017). Nätverk vid upptäckt av befolkningsexponering för farliga kemiska ämne. Rapport 22 - 2017 (in Swedish).

Nordberg M \& Nordberg GF. Trace element research: historical and future aspects. Journal of Trace Elements in Medicine and Biology, 2016;38:46-52.

National Research Council (NRC). Human biomonitoring for environmental chemicals. Washington, DC. The National Academies Press. 2006.

Nyberg I, Hällsten A-L, Graff P, Helmfrid I. En uppföljning av hälsoriskbedömning med avseende på konsumtion av analyserade grönsaker, fisk och kräftor från Gusum Linköping. Arbets- och miljömedicin, Landstinget i Östergötland, 2012. (in Swedish).

Nyqvist F, Helmfrid I, Augustsson A, Wingren G. Increased cancer incidence in the local population around metal-contaminated glassworks sites. Journal of Occupation and Environmental Medicine 2017;59:e84-e90. Doi: 10.1097/JOM00000000000001003.

Ocaña-Riola R, Sánchez-Cantalejo C, Rosell J, Sánchez-Cantalejo E, Daponte A. Socio-economic level, farming activities and risk of cancer in small areas of Southern Spain. European Journal of Epidemiology 2004;19(7):643-650.

Ohlsson S-Å. Kalmar läns luftvårdsförbund. Kartläggning av tungmetaller I miljön. Sveriges Geologiska Undersökning. Rapport: GRAP 1-1990, 1990 (In Swedish).

Orloff K, Mistry K, Metcalf S. Biomonitoring for environmental exposures to arsenic. Journal of Toxicology and Environmental Health, Part B. 2017;12(7):509-524. DOI:

$10.1080 / 10937400903358934$. 
Panagos P, Van Liedekerke M, Yigini Y, Montanarella L. Contaminated sites in Europe: review of the current situation based on data collected through a European network. Journal of Environmental and Public Health. 2013;2013:158764. doi: 10.1155/2013/158764. Epub 2013 Jun 16.

Petrie A, Sabin C. Medical Statistics at a Glance. Second edition 2005. London: Blackwell. ISBN: 978-1-4051-2780-6.

Salihovic S, Lampa E, Lindström G, Lind L, Lind M, van Bavel B. Circulating levels of Persistent Organic Pollutants (POPs) among elderly men and women from Sweden: results from the Prospective Investigation of the Vasculature in Uppsala Seniors (PIVUS). Environment International, 2012;44:5967.

Simon, S. Understanding odds ratio and the relative risk. Journal of Andrology, 2001 (JulAug);22(4):533-536.

Skerfving S, Löfmark L, Rentschler G, Lundh T. Kadmiumhalter i blod och urin hos skånska kvinnor 2010 - med jämförelser bakåt till 1999/2000. Rapport från Arbets- och miljömedicin, Lund. 2012 (In Swedish).

Smolders R, Den Hond E, Koppen G, Govarts E, Willems H, Casteleyn L, Kolossa-Gehring M, Fiddicke U, Castaño A, Koch HM, Angerer J, Esteban M, Sepai O, Exley K, Bloemen L, Horvat M, Knudsen LE, Joas A, Joas R, Biot P, Aerts D, Katsonouri A, Hadjipanayis A, Cerna M, Krskova A, Schwedler G, Seiwert M, Nielsen JK, Rudnai P, Közepesy S, Evans DS, Ryan MP, Gutleb AC, Fischer ME, Ligocka D, Jakubowski M, Reis MF, Namorado S, Lupsa IR, Gurzau AE, Halzlova K, Fabianova E, Mazej D, Tratnik Snoj J, Gomez S, González S, Berglund M, Larsson K, Lehmann A, Crettaz P, Schoeters G. Interpreting biomarker data from the COPHES/DEMOCOPHES twin projects: using external exposure data to understand biomarker differences among countries. Environmental Research. 2015 Aug;141:86-95. doi: 10.1016/j.envres.2014.08.016. Epub 2014 Oct 14.

Sperandel S. Understanding logistic regression analysis. Biochemia Medica, 2014;24(1):12-18.

Steenland K, Boffetta P. Lead and cancer in humans: where are we now? American Journal and Industrial Medicine, 2000;38(3):295-9.

Swedish Environmental Protection Agency (SEPA). Glasbrukens miljöproblem. SNV PM 1023, Stockholm, 1978 (In Swedish).

Swedish Environmental Protection Agency (SEPA). Riktvärden för förorenad mark. Modellbeskrivning och vägledning. Rapport 5976. Stockholm, 2009 (In Swedish).

Swedish Environmental Protection Agency (SEPA). Efterbehandlingsåret 2011 - Lägesbeskrivning av arbetet med att avhjälpa sådana föroreningsskador som avses i 10 kapitlet miljöbalken. Skrivelse 2012-04-13, Ärendenr: NV-01257-12. 2012 (In Swedish).

Swedish Environmental Protection Agency (SEPA) (2018). http://www.naturvardsverket.se/Sa-marmiljon/Mark/Fororenade-omraden/ (In Swedish).

Sundström, LJaB. Levels of lead, cadmium, zinc, copper, nickel, chromium, manganese, and cobalt in foods on the Swedish Market, 1983-1990. Journal of Food Composition and Analysis. 1993;6:223241. 
Sundström B, Jorhem L. Bly och kadmium i vegetabilier odlade kring Rönnskärsverken, Skelleftehamn 2006. Livsmedelsverkets rapport nr 20/2008 (In Swedish).

Taylor KW, Novak RF, Anderson HA, Birnbaum LS, Blystone C, Devito M, Jacobs D, Köhrle J, Lee DH, Rylander L, Rignell-Hydbom A, Tornero-Velez R, Turyk ME, Boyles AL, Thayer KA, Lind L. Evaluation of the association between persistent organic pollutants (POPs) and diabetes in epidemiological studies: a national toxicology program workshop review. Environmental Health Perspective. 2013 Jul;121(7):774-783. doi: 10.1289/ehp.1205502. Epub 2013 May 7. Review.

The Swedish Federation of Glazing Contractors. The origin of the glass and its early development (Web information, October 2017). https://www.gbf.se/glasbranschen/inspiration-och-fakta/glasetsursprung-och-dess-tidiga-utveckling (In Swedish).

Thomas LD, Elinder CG, Wolk A, Åkesson A. Dietary cadmium exposure and chronic kidney disease: a population-based prospective cohort study of men and women. International Journal of Hygiene Environmental Health. 2014 Sep;217(7):720-725. doi: 10.1016/j.ijheh.2014.03.001

Törnkvist A, Glynn A, Aune M, Darnerud PO, Halldin Ankarberg E. PCDD/F, PCB, PBDE, HBCD and chlorinated pesticides in Swedish market basket from 2005: levels and dietary intake estimations. Chemosphere, 2011;83:193-199.

Uddh-Söderberg T, Gunnarsson S, Hogmalm J, Lindegård B, Augustsson A. An assessment of health risks associated with arsenic exposure via consumption of vegetables near contaminated glassworks sites. Science of Total Environment, 2015;536:189-197.

Ur Rehman Z, Khan S, Brusseau M, Tahir Shah M. Lead and cadmium contamination and exposure risk assessment via consumption of vegetables grown in agricultural soils of five-selected regions of Pakistan. Chemosphere, 2017;168:1589-1596.

US Environmental Protection Agency (EPA). Child-Specific Exposure factors Handbook, EPA/600/P00/002B; National Center for Environmental Assessment; Washington; DC, 2002, 448 pp.

van der Berg M, Kypke K, Kotz A, Tritscher A, Yong Lee S, Magulova K, Fiedler H, Malisch R. WHO/UNEP global surveys of PCDDs, PCDFs, PCBs and DDTs in human milk and benefit-risk evaluation of breastfeeding. Archives of Toxicology, 2017 Jan; 91:83-96 Doi; 10.1007/s00204-0161802-z. E-pub 2016 Jul 20.

Wenemark M, Hollman Frissman G, Svensson T, Kristensson M. Respondent satisfaction and respondent burden among differently motivated participants in health-related survey. Sage Journals, 2010;22:1-14.

Wennberg M, Lundh T, Nilsson Sommar J, Bergdahl I.. Time trends of lead and cadmium in the adult population of Northern Sweden 1990-2014. Yrkes- och miljömedicin i Umeå. 2015.

Wennberg M, Bergdahl I, Ståhl T. Persistenta organiska miljöföroreningars halter i plasma i relation till kostfaktorer av betydelse för diabetesrisk. Institutionen för folkhälsa och klinisk medicin. Yrkesoch miljömedicin i Umeå Universitet, 2012 (In Swedish).

Wilde K, Forsgard N, Hovgard A, Sällsten G. 2016. Kadmiumexponering och markör för njurpåverkan hos yngre och medelålders kvinnor i Västsverige 2015 (In Swedish). 
Wingren G. Epidemiologic studies of health hazards related to the Swedish art glass industry. Linköping University Medical Dissertations No. 346. Department of Occupational Medicine, 1991.

Wingren G, Axelson O. Cluster of brain cancer as related to complex mixtures of trace elements in the art glass industry, Scandinavian Journal of Work, environmental Health 1992;18:85.

World Health Organisation (WHO). Arsenic and arsenic compounds (Environmental Health Criteria 224). $2^{\text {nd }}$ ed. Geneva, World Health Organization. Fact sheet, International Programme on Chemical Safety. 2001.

World Health Organisation (WHO). Health risks of heavy metals from long-range transboundary air pollution 2007; Regional office for Europe, Denmark, ISBN 9789289071796.

World Health Organisation (WHO). Exposure to cadmium: A major public health concern. Preventing disease through healthy environments, fact sheet, Switzerland, 2010

World Health Organisation (WHO). Lead poison and health. Fact sheet. 2016.

World Health Organisation, WHO/UNEP global surveys of PCDDs, PCDFs, PCBs and DDTs in human milk and benefit-risk evaluation of breastfeeding. Archives of Toxicology, 2017;91:83-96.

Yousaf B, Liu G, Wang R, Imtiaz M, Shahid Rizwan M, Zia-ur-Rehman M, Mujtaba MA, Niu Z. Bioavailability evaluation, uptake of heavy metals and potential health risks via dietary exposure in urban-industrial areas. Environmental Science and Pollution Research international, 2016;23:2244322453.

Åkerström M, Barregård L, Lundh T, Sällsten G. The relationship between cadmium in kidney and cadmium in urine and blood in an environmentally exposed population. Toxicology and Applied Pharmacology, 2013 May 1;268(3):268-293. Doi: 10. 1016/j.taap.2013.02.009. Epub 3013 Feb 27.

Åkesson A, Barregård L, Bergdahl IA, Nordberg GF, Nordberg M, Skerfving S. Non-renal effects and the risk assessment of environmental cadmium exposure. Environmental Health Perspective.

2014;122(5):431-438. Doi: 10. 1289/ehp. 1307110. Epub 2014 Feb 25. 




\section{Papers}

The papers associated with this thesis have been removed for copyright reasons. For more details about these see:

http://urn.kb.se/resolve?urn=urn:nbn:se:liu:diva-160957 


$$
\frac{40}{40}
$$

\section{FACULTY OF MEDICINE ANB HEALTH SCIENCES}

Linköping University medical dissertations; No. 1699, 2019

occupational and Environmental Medicine cehter and

Department of Clinical and ExperimentalMedicine

Linköping University

SE-58183 Linkoping, Sweden

ww.liu.se

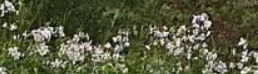

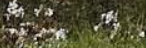

s.

min. 